\title{
Un cuaderno de versos manuscritos en español de ca. 1550 en el Archivo Histórico de Protocolos de Barcelona
}

\author{
Kenneth Brown \\ University of Calgary \\ brownk@ucalgary.ca \\ Gemma García-San Román \\ University of Calgary \\ rggarcia@ucalgary.ca
}

Recepción: 26/04/2014, Aceptación: 16/10/2014, Publicación: 17/12/2014

\begin{abstract}
Resumen
El presente es un estudio largo, en varias partes, que se centra en un cuaderno de versos de mediados del siglo xvi en lengua española que se ha exhumado en el Archivo Histórico de Protocolos de la ciudad de Barcelona. El manuscrito contiene obras de Garcilaso, Cetina, Diego Hurtado de Mendoza, Montemayor y Oropesa, además de muchos anónimos. En total el cuaderno contiene veintiocho poemas, algunos de ellos totalmente nuevos, en el sentido de que nunca han sido catalogados en una base de datos académica. Son dos las vertientes genéricas del cuaderno: cuatro romances tanto bíblicos como mitológicos, seguidos de una veintena de versos al itálico modo y de temática amorosa. Así, este pequeño cancionero es representativo tanto de la creatividad espańola castiza como de la nueva influencia petrarquesca que invadía amable pero decididamente la Península Ibérica durante los primeros decenios del siglo Xvi. Nuestro estudio incluye una introducción, seguida de una edición crítica del manuscrito, más una reproducción fotográfica en facsímil del texto. Se incluye luego una transcripción de otros romances bíblicos que comparten cierta relación temática con los romances veterotestamentarios del cuaderno.
\end{abstract}

1. Proyecto de investigación parcialmente subvencionado gracias a una University of Calgary Faculty Career Development Award otorgada en el año 2006. Las siglas empleadas en el presente estudio son las siguientes: AHPB (= Arxiu Històric de Protocols de Barcelona), BNC (= Biblioteca Nacional de Catalunya), BNE (=Biblioteca Nacional de España, Madrid), BNP (= Bibliothèque Nationale, Paris), BUB (= Biblioteca de la Universitat de Barcelona), CORDE (= Real Academia Española, Corpus Diacrónico del Español), EJ (=Enciclopaedia Judaica), DA (= Real Academia Española, Diccionario de autoridades), HSA (= Hispanic Society of America), UAM (= Universidad Autónoma de Madrid, Edad de Oro), Catálogo de manuscritos de la Biblioteca Nacional con poesía en castellano de los siglos XVI y XVII. 


\title{
Palabras clave
}

Garcilaso de la Vega; Diego Hurtado de Mendoza; Gutierre de Cetina; Jorge de Montemayor; Oropesa; cuaderno de versos; petrarquismo; romances bíblicos; sonetos; Barcelona; Archivo Histórico de Protocolos de Barcelona

\begin{abstract}
A Mid-Sixteenth-Century Spanish Poetic Anthology, a Manuscript Exhumed in Barcelona's Notarial Archives.

This is a multi-part study centering on a hitherto unknown-to-exist, mid-sixteenth-century Spanish poetic anthology exhumed in Barcelona's Notarial Archives. The ms. includes poems authored by Garcilaso, Cetina, Diego Hurtado de Mendoza, Montemayor, and Oropesa. Also, many of the twenty-eight poems included herein are anonymous, and several entirely new, in the sense that their first verses have never been catalogued in academic databases. The collection includes two distinct series of poems: biblical ballads and a long mythological work, as well as numerous Italianate-verse sonnets and a poem in tercets, characteristic of the fresh wave of Petrarchism transforming the discourse of literature of the Iberian Peninsula at the time. The study includes an introductory essay, followed by a critical edition of the manuscript, and a photographic facsimile of the original. This is followed by a series of biblical ballads in Spanish.
\end{abstract}

\section{Keywords}

Garcilaso de la Vega; Diego Hurtado de Mendoza; Gutierre de Cetina; Jorge de Montemayor; Oropesa; book of poems; Petrarchism; biblical ballads; sonnets; Barcelona; Barcelona's Notarial Archives

\section{Introducción}

Entre los 'centenares de miles de papeles privados y públicos, personales, contraturales, administrativos, de contabilidad, etc.' que posee y guarda el Archivo Histórico de Protocolos de Barcelona ${ }^{2}$, vinculado con el Colegio de Notarios de Cataluña ${ }^{3}$, «en sus casi 9.000 metros lineales de estanterías» se encuentra en la colección de «Varios» (i.e. "Varia») un cuaderno de versos de confección de me-

2. En catalán, Arxiu Històric de Protocols de Barcelona.

3. En catalán, Collegi de Notaris de Catalunya. 
diados del siglo xvi cuyo contenido son veintiocho poemas en español. ${ }^{4}$ Los versos son representativos del mejor estro creativo y secular, laico, de la etapa inicial del «Primer Siglo de Oro», de acuerdo con el criterio normativo establecido en 1970 por Antonio Gallego Morell y compartido por otros distinguidos filólogos posteriormente ${ }^{5}$ : fenómeno habido a partir del tercer decenio de la centuria y que se extiende desde la musa de Garcilaso hasta e inclusive la obra madura de poetas como Don Diego de Hurtado y Mendoza (1503-1575), Jorge de Montemayor (h. 1520/1525-1561) y Gutierre de Cetina (1514-h. 1554). Destacan en él tres romances en rima consonántica y de temática veterotestamentaria, que por esta razón puramente técnica en la historia de la métrica poética en español, acaso deberá la confección original de ellos retrasarse cronológicamente de ca. 1550 más bien un par de decenios ${ }^{6}$. En efecto, dichos romances circulaban impresos casi en orden idéntico pero con comentario histórico a la vez que exegético, con tendencia moral a la cristiana, en el Libro de los quarenta cantos (Sevilla 1550), del enigmático humanista heterodoxo Alonso de Fuentes, su supuesto recopilador y también comentarista, oriundo de Sevilla ${ }^{7}$. El Cancionero

4. Según se lee en el folleto informativo que prepara la entidad: Col·legi de Notaris, c/Notariat, 4, 08001 Barcelona. Ver Cazeneuve (2011: 105, 106, 110-111 y 123).

5. Gallego Morell (1970). Ver asimismo Prieto (1984), quien sigue un reparto semejante, el que empieza con la obra de Boscán y finaliza con la de Aldana; y Terry (1965), quien empieza con Garci Sánchez de Badajoz (1460?-1526?), e incluye a Pedro Manuel Ximénez de Urrea (1486?1529?), Juan Álvarez Gato (ca. 1440-1509, Fray Ambrosio Montesino (m. ca. 1513), Juan del Encina (1468-1529?), Gil Vicente (1465?-1536?), Juan Fernández de Heredia (1480/1485-1549), Cristóbal de Castillejo (1492?-1550), Juan Boscán / Joan Boscà (1474?-1542), Sá de Miranda (1481-1558), Garcilaso (1501-1536), Diego Hurtado de Mendoza (1503-1575), Sebastián de Horozco (1510?-1580), Santa Teresa (1515-1582), Hernando de Acuña (1518-1580?), Gutierre de Cetina (1514/1517-1554/1557), Gregorio Silvestre (1520-1569), Juan/Joan de Timoneda (m. 1583), Jorge de Montemayor (1520?-1561) y Luis de Camóes (1524-1579). Blecua (1982 y 1984), I, «Renacimiento», comienza con un romance anón., y luego incluye a Francisco López de Villalobos (1473-1549), Díaz de Frexenal (m. 1560), Antonio de Soria (época de Boscán), Boscán, Juan Fernández de Heredia, Luis/Lluís Milán (m. 1564?), Sá de Miranda, Castillejo, Juan Hurtado de Mendoza (1496?-1560?), Garcilaso, Diego Hurtado de Mendoza, Horozco, Cristóbal Cabrera (1513-1597), Gonzalo de Figueroa (ca. 1550), Don Juan Coloma (m. 1586/1587), Jerónimo de Urrea (ca. 1550-1560), Núñez de Reinoso (ca. 1550), Santa Teresa, Antonio de Villegas (m. 1550), Lorenzo de Sepúlveda (ca. 1550), Alonso de Fuentes (1515-m. 1567), Francisco de Guzmán (ca. 1560), Acuña, Cetina, Juan de Iranzo (ca. 1560), Silvestre, Montemayor, Juan Farfán (ca. 1560), Juan Sánchez Burguillos (1520?-1575), Pedro de Andrada Caminha (1520?-1589), Diego de Fuentes (1525?-1575?), Diego Ramírez Pagán (1524?-?) y Camões. Ver asimismo Guillén (1988).

6. Ver Pedraza y Rodríguez (1980), apartado «La lírica en la primera mitad del siglo. Garcilaso y la incorporación de los metros italianos», 333-383, aquí la 339: «Los poetas cortesanos al escribir romances tendieron a eliminar la asonancia en favor de la rima consonante. Esto condenaba al poema a una monotonía y a unas trabas expresivas que sólo un poeta de la sensibilidad de Juan del Encina podía superar».

7. Fuentes (1550). Los tres romances se reproducen entre los sigs. ff.: «Perseguido anda David», Canto quinto de la primera parte, xxii ${ }^{\mathrm{r}}$-xxiii ${ }^{\mathrm{r}}$, «A Joseph nińo pequeño» [sic], Primera parte Canto tercero, ff. xiiiir ${ }^{\mathrm{r}} \mathrm{xv}^{\mathrm{r}}$, $\mathrm{y}$ «Durmiendo estaba faraón», Canto quarto de la primera parte, fol. 
de romances nuevamente sacados de historias antiguas de la crónica de España, del también "vezino de Seuilla» Lorenzo de Sepúlveda, pero únicamente en la edición medinaense de $1576^{8}$, contiene romances bíblicos temáticamente afines pero no idénticos a los de nuestro cancionero.

El cuarto romance, del mito de Píramo y Tisbe, en el que predomina la rima consonántica en competencia con la asonántica, se atribuye a un tal Oropesa. A la vez, aparece este mismo poema en versión arquetípica pero con numerosas variantes significativas en el antes mencionado Cancionero de romances (Medina de Campo 1576), en el que no consta dicha atribución de autoría (Lorenzo de Sepúlveda, ff. $214 \mathrm{v}-218 \mathrm{v}$ ). Por razones de pura coincidencia cronológica, onomástica y de oficio, empero, la autoría puede que apunte al humanista Martín Laso o Lasso de Oropesa (ca. 1500- ¿?), traductor de La Farsalia de Lucano (Madrid [?] 1530 y 1588; Amberes, 1540, 1551 y 1585; Lisboa, 1541; y Valladolid, 1544)9.

También ahí se encuentran numerosos sonetos de amor no correspondido, desesperado o fracasado, un par de quintillas ligeras y hasta una epístola de temática bucólica y amorosa en tercetos encadenados. La temática erótica, a la vez seria que ora burlona, prevalece en estas poesías. Se incluye en el cuaderno un soneto célebre del ingenio toledano Garcilaso de la Vega ${ }^{10}$. Además, contiene una

xviir $^{r-v}$. Cito de esta ed., ejemplar de la BNP, sign. RES- YG-78. Hay un ejemplar de la Bayerische Staatsbibliothek, sign. P.o. hisp Fuentes 85, en consulta en línea en la sig. dirección electrónica: www.bsb-muenchen.de. Fuentes provee numerosas indicaciones en el texto de ser alumbrado o de enseñar afición al movimiento alumbradista. He aquí algunas indicaciones de los comentarios heterodoxos de este recopilador y exégeta sevillano: (fol. 22v) «los justos suelen ser affligidos [sic] y perseguidos», (fol. 30v) «el verdadero Christiano que quiere hablar y communicar y gozar de Dios, a lo interior», (fol. 32r) «Y alumbrarte ha Christo ... que Christo te dé lumbre de gracia», (52v) "que pues que Dios te ha alumbrado», (fol. $77 \mathrm{v}$ ) «como deuemos de procurar lo interior, que es el espíritu para contemplar», (fol. 84r) «...y aunque por ser christiano viejo holgara passar por ello. Pero no dexaré de dezir, del que en nuestra ciudad hizo el quemadero: que oy día está, que fue el primero, que en él quemaron en lo qual pareció: no ser buena su intención: y por esto dixo el ecclesiástico Capítulo tercero. Quien haze hoyo, caerá en él. Quien pusiere la piedra, para en que tropiece su próximo, ella le offenderá: y quien pone lazo a otro, pereserá en él.»; (fol. 88r) «Y nosotros siendo tan alumbrados, y guiados por la ley Euangélica, seamos tan remissos: en exercitar las virtudes...», (fol. 90r) «que al que las busca, luego nuestro señor le alumbra, porque la condición de nuestro dios es alumbrar, y fauorecer, y aún parece a quien lo busca». Eds. posteriores son de Zaragoza, J. Millán 1564; Alcalá de Henares, Juan Gracián 1557 y 1587; y Granada, por Antonio de Lebrixa [Elio Antonio de Nebrija] y García de Briones, 1563.

8. Sepúlveda (1576). Ejemplar de la Stadtbibliothek Ulm, Alemania, sign. Schad 6906. Quisiera aprovechar la ocasión para expresar mi gratitud más sincera al Sr. Alexander Rostock y a la Sra. Dorothea Schuch, ambos del equipo bibliotecario de la mencionada Biblioteca de la ciudad de Ulm, por proveerme una copia fotográfica digital de este impreso tan raro.

9. Marco Anneo Lucano, autor, y Martín Lasso de Oropesa (1530); idem, con editor e impresor Joannes Crinitus, Amberes, 1540; idem, con Luis Rodrigues, editor e impresor, Lisboa, 1541. Para suplementar estos detalles bibliográficos véase, de la Universidad Carlos III de Madrid, bajo el nombre de Lucio Anneo Séneca, a Martín Laso de Oropesa, página electrónica en consulta, http://www.uc3m.es.

10. Cfr. Garcilaso de la Vega, (1995), CIII-CIV; Boscán,1991, lxxviii; y Rivers, 2010, 23-24 y 43 -44. 
serie de versos conocidos y hasta varios poemas desconocidos e inéditos de don Diego Hurtado de Mendoza; los testimonios antiguos tienen la ventaja de ayudar a reconstruir e idear con mayor precisión la transmisión de su obra "completa" ${ }^{11}$. Ahí hay por lo menos tres sonetos de Cetina y dos de Montemayor. Incluso enriquece el contenido un soneto anónimo de tono levemente satírico en español que va dirigido a una señora de la nobleza barcelonesa al meterse monja.

El cuaderno pequeño, así con sus veintiocho poemas, algunos de ellos fragmentarios, contiene un número apreciable de rimas jamás anteriormente impresas, es decir "nuevas» o sea novedosas, que se sepa, en la historiografía literaria de la Edad Áurea y la crítica textual aplicada. Incluye asimismo testimonios que pudieran ser los más tempranos que haya. Como tal, el hallazgo y su consiguiente edición nuestra y publicación se espera aporte una contribución de indudable interés con que abastecer el corpus en español, ya formidable, de obras poéticas áureas de la primera mitad del siglo XvI.

\section{Descripción codicológica del manuscrito ${ }^{12}$}

En su Índice cronológico alfabético [de los protocolos, manuales y demás documentos consistentes en la Biblioteca del Colegio Notarial de Barcelona] (1950-1959, III, 426), el renombrado bibliotecario e historiador barcelonés Josep Maria Madurell i Marimón ya había dedicado a nuestro cuaderno un mínimo de descriptores: «Pliego de versos», «16ff. i $+15 \mathrm{ff} .{ }^{13}$. Actualmente el cartapacio que contiene el cuaderno se designa mediante el número 29, Lligall - 1, en lengua catalana (o 'L[e]g[ajo]' - 1, en la española), la que era y aún es una designación provisional, además de la rúbrica lacónica en español, «Antiguo Libreros e impresores versos $n^{\circ}$ 29». El dicho cartapacio de "varios» contiene también las siguientes obras literarias manuscritas e impresas muy breves, todas ellas facticias y representativas tanto del bajo medievo como del renacimiento humanista y el barroco: Varia b1. Fragmentos manuscritos a nombre de Bartolomé del Bosch: a. Fragmento de versos; b. Fragmento de una comedia [i.e. commedia] en italiano, atto terzo, impreso, fecha 1487; c. [Fragmento, en neo-latín] «Libero vintus de Prosodia, Hoc est silabarum. Quantita. Te Acce Intupedibus et metris sillabe. Siglo XVII.»; Varia b2. Poesía amorosa [en catalán], siglo $\mathrm{xV}+$ su transcripción actualizada; Varia b3. "Jornada primera de la Comedia famosa dels [sic] triunfos de San Miguel,, impreso, 1 fol. r-v, en español. Ahora bien, en el fol. $2 r$ se lee en letra manuscrita en catalán y luego latín, «Dich jo franc[es]ch Cuyas pages Die Lunes Septima 9bris 1692» ('Digo yo, Francesc Cuyàs, campesino, lunes, 2 septiembre 1692'), seguido de anotaciones

11. Se entiende el adjetivo "completa» como una designación siempre hipotética.

12. Me guío por Pere Bohigas (1973-74), 93-99.

13. Madurell Marimón [1950-] (1959), 426, «Pliego de versos»; 16 ff. i + 15 ff., sin página con título. 
relacionadas con el pago de una cuenta; Varia b4. En catalán, un pequeño fragmento de poesía en formato manuscrito sin fecha, titulado Cançoner meu. Tales documentos son todos ellos sin vinculación genética alguna entre sí, ni siquiera con el pequeño cancionero en español que los acompaña.

Es posible que el cuaderno de versos áureos quedara desconocido y/o ignorado hasta la fecha por su descripción codicológica poco intrigante o porque, tal como nos enseña Xavier Casaneuve i Descarrega en un ensayo reciente, el Archivo Histórico de Protocolos de Barcelona por regla general lamentablemente no es un lugar frecuentado ni por filólogos ni por lingüistas (Xavier Casaneuve i Descarrega, 148n.11). Además, el estado defectuoso del manuscrito, asunto abordado infra, habrá contribuido ciertamente a su relegación o a la ignorancia total del mismo.

Una descripción codicológica bastante más completa del cuaderno de versos que la ofrecida por Madurell, es la ficha bibliográfica digital de la «Base de dades de Manuscrits Catalans de l'Època Moderna", http://mcem.iec.cat/veure. asp?id_manuscrits=544, correspondiente al ms. objeto de nuestro estudio:

\section{Id MCEM: 715}

Ciutat: Barcelona. Biblioteca / Arxiu: Arxiu Històric de Protocols. Signatura: Varria, 29, llig. 1. Signatures antigues: 248 (1). Data: XV ex. - XVI. Llengua: Català, castellà. Suport: Paper. Mides: 255 x 175 mm (fragment descrit). Folis: 22 f. s.n. , excepte el plec 2: f. 1-11 en llapis. Copista: Diverses mans. Enquadernació: Sense relligar. Llom: «Varia. Pliego de Versos». Procedència: ... Estat de conservació: ... Ornamentació: ... Matèries: Poesia. Autor: Gutierre de Cetina (1514/17-c. 1557). Diego Hurtado de Mendoza (1503/4-1575). Jorge de Montemayor (c. 1520- c. 1561). Garcilaso de la Vega (1501?-1536). Títol: [Fragments poètics]. Contingut: [1] F. [1-2] [Fragment final d'una cançó (final del s. Xv)]. Coberta: «Varia. Pliego de versos. Siglos XvI-XVII». F. [1] Inc.: «[...] L'ora que yo us puch mirar» [2 cobles de 8 v. + tornada de 4]. F. [2] [Transcripció moderna del fragment]. [2] F. 1 - [15] [Poemes en castellà (s. XVI)]. A la coberta: «Libreros e impresores. Versos». [2a] F. 1-2 [Fragment acèfal d'un romanç sobre Saül i Samuel (en castellà)]. Inc.: «[...] muy cerca de adonde estaba». [2b] F. 2-4 [Romanç]. "Otro». Inc.: «[A] Josep niño y pequeño». [2c] F. 4-5 [Romanç]. «Otro». Inc. «Durmiendo estava Faraón». [2d] F. 6-8 [Romanç]. «Otro. de Oropesa». Inc. "Allá en la gran Babilonia». [2e] F. 8v [Garcilaso de la Vega]. Soneto. Inc.: «Estoi contino en lágrimas bañado». [2f] F. 8v-9 [Gutierre de Cetina]. «Soneto». Inc. «Leandro, que de amor en fuego ardía». [2g] F. 9: «Soneto». Inc.: «Hero, que ningún día rreposava». [2h] F. 9-9v: «Soneto». Inc. "Leandro, que en amores no se halla». [2i] F. 9v: «Soneto». Inc.: «La gran absencia a Ero le causava». [2j] F. 9v: «Soneto». Inc. "¿Quién de cristal el coraçón tuviera» [falten els 4 v. finals]. [2k] F. 10: «Soneto». Inc.: «¿Quándo será aquel día venturoso». [2l] F. 10-10v: [Diego Hurtado de Mendoza]. «Soneto a doña Marina [corr. sobre María] de Aragón». Inc.: «En la fuente [ms. fuerte] más clara y apartada».

[2m] F. 10v: [Diego Hurtado de Mendoza]. «Soneto». Inc.: «Gasto [ms. basto] la vida en males y amor creçe». [2n] F. 10v-11: [Diego Hurtado de Mendoza]. «Soneto». Inc.: «Buelve el çielo y el tiempo huye y calla». [2o] F. 11: [Diego Hurtado de Mendoza]. «Soneto». Inc. «Agora en la dulce sciençia enbravecido». [2p] F. 11-11v: «Soneto». Inc. «Si pudiese bastar el bien amaros». [2q] F. 11v: [Gutierre de Cetina]. 
«Soneto de don Diego de Mendoça a un rretrato de una dama». Inc. «Pinzel divino, venturosa mano».

[2r] F. 11v-12: «Soneto del mismo a una labradora». Inc. "En un rrústico vestir y gran baxesa». [2s] F. 12: [Jorge de Montemayor]. "Soneto del mismo». Inc.: "Los ojos no pecaron en miraros». [2t] F. 12-12v: [Jorge de Montemayor]. "Soneto». Inc.: "O yngrato amor, ¿quién no te conoçiese?». [2u] F. 12v: [Diego Hurtado de Mendoza]. «Soneto». Inc.: «Mis ojos de llorar están cansados». [2v] F. 12v: «Soneto a una dama de palacio que se quiso meter monja en Santa Catalina y tornóse a palaçio». Inc.: « ¿Cuán mal parece al mundo un movimiento». [2w] F. 13-13v: «Soneto». Inc.: «Ero de una fatiga congoxosa».

[2x] F. 13v: «Soneto». Inc.: «Hero con amorosas lágrimas llorava». [2y] F. 13v-14: «Soneto». Inc. «Estando naturaleza deseosa». [2z] F. 14-14v: [Pedro de Guzmán?]. «Epístola». Inc.: «Salud Libe[a] a Meliso envía» [s’interromp al final]. [2aa] F. 15: Inc. «Dama de lindo valor». [2bb] F. 15: «Respuesta de la dama». Inc.: «Soys inportuno, señor». [3] F. [1] [Fragment poètic procedent d'un manual del notari Bartomeu del Bosc, menor]. A la coberta: «Varia. Bartolomé del Bosch. Fragmento de versos». F. [1] Inc.: «[...] la lengua [...]. / [H]i per què hun gra da mil». Al marge, en llapis: «Bartolomé del Bosch, caja 12, man. 2. años 1406-84. Plana: 29-8-1487. Observacions: Inclosos en un recull factici de fragments de poemes i textos dramàtics, alguns extrets de registres notarials (s. XV-XVII). [2b-c] es llegeixen als Quarenta cantos de diversas y peregrinas historias declarados y moralizados por el magnífico caballero don Alonso de Fuentes (1a ed.: Sevilla. Dominico de Robertis. 1550; citat per Rodríguez-Mońino 1973-1978: I, 305). L’epístola [2z] es copia en alguns cançoners manuscrits dels s. XVI-XVII, i en un cas és atribuïda a Garcilaso de la Vega: modernament s'ha avançat la hipòtesi que l'autor sigui Pedro de Guzmán, personatge que hom ha volgut identificar amb un dels fills de l'anterior (veg. Marino 1985). [3] prové d'un protocol del notari Bartomeu del Bosc (AHPB, 248/2 [=Bartomeu del Bosc, menor. Secundum manuale, 1486-1489]), documentat entre 1483 i 1495 (veg. Madurell i Marimon 1950-1959: I, 63-65, on no es distingeix del seu homònim, major; Cases 2001-2010: I, 363).

Entre [1] i [2], fragment de la comèdia Los triunfos de san Miguel, d'Álvaro Cubillo de Aragón, amb un albarà del copista datat a Barcelona el 7 de novembre de 1672; l'obra va ser editada a Á. Cubillo de Aragón. El enano de las Musas. Comedias y obras diversas. Madrid: María de Quiñones, 1654, p. 101-138. Al final del recull que descrivim hi ha un f. imprès s. n. que conté un fragment d'una peça dramática en edició bilingüe castellà-italià (s. XVII). [MTS]

Bibliografia: ED.: [2e] Boscà; Vega 1995: 628. [2f, 2q] Cetina 1990: 192, 128. [2k] Cancionero 1993: 274. [2l-o], [2u] Hurtado de Mendoza, D. 1989: 74-76, 311. [2s-t] Montemayor 1932: 45, 59. [2s] Cf. Cancionero 1989: 29, 189. [2z] Id.: 50-53, 195. [2aa-bb] Flor de enamorados 1562: 45-45v. // DESCR.: Madurell 1950-1959: III, 426. Repertori 1474-1620: III. 395-398. // EST.: [2z] Marino 1985, [2aa-bb] Romeu i Figueras 1972. Cf. Timoneda 1983.

Las incorrecciones incluidas en la ficha son la falta de designación de lugar de procedencia (i.e. Barcelona), la de comentar el estado de conservación (i.e. lamentable), la de la ornamentación gráfica (asunto abordado en detalle infra y que se puede apreciar en la reproducción facsímil del cuaderno en el Apéndice I) y la consideración de los 4 vv. finales del soneto X, «¿Quién de cristal el coraçón tuviera» (ver infra según nuestro criterio). 
Para completar nuestra descripción revisada del cuaderno de versos, entonces, hay que añadir que se trata de un cartapacio fragmentario con una extensión de dieciséis folios, extensión esta poco más o menos de una mano de papel, y de medidas $14 \mathrm{cms}$. de ancho x $20.1 \mathrm{cms}$. de largo. Es de una misma letra de escriba, aunque no profesional. Parece más bien obra de un aficionado a la recolección de una veintena de rimas amorosas de diversas procedencias, sacadas o recordadas algunas de ellas de fuentes orales, hojas manuscritas e impresas volanderas o librescas: todas ellas recopiladas seguramente por razones de divertimiento personal, aunque la inclusión de los romances bíblicos puede que apunte a un derrotero de cierta devoción religiosa intimista y una crítica de la política imperial de la monarquía española. Los folios revisten una numeración moderna consecutiva en el rincón derecho superior de cada folio. Al poema inicial le faltan los primeros $44 \mathrm{vv}$., los que aparecen en una versión íntegra en otra colección, los Quarentos ca[n]tos de diuersas y peregrinas historias, declarados y moralizados, por el magnifico cauallero Alonso de Fuentes (Sevilla, 1550), fenómeno que nos hace concluir previsoriamente que los textos que han pervivido en el manuscrito del Archivo Histórico de Protocolos de Barcelona son una parte significativa de un cancionero original algo más extenso acaso con titular ${ }^{14}$; al número XVI, también le faltan 53 vv., y al poema número $\mathrm{X}, 4 \mathrm{vv}$. cruciales.

La letra del ms. no dista mucho en estilo caligráfico visual de la de los números 399 (Madrid, 15 de febrero de 1565), 403 (Madrid, 26 de septiembre de 1579) y 418 (Madrid, 11 de septiembre de 1571) registrados por Millares $\mathrm{Carlo}^{15}$. Dicha letra de copista resulta a veces errática a primera vista y por ende problemática: no del todo fácilmente descifrable para luego establecer su transcripción fidedigna con precisión. Se incrementan los retos así relacionados con la transcripción por las numerosas lecciones deturpadas, truncadas y erróneas, debido a palabras tachadas y posteriormente enmendadas - aquello seguramente como consecuencia de un lapso de concentración o memoria imperfecta por parte del recopilador. Es asimismo factible que este hubiera trabajado con textos manuscritos y acaso impresos, primitivos y defectuosos. Por ejemplo, parece que hubiera trabajado con fuentes manuscritas y/o impresas diversas y distintas en la primera serie «tradicional» de los tres romances veterotestamentarios; igual conclusión se puede extraer a propósito del romance cuarto, de tema mitológico, profano, obra representativa de una segunda serie de composiciones poéticas. Y también se puede seguir un argumento parecido para la tercera, cuarta y quinta series de versos de la «novísima» moda de rima

14. Ibid., "Canto quinto de la primera parte.», ff. xxii" ss, «Perseguido anda Dauid».

15. Millares Carlo (1983), I, cap. XXVII, «La escritura en España en el siglo Xvi. Documentos reales», 250-253, y el cap. XXVIII, «La escritura en España en el siglo Xvı y primera mitad del XVII. Documentos particulares», 255-272. 
italianizante en lengua castellana. De otro modo, ¿cómo se explicarían las múltiples variantes significativas que se cuentan entre los textos manuscritos que se han guardado en el cuaderno y la lectura de los demás testimonios de difusión mayormente conocida? La cuarta serie, representativa del soneto, «Quán mal parece al mundo un movimiento», cuya acción narrada sucede en Barcelona, forzosamente ha de provenir de otra fuente, ésta puramente local, de difusión más bien manuscrita u oral, ya que su primer verso no está registrado ni catalogado en ninguna base de datos bibliográfica como, por ejemplo, la de la Biblioteca Nacional de Catalunya ${ }^{16}$.

El cuaderno es sobre papel, con una sola filigrana en los ff. 7r-8v, la que es de una mano guanteada y metálica de caballero andante, con el dedo pulgar a la derecha y una flor de cinco pétalos extendida verticalmente hacia arriba del dedo cordial. Dicha filigrana la designa Briquet mediante la siguiente descripción: «main ouverte, les cinq doigts écartés, revêt dans les types les plus anciens, l'aspect d'un gant» ${ }^{17}$ ('mano abierta, con los cinco dedos apartados, que reviste en los ejemplos más antiguos el aspecto de un guante'). Es casi idéntica a sus números 10715 (Thonon, 1495, Ginebra; Siracusa, 1497; Catane, 1499), 10717 (Venecia, 1496), 10818 (Limoges, 1599), 10827 (Périgueux, 1550; parecida pero sin flor), 10840 (Toulouse, 1569), 10890 (La Grasse, 1599), 11091 (Venecia, 1478), 11158 (Palermo, 1482), 11143 (s.l., 1525; con el corazón invertido), 11152 (s.l., 1473), 11172 (Tours, 1533), 11175 (Perpignan, 1540; con una flor de seis pétalos), 11176 (Arras, 1543), 11188 (Digne, 1519), 11205 (Perpignan, 1533), 11223 (Tours, 1548), 11247 (Nantes, 1555), 11248 (Saumur, 1558), 11250 (Nantes, 1570) y 11342 (Thury, 1527); pero a fin de cuentas es idéntica al número 11246 (Madrid, 1553; de medidas 31 x 44 mms. o sea 3.1 x 4.4 cms.). Las filigranas procedentes de manuscritos catalanes semejantes pero no iguales son las que Valls i Subirà califica como «mano/Hand/mà» en lenguas española, inglesa y catalana, así respectivamente, y conectada a un puño ornado. Son sus números correspondientes, así seguidos del lugar de procedencia y la fecha de su documención los siguientes: 1653 (Vic, 1336), 1656 (Vic, 1388) y 1658 (Olot, 1411-1414) ${ }^{18}$. Resulta por ello una filigrana bastante común y ubicua en Francia e Italia, omnipresente en el siglo XIv, a fines del siglo XV y durante todo el XVI en países europeos de la cuenca mediterránea. Sin embargo, su afiliación filigranesca con la del papel del texto madrileńo de 1553 constituye una prueba suficiente de que el material del cuaderno ronda mediados del

16. Fechas cruciales para la regencia de Carlos V son: 1500 , nacimiento en Gante; 1548 renuncia al imperio; 25/10/1555 abdicación; 10/1555-01/1556 renuncias de Bruselas; su hermano Fernando le sucede; 21/09/1558 su defunción; 1560 ascenso de Felipe II. Ver Fernández Álvarez (1999), 761-788; ídem (1976), 190-192, 195, 212-214; y Domínguez Ortiz (1974), 71-72.

17. www.bnc.cat, "Catàlegs», y en consulta (09/2012) con mi colega Albert Rossich, de la Universitat de Girona.

18. Briquet (1966), III, 544b-550a. 
siglo xvi; por otro lado, su letra caligrafiada resulta otra prueba fehaciente que coadyuva a su ubicación temporal.

La hoja de guarda del cuaderno, designada «fol. i» por Madurell i Marimón, y que mide $13.2 \mathrm{cms}$. x $19.2 \mathrm{cms}$. (a diferencia de los restantes ff. que son un poco más amplios) luce el escudo imperial de Carlos $\mathrm{V}^{19}$, que es el emblema del poder imperial del Rey y Emperador del Sacro Imperio Romano, sellado como si se hubiera sacado de papel timbrado en su hoja de guarda. Tal emblema mide $5.5 \mathrm{cms}$. de ancho x $7.4 \mathrm{cms}$. de largo, y ofrece la lectura de las palabras en latín «plus» y «ultra» en su parte inferior, como orla de sendas columnas pequeñas; dicha inscripción designa al imperio español de ultramar. Encima del escudo, por la parte derecha superior, está dibujada una torre, almenara o castillo con dos personajes dentro y banderas o estandartes a cada lado horizontal y a su vez por encima: puede muy bien ser el dibujo representativo de la corona de Castilla y León. Debajo del escudo se ve un dibujo fascinante realizado a mano, llevado a cabo con cierta precisión realista y artística. Es de una reina o acaso una figura de Medusa con coraza y corona, de pelo rizado bellamente peinado, que se lanza con una daga o un puñal en la mano derecha alzada, lista para apuñalar o degollar a un caballero de rodillas delante de ella. El caballero aparenta revestir dos caras superpuestas, una algo por encima de la otra; se le distingue una especie de cola de escorpión que sale de la barba en forma de extensión grotesca. En la parte inferior del brazo izquierdo del hombre $\mathrm{u}$ hombre-monstruo, hay una contraseña de un círculo que contiene por dentro una pequeña columna vertical por el centro, con orla u objeto anillar en medio. A mano derecha de la designada víctima varonil se ve una espada clavada en la tierra. Encima de la cola, por la parte derecha, tres palabras parcialmente legibles en letra cuidadosamente caligrafiada. Podrían leerse: "que un sou» o "quoi un soit», o algo muy por el estilo. Más bien parece un recuerdo algo lejano de una divisa — "Honi soit qui mal y pense» ('Maldad para aquel que maldad engendre') — en francés antiguo, lema este de la Nobilísima Orden de la Jarretera, cofraternidad de caballeros ingleses medievales pertenecientes a esta organización militar, que se remonta al año 1348, del reinado de Eduardo III de Inglaterra. Pervive aún esta corporación en la actualidad $^{20}$. Si en efecto es la dicha divisa - y así lo creemos-, entonces en

19. No consta tal filigrana en Valls i Subirà, II (1970), ni tampoco en Churchill (1965).

20. Las fuentes consultadas son las sigs.: Messía de la Cerda y Pita (1990); Pardo de Guevara y Valdés (1987), especialmente 48 para el escudo de armas del Emperador Carlos V; y de suma relevancia, Riquer (1942), especialmente 63, para las "Armas de Carlos I de España». Sorprendentemente, la explicación y descripción más completa y así acertada del escudo de armas del Emperador Carlos V es la basada mínimamente en Simbolos de España, (2000), 191-193 y 196, 191-193 y 196, s.v. «Escudo de España», subapartado "Casa de Austria», p. 3 de 7: «Como resultado de la política de alianzas matrimoniales de los Reyes Católicos, a la muerte de Fernando en 1516, hereda las Coronas de Castilla y de Aragón, su nieto Carlos de Habsburgo, hijo de Juana I "la Loca" y Felipe I "el Hermoso", y nieto del Emperador Maximiliano de Austria por línea paterna. Las armas de Carlos I añaden a las de Castilla, León, Aragón, Dos Sicilias y Granada, 
esta hoja de guarda constan dos emblemas harto distintos: uno habsbúrgico, de connotación española e imperial, y el segundo inglés, pero en lengua francesa, cuya representación gráfica es el dibujo / garabato extraordinario: en efecto la reina coronada o Medusa con serpientes en la cabeza como rizos, paga la maldad del caballero grotesco con otra maldad, que es la de su muerte inminente. Una

presentes en el escudo anterior, las de Austria (de gules y una faja de plata), Borgońa moderno (de azur, sembrado de flores de lis de oro y bordura camponada, cantonada de plata y gules), Brabante (de sable y un león de oro, coronado de lo mismo, lenguado y armado de gules) y Tirol (partido de plata y un águila de gules, coronada, picada y membrada de oro, cargado el pecho de un creciente trebolado de lo mismo). Carlos I incorpora también las columnas de Hércules con la leyenda "Plus Ultra", en representación del Imperio ultramarino, y rodea el escudo con el collar del Toisón de Oro, como soberano de dicha Orden. Al ser coronado Emperador en 1519, timbra el escudo con la corona imperial y acola el águila bicéfala del Sacro Imperio Romano-Germánico. A partir de 1520 añade al cuartel correspondiente a Aragón y Sicilia, otro en el que se incorporan las armas de Navarra y del Reino de Nápoles (formadas por los blasones de Jerusalén y Hungría)». Ver asimismo "Las Armas Reales de España», consultado el 23/4/2012: «Escudo cuartelado. En el primer y en el cuarto cuartel, un contracuartelado del cuartelado de gules y un castillo de oro, almenado de tres almenas, con tres homenajes, el de en medio mayor y cada homenaje también con tres almenas, mamposteado de sable y aclarado de azur (por el Reino de Castilla) y de plata y un león de púrpura, coronado de oro, lenguado y armado de lo mismo (por el Reino de León); en el tercero partido, cortado en su diestra de oro y cuatro palos de gules en el jefe (por el Reino de Aragón), en la base de gules y una cadena de oro, puesta en cruz, aspa y orla, cargada en el centro de una esmeralda de su color (por el Reino de Navarra), y en su siniestro partido, a la diestra de plata y una cruz potenzada de oro cantonada de cuatro cruces latinas del mismo metal - Jerusalén-y a la siniestra fajado, ocho, de gules y de plata — Hungría - por el Reino de Nápoles); en el cuarto partido, cortado en su diestra de oro y cuatro palos de gules en el jefe (por Aragón), en la base de gules y una cadena de oro, puesta en cruz, aspa y orla, cargada en el centro de una esmeralda de su color (por Navarra), y en su siniestra partido y flanqueado, jefe y puntas de oro y cuatro palos de gules, flancos de plata y un águila de sable, coronada de oro, picada y membrada de gules (por el Reino de Sicilia). En el segundo y tercer cuartel un cuartelado: en el primer cuartel, de gules y una faja de plata (por Austria); en el segundo cuartel, de azur, sembrado de flores de lis de oro y bordura componada, cantonada de plata y gules (Borgońa Moderna); en el tercero, bandado de oro y de azur con bordura de gules (Borgoña Antigua); en el cuarto, de sable y un león de oro, coronado de lo mismo, lenguado y armado de gules (por Brabante); sobre el todo escusón partido de oro y un león de sable, lenguado y armado de gules (por Flandes), y de plata y un águila de gules, coronada, picada y membrada de oro, cargado el pecho de un creciente trebolado del mismo metal (por Tirol). Entado en punta de plata y una granada al natural, rajada de gules y hojada de dos hojas de sinople (por Granada). El escudo rodeado con el collar del Toisón de Oro, acola el águila bicéfala del Sacro Imperio Romano-Germánico sobre la Cruz de Borgoña de gules. Acompañado de dos columnas de plata, con la base y capitel de oro, sobre ondas de azur o azul y plata, superada la corona imperial la diestra, y de una corona real la siniestra, ambas de oro, y rodeando las columnas una cinta de gules o rojo, cargada de letras de oro, en la diestra «Plus», y en la siniestra «Ultra», (del latín Plus Ultra). Timbra la corona imperial, que es un círculo de oro, engastado de piedras preciosas, cerrada con forma de mitra, compuesta de ocho florones de hojas de acanto, visible cinco, interpoladas de perlas y de cuya parte central, abierta, salen tres arcos o diademas decorados con pedrería o perlas, rematada la central en el mundo de azur o azul, con el semimeridiano y el ecuador en oro, sumado de cruz de oro. La corona forrada de gules o rojo.». Quisiera expresar mi agradecimiento más genuino a mi amiga la historiadora Rosa Rivas, de Madrid, por su ayuda en la designación y subsiguiente explicación del escudo. 
relación temática estrecha entre este dibujo fascinante y el contenido amoroso del cuaderno de poemas no se puede especificar en absoluto, pero por lo menos sabemos que no estamos tan distantes del mundo de las órdenes militares del bajo medievo, que seguían vigentes a mediados del siglo xvi. Y como el santo patrón del orden es Saint George (ingl.) / San Jorge (esp.) / Sant Jordi (cat.), es factible que hubiera una vinculación significativa entre la elección de la divisa y la cultura catalana.

Volviendo al manuscrito mismo como objeto, su estado está cada vez más deteriorado, especialmente los folios 2r-9v. Los márgenes de estos, en su parte superior y en la dobladura, se están desmenuzando, carcomidos por insectos con el paso del tiempo. Asimismo el papel se está oscureciendo y su letra se está amarilleando y desvaneciendo, tanto que ahora se observan puntitos de color marrón y anaranjado en él, seguramente por oxidación, como resultado de la base ferrosa de la tinta original. Se notan apreciables manchas de degradación por el efecto de agua o humedad excesiva, un problema propio del clima húmedo de Barcelona. Por esta causa resulta imprescindible una conservación adecuada de forma inmediata.

Incluso la reproducción xerocopiada del texto, una vez fotografiada digitalmente con una resolución óptica de $300 \mathrm{dpi}$ [=dots per inch], resulta visualmente superior a la presentación original en estado actual, por gozar de una presentación sobresaliente en tinta negra, como se puede apreciar en las reproducciones fotográficas del manuscrito incluidas en el Apéndice I de nuestro estudio. La labor meticulosa de su transcripción a cargo de los que firman el presente estudio (i.e. K.B. y G.G.S.R.) ocupó buena parte de seis meses seguidos e intensivos, además de incluir dos estancias prolongadas de K.B. en el Archivo Histórico de Protocolos de Barcelona donde cotejar la lectura del original frente a las transcripciones ya llevadas a cabo, para acabar de perfilar asimismo la lectura de la grafía en el recto y el dorso de los folios. Así se pudo descifrar el texto a pesar de la apariencia de palimpsesto del manuscrito. El análisis realizado in situ resultó sumamente beneficioso para el perfeccionamiento de la transcripción.

En cualquier caso, guiándonos por la filigrana del papel madrileño, fechada en 1553, así como por el estampado del escudo de armas del rey Carlos Quinto, Emperador del Sacro Imperio Romano y Germánico ${ }^{21}$, además de por su letra caligrafiada, y luego por su afiliación genética con otros cancioneros impresos y manuscritos de la época, caso abordado en el aparato crítico que acompaña cada poema, el cuaderno del AHPB ha de datarse forzosamente hacia mediados

21. Curiosamente, en la portada del impreso de la BUB, sign. B64/4/18, del poeta catalán de principios del siglo xvII, Vicent Garcia (1703), a pie de página se lee la inscripción, borrosa, «Domingo Solans Cler[gue]». Parece letra de la segunda mitad del s. XviII. ¿¿Será acaso el mismo individuo? Agradezco en este punto a mi colega Albert Rossich, de la Universitat de Girona, la aclaración de ciertas precisiones referentes a este mencionado ejemplar. 
del siglo XVI, coincidiendo cronológicamente con la época juvenil tardía y luego de madurez en la productividad poética de Don Diego Hurtado de Mendoza (1504-1575; Darst xi), ingenio cortesano cuyos poemas (6) representan el número más cuantioso de los de autor conocido que se encuentran en el poemario.

En cuanto a otras indicaciones escritas en el cuaderno, a mano derecha (para nuestros ojos), en la hoja de guarda (fol. 1v), está la siguiente inscripción en lengua catalana, redactada y manuscrita en letra de la época posterior a la de mediados del siglo xvi: «Libre de nafres y soluzions D. Doming» $[s i c]^{22}$ y «Capitol universal de nafres y solucions de continus [į?]». La mencionada inscripción en catalán se referirá a una especie de manual del ars medica, cuyo título correctamente deletreado en catalán moderno sería Capitol universal de nafres o Llibre de nafres $i$ solucions. Es decir se refiere a un manual de medicina que versa sobre la curación de heridas (i.e. "nafres»). Precisamente existe en la Biblioteca General de la Universidad de Barcelona el Ms. 556, una «Miscelánea médica» dedicada a "les nafres» ${ }^{23}$. Su tratado VI reza "De les Nafres» y el título de su capítulo I se lee, «De la essència y differència de les nafres» (ff. 150r-167v). Un segundo códice en catalán de la misma colección universitaria, el Ms. 426, contiene «recetas para fabricar tinta y curar nafres», sobre papel del siglo XviII ${ }^{24}$. Una conclusión razonable es que estas indicaciones se garabatearon en el folio en una época muy posterior (i.e. hasta principios del s. XVIII) a la de la composición del cuaderno de versos (ca. 1550) y que su vinculación con el tema ahí contenida es nula, aunque muy bien pueden señalar a un tal «Don Domingo» o tal vez un 'Don Domènec' de los siglos XVII y XVIII, acaso presbítero barcelonés, nuevo lector predilecto de las poesías, a la vez aficionado a la ciencia médica, y que tenía acceso a dichos textos además del cuaderno de versos en su biblioteca conventual o eclesiástica.

Además de esta última inscripción, a mano izquierda se leen en latín las siguientes palabras, «magnificat ... gloria», que son las primeras voces del cántico mariano "Magnificat Gloria Patri», entonado comúnmente a la Virgen, durante la liturgia vespertina en la Iglesia católica apostólica romana, «con el fin de agradecer el acto divino de haber escogido a María para dar a luz al Salvador, además de reconocer la salvación que se ha otorgado a Israel». Mediante la voz «Gloria» se alaba a las tres personas en un solo Dios ${ }^{25}$. Este dato refuerza nuestra hipótesis de tratarse de una colección vinculada en algún momento clave de su génesis con la vida de un claustro barcelonés.

22. Es «sobre papel, s. XviI-XviII, 204 ff. útiles». Descripción citada de Mateu Ibars (1998), 218 219 (para el Ms. 556) y la 217 (para el Ms. 426).

23. Mateu Ibars (1998). Ver asimismo Farnés i Julià (1985), III, 141-147, Mateu Ibars (1993), 197-216, e ídem (1981), II, 187-203.

24. Encyclopedia Britannica (2002) 5, 133, $3^{\mathrm{a}}$ col.-134, $1^{\mathrm{a}} \mathrm{col}$.

25. Carson y Cerrito (2003), 43b-44a. 


\section{Nuestro propósito}

El fin es aquí presentar una edición filológicamente rigurosa y crítica del manuscrito. Para lograr tal objetivo nos hemos guiado por las directrices metodológicas ofrecidas por Alberto Blecua, en su clásico Manual de crítica textual ${ }^{6}$, por Germán Orduna, en Ecdótica: Problemática de la edición de textos ${ }^{27}$, por Ignacio Arellano y Jesús Cañedo, eds., en Crítica textual y anotación filológica en obras del Siglo de $\mathrm{Oro}^{28}$ y por Miguel Ángel Pérez Priego, en La edición de textos. Con respecto al rastreo de fuentes documentadas de los veintiocho poemas, se ha fiado de la intensa labor organizacional que el equipo investigador de la Universidad Autónoma de Madrid presenta en el Catálogo de manuscritos de la Biblioteca Nacional con poesía en castellano de los siglos XVI y XVII ${ }^{29}$. También para esta labor nos hemos guiado por la utilísima base de datos, la «Bibliografía de la Poesía Áurea» o BIPA ${ }^{30}$, a cargo de José Labrador Herraiz y Ralph DiFranco, así como por las siguientes publicaciones magnas a cargo de Antonio Rodríguez-Mońino: 1) La SiLva DE Romances de Barcelona, $1561^{31}$, 2) Lorenzo de Sepúlveda, Cancionero de romances (Sevilla, 1584) $)^{32}$, y 3) Nuevo diccionario bibliográfico de pliegos sueltos (siglo XVI ${ }^{33}$. Y en último lugar nos ha servido la consulta de toda edición impresa de las obras de los autores cuyas poesías aparecen en el cuaderno de versos, además de todo cancionero y colección poética impresa originalmente en España en la época áurea y actualmente en edición moderna al alcance del investigador. Dichos cancioneros aparecen en el aparato crítico de las notas a pie de página.

\section{Descripción temática del poemario}

Un repaso por los poemas incluidos en el cuaderno «renacentista» con más precisiones que las ofrecidas según la ficha bibliográfica incluida supra, nos brinda un

26. A. Blecua (1990).

27. Orduna (2000).

28. Arellano y Cañedo (1991). De especial relevancia para el presente estudio ahí incluidos son los trabajos de Ignacio Arellano, «Edición crítica y anotación filológica en textos del Siglo de Oro. Notas muy sueltas», 563-586; Mariano de la Campa, "Los sonetos satíricos de Villamediana en la Biblioteca Nacional de Madrid. Hacia un catálogo-edición», 47-88; Víctor Infantes, «Textos y texto de un poema áureo: La vida del estudiante pobre (c. 1584)", 259-292; y Antonia María Ortiz Ballesteros, "Algunos problemas métricos en la edición de textos poéticos del Siglo de Oro», $367-$ 375.

29. Rojo Alique, et alii (1998-2007).

30. Base de datos preparada en colaboración con los Profs. Ralph DiFranco y José Labrador Herraiz (1998), en conexión con su proyecto de investigación, "Colección Cancioneros Castellanos", subvencionado por el National Endowment for the Humanities, la University of Denver y la Cleveland State University.

31. Rodríguez-Mońino (1969).

32. Sepúlveda (1967).

33. Rodríguez-Moñino (1997). 
repertorio variado en los motivos de temática amorosa, imagenería de máximo ingenio y, a fin de cuentas, una creatividad expresiva superior: El poema I, «Perseguido anda David", fragmentario, es un romance bíblico, cuya fuente escrituraria es la Biblia judía ${ }^{34}$ (1 Samuel IX:15-16; X:27; XIII:1, 13-14; XIV:48; XV:1-3, 6, 9, 10-11, 17-23, 26-27; XVI:13; XVIII: 8-9, 14-17, 20-21, 25-29; XIX:1-2, 18; XXV:1; XXVIII:3-19; XXXI:1-6). Parece ser un solo romance suelto emparentado con una serie harto más extensa de romances más breves sobre el mismo monarca israelita Saúl (ca. 1029-1005 AEC) ${ }^{35}$. Su fábula versa sobre el heroico primer rey de Israel, la intercesión de la bruja de Endor, la resucitación milagrosa del profeta Samuel, por quien había sido ungido el rey y con quien se había llevado mal por razones político-religiosas, el castigo y las subsiguientes muertes violentas y horripilantes de los hijos del rey israelita así anunciadas por el profeta, la derrota del ejército de Israel bajo el rey Saúl frente a los filisteos en la batalla del Monte Guilboa, el suicidio del monarca en campo de batalla, y la posterior sucesión del Rey David, el yerno de Saúl, a quien este odiaba y temía por celos.

El número II resulta ser un romance de origen tanájico (i.e. basado en la Toráh o sea Pentateuco) con rima consonante, sobre el patriarca José y sus hermanos (referido en Génesis XXXVII:1-11) ${ }^{36}$. Ahí se cuenta su conocidísimo sueño, su supuesta muerte a manos de sus hermanos, así como su venta y posterior entrega por parte de esos hermanos a mercaderes de una caravana en ruta hacia Egipto; 3. En el número III se lee una continuación del romance anterior, historia veterotestamentaria contada de nuevo en rima consonante, sobre la relación del Faraón con José, ya esclavo de Putifar, el cortesano y mayordomo del máximo regente egipcio (Génesis XXXVII:36; XXXIX:1) ${ }^{37}$. Puede que la elección de este romance sea por razones de la prefiguración del advenimiento del mesiánico Jesús, ya que a José se le denomina «Salvedor» [sic] de su pueblo (III.v.111), de acuerdo con la traducción de San Jerónimo ${ }^{38}$ así como con los comentarios al respecto del misterioso andaluz Alonso de Fuentes, en su Libro de los quarenta cantos (Sevilla $1550)^{39}$. Curiosamente, los anteriores tres romances, primero, segundo y tercero,

34. La Biblia Hebreo-Español (1996), I, 455-498.

35. Se incluyen otros romances de historias afines en el aparato crítico que acompaña el romance. 36. Para la historia tanájica (i.e. relativa a la contada en la Torá) del profeta José, ver Encyclopedia Judaica (1971), vol. 14, 909-918.

37. EJ, 10, 202-216.

38. San Jerónimo lo llama «Panej» o «Safenat-Paneaj», es decir «salvador del mundo». Me he basado en Cantera Burgos (1967), 102. Para bibliografía sobre el personaje de José, consultar Girón-Negrón y Minervini (2006); Díaz-Mas (1997); y Gutwirth (1996).

39. Según Alonso de Fuentes, Canto tercero de la primera parte, fol. $\mathrm{xv}^{v}$ : «y entrando en él, este Joseph sancto $\mathrm{p}[\mathrm{er}] \operatorname{seg}[\mathrm{u}] \mathrm{ido}$ de sus hermanos, quie[n] otro es sino Jesu christo n[uest] ro señor, perseg[u]ido de sus hermanos, los judíos: de los quales tomó carne: y assí el Ángel le llamó Joseph quando le puso el nombre a Jesús, que quiere dezir, Saluador.»; en la Declaració [n] del canto quarto de la primera parte, fol. ixx": «y mandó que todo lo que mandasse fuesse hecho: $\mathrm{y}$ se obedeciesse en toda su tierra, en la cual le llamaba[n] el Saluedor. Y de aquí subcedió, q[ue] venidos los años de 
figuran como los números quinto, tercero y cuarto en el texto impreso del sevillano $^{40}$. Aquí acaba la primera serie de poemas del cuaderno.

IV. Este número, "Allá en la gran Babilonia», es un romance sobre los amores fatídicos de Píramo y Tisbe, protagonistas de la fábula mitológica basada en Las Metamorfosis de los dioses, de Ovidio (Libro IV, vv. 55-166). Un motivo ampliamente conocido, que sirvió a Góngora para su célebre fábula burlesca ${ }^{41}$. Se narra en una rima que oscila entre consonancia y asonancia, y su autoría se asigna en el manuscrito, mediante la siguiente designación: "otro[,] de Oropesa» ${ }^{42}$. Por divergir temáticamente de los anteriores tres romances bíblicos, consta por sí sola como la segunda serie poética del cuaderno, aunque, tal como se ha comentado anteriormente, los primeros tres figuran asimismo en el cancionero confeccionado por Alonso de Fuentes (1550), y este cuarto aparece, con variantes muy significativas, y exclusivamente en la edición medinaense del Cancionero de romances, de Lorenzo de Sepúlveda (1576).

En este punto terminan las dos primeras «series» de cuatro romances, y enseguida empieza la tercera. V. Es el soneto «Estoi contino en lagrimas bañado», anónimo en el cuaderno, cuya autoría es de Garcilaso de la Vega (su son. XXXVIII 1995). La fábula versa sobre un amor no correspondido; VI. Le sigue otro, esta vez bien conocido, de Gutierre de Cetina, sobre el desafortunado naufragio y la subsiguiente muerte del patético Leandro: es en plena imitación del muy esmerado soneto 29 de Garcilaso, "Pasando el mar Leandro el animoso» "33; VII. Viene a continuación el poema VII, un soneto anónimo, levemente satírico, que versa sobre los celos de la infortunada Hero, que no comprende o no es capaz de comprender el retraso de llegar de su amado; VIII. Aquí se lee un soneto anóni-

la hambre: los hermanos de Joseph vinieron a comprar trigo en Egypto...»; y en la Moralidad del canto quarto, fol. $\mathrm{xxvi}^{\mathrm{r}-\mathrm{v}}$, «... Sant Pablo dize al pecador: «Levántate tú que duermes y alumbrarte ha Christo» (como si dixesse) «Haz tú de tu parte lo que es en ti»: si quieres que Christo te dé lumbre de gracia. Y pues por declarar a los soberuios / y temporales / y auarientos. Christo ser sueño todas las delectaciones / y honrras y bienes temporales desta vida: le subcedió lo que al sancto Joseph que fue de sus hermanos preso y encarcelado / y maltratado: mas la summa prouidencia y diuina sabiduría proueyó, que por aquella vía que fue humillado por allí fuesse exalçado: y que fuesse saluador uniuersal y con pregón ençalçado..." [Énfasis nuestro].

40. El romancero de los Quarenta cantos (Sevilla 1550), con su comentario doble, comienza con el romance «Muy viejo estaua ya ysac» (ff. $\left.\mathrm{v}^{\mathrm{r}}-\mathrm{vi}^{\mathrm{r}}\right)$; en segundo lugar incluye a «Labán a Iacob su yerno» (ff. ix $\mathrm{x}^{\mathrm{v}}-\mathrm{x}^{\mathrm{r}}$ ); seguido de «A Ioseph niño pequeño» (ff. $\mathrm{xiiii}^{\mathrm{r}}-\mathrm{xv}^{\mathrm{r}}$ ) en su posición de Canto tercero de la primera parte; «Durmiendo está pharaón» (fol. $\mathrm{xvii}^{\mathrm{r}-\mathrm{v}}$ ) en cuarta posición; $\mathrm{y}$ «Perseguido anda Dauid» (ff. xxiir-xxiiir) en quinta.

41. Para la transmisión de este mito en la literatura española áurea, ver Ife (1974) y Lázaro Carreter (1961). Para la versión gongorina, máximo ejemplo del barroco español, ver Góngora (2000), 525-567.

42. Alonso de Fuentes, en su Libro de los quarenta cantos, cit., fol. $57 \mathrm{v}$, se refiere al «libro nono de [la] Pharsalia», del mismo Oropesa, mencionado supra e infra.

43. Cossío (1957), 174-175; ídem (1952); reseńa de éste, a cargo de Antonio Alatorre, NRFH, XI, 1957, 77-84; Alatorre (1956); e ídem (1961). 
mo sobre Leandro, y que narra que este, picado por los celos, hace lo imposible por alcanzar a su amada, pero el acto heroico queda frustrado, incumplido; IX. El IX es un soneto anónimo, cuya fábula la narra la voz de la penada Hero, quien no se sostiene ni tolera la distancia geográfica que la separa de su amado.

En esta parte termina la tercera serie de poemas y seguidamente comienza la cuarta: X. Tal número, "Quien de cristal el corazon tuviera», trata de un soneto fragmentario y anónimo, que reviste un discurso estilísticamente elocuente. Su brillantez discursiva es la declaración o declamación de la constancia amorosa de un caballero hacia su dama ingrata. La elegancia de estilo y elocuencia de discurso desde luego eran características del ingenio poético extraordinario del poeta cortesano por excelencia cuya obra impresa no aparece hasta la editio princeps de $1610^{44}$; XI. El número XI es un soneto anónimo que versa sobre el amor imposible a una distancia infranqueable; XII. Es éste un soneto bien conocido de Diego Hurtado de Mendoza, dirigido a doña Marina de Aragón, una décima musa; XIII. El XIII es un soneto anónimo sobre el amor no correspondido, pero de autoría atribuida al mismo poeta cortesano, Don Diego Hurtado de Mendoza (de ahora en adelante DDHdM). El número XIV es otro soneto más del mismo poeta que aparece aquí sin designación de autoría (aunque atribuido a Cetina en otro lugar, ver apartado de testimonios). La voz del poeta cortesano por excelencia habla de la ausencia de la dama deseada; XV. He aquí un soneto anónimo, atribuido a DDHdM en la edición crítica contemporánea de Diez Fernández (2007), sobre la ausencia y distancia física imposible que separa al caballero de su dama. Su discurso, en un tono retórico elevado, evidencia fluidez descriptiva y léxica, además de dominio de la armonía del verso; su tema es afín a la del poema XI: el amor imposible a una distancia infranqueable; XVI. El número XVI consta como un soneto anónimo sobre el amor no correspondido; XVII. Este otro soneto, atribuido a DDHdM en el cuaderno de versos, pero atribuido con mayor certeza a Cetina, es un ejemplo ilustrativo de la estética de Ut pictura poesis, aunque sin la plasticidad imperante del verso común al primero o a Garcilaso; XVIII. El número XVIII es un soneto anónimo y si seguimos la frase nominal «del mismo», su autoría se adscribiría a Cetina; su fraseología y expresividad son loables por su perfección enunciativa y la descripción ofrecida en sus vv. 1-8 se asemeja a la de la desafortunada Dorotea, protagonista cervantina, en el Quijote, capítulo 28; XIX. Este número se presenta como otro soneto más de DDHdM, aunque es de Montemayor. Es muestra de la perfección formal que se esperaría del ingenio del poeta cortesano luso, y versa su fábula sobre el poder del amor que entra por la vista; XX. Henos aquí ante un soneto anónimo sobre las quejas de amor de un caballero desamado; se atribuye a Montemayor en su Cancionero (1554); XXI. Para poner fin a la serie, el XXI es un soneto atribuido a DDHdM por Díez Fernández

44. Para una introducción erudita a la vida y obra del poeta granadino, ver Darst (1987). 
(2007), sobre el alma masculina que ha experimentado el rechazo por parte de la dama perfecta, que es más dura de corazón que un diamante y más hermosa que lo imaginable $e^{45}$. La cuarta serie de poemas acaba en este lugar, con la quinta empezando y a la vez terminando con el poema siguiente.

XXII. Este número es un soneto anónimo y desconocido de tono levemente satírico sobre una señora barcelonesa que se ha metido monja en el convento de Santa Catalina, de la Ciudad Condal ${ }^{46}$. En tono de lamento teńido de sátira se viene contando que "ha muerto el amor» porque las bellas damas barcelonesas han dejado la vida mundana por la conventual; por ello el mundo anda al revés. En este punto acaba esta quinta serie tan breve y comienza la sexta y serie final de poemas.

XXIII. El siguiente es un soneto anónimo sobre Hero. Parece mal colocado, ya que por su contenido debería aparecer en la tercera serie de poemas, todos ellos sobre el mito de Hero y Leandro. XXIV. Nuestro número XXIV es también un soneto anónimo sobre Hero, en el que se aborda el tópico del amor no correspondido, aquello por la muerte trágica de Leandro. Como el anterior, pertenece a la tercera serie de poemas. Se destaca entre sus vv. la unión tan equilibrada del trasfondo de reflexión sobre la naturaleza, y la forma sobria del poema además de la delicadeza del ejemplo y la argumentación natural, no forzada. XXV. Este soneto anónimo recrea un retrato de la perfección pictórica de la naturaleza además del narcisismo, se transmite en un discurso rico en plasticidad a la vez que lirismo como visualidad. XXVI. El número XXVI es una muy conocida epístola anónima en tercetos, cuyos protagonistas son los pastores cortesanos Meliso y Libea; hasta cierto punto reviste una imitación digna de la Égloga III, vv. 233248, de Garcilaso de la Vega, por la descripción del nombre de la amada difunta grabado en la corteza de los árboles ${ }^{47}$ : «cuérdate que en árbres dexauas, / escrito

45. Esteban de Nágera (1993), 247-264, poemas núms. cxviii-cxxvi, incluye asimismo una pequeña antología de "Obras de don Diego de Mendoza».

46. Para cierta actividad literaria a mediados del siglo Xvir así relacionada con este mismo convento barcelonés, ver Brown (1987), 176-177; y Garçón (1600), con «aprovación por Fray Thomas Roca Presentado», 3, «Presentado y lector de prima de Theología en el convento de Santa Caterina mártyr de Barcelona 20 junio 1600». La segunda "aprovación» en este impreso es a cuidado de «Fray Juan Vicente del convento de Santa Caterina Mártyr». Se podría añadir a estos pocos casos el contado por Camprubí y Anglés (1743), referente a la relación del auto de fe en Barcelona, el 8 de Julio de 1668, bajo título de «Auto del Sant Tribunal de tres reos apóstatas [sic] de nostra santa fe al judaïsme y reconsiliació de aquells,» p.246.

47. Según Morros, ed. Garcilaso (1995), 236 n.248, «El epitafio grabado en la corteza de un álamo presenta cierta analogía con la inscripción que figura en el túmulo de Mopso (Virgilio, Bucólicas, V, 43-44), que recuerda la costumbre entre los pastores de grabar en los árboles, bien sus versos de amor (Virgilio, Bucólicas, V, 11-12; y Calpurnio, I, 33-88), bien el nombre de su amada (Virgilio, Bucólicas, X, 54-55; y Ovidio, Heroidas, V, 21-24). Los vv. de Garcilaso son los sigs.: "Una d'aquellas diosas que'n belleza / al parecer a todas ecedía, / mostrando en el semblante la tristeza / que del funesto y triste caso había, / apartada algún tanto, en la corteza / de un álamo unas letras escribía / como epitafio de la ninfa bella, / que hablaban ansí por parte della: / «Elisa 
el nonbre mjo que creçiendo / mi memoria subias y ensalçauas» (vv. 28-30). Este poema epistolar ha sido atribuido a DDHdM, responsable de numerosas otras poesías epistográficas ${ }^{48}$ y a la vez a Pedro Guzmán cuya autoría parece ser la aceptada en la actualidad; XXVII y XXVIII. Aquí finalizan el cuaderno dos quintillas anónimas e interrelacionadas sobre un juego de corte.

\section{Conclusiones}

El contenido del cuaderno de poemas del Archivo Histórico de Protocolos de Barcelona ofrece una breve colección de poemas amorosos, bíblicos y mitológicos para el uso y la lectura personal, cuyo tono discursivo, muy parecido al de los cancioneros de la época, oscila entre lo serio y lo levemente satírico. En su totalidad, el repertorio poético consta de romances, sonetos, tercetos y quintillas - tres de ellos, los bíblicos, más bien tradicionales, a la vez existentes en el Libro de los quarenta cantos (1550), con romances afines en el Cancionero de romances (1576), impresos. A partir de la serie de romances bíblicos, luego la colección evoluciona en una obra renacentista. Es de notar que la temática de sus fábulas gira en torno al amor, con todos sus vaivenes de afectos, confusiones, desengańos y percances emocionales involucrados. Píramo y Tisbe, además de Hero y Leandro, son sus protagonistas más célebres y omnipresentes. Tampoco falta el amor imposible o no correspondido entre un caballero contemporáneo y su dama.

En resumen, los autores representados en el cuaderno de 28 poemas son Garcilaso de la Vega, 1 seguro (núm. V); Diego Hurtado de Mendoza, 5 seguros (núms. XII, XIII, XIV, XV y XXI); Gutierre de Cetina 2 seguros (núm. VI, XVII) + 1 posible atribución (núm. XVIII); Montemayor, 2 seguros (núms. XIX y XX). Los demás son anónimos seguros y de éstos algunos tal vez atribuibles (núms. XVIII, XXV, XXVI, XXVII y XXVIII).

Cabe especificar el que en los sonetos anónimos no hay fuente conocida, por lo que no podemos examinar las variantes. Los rasgos de estilo en esta serie de sonetos apuntan a una arquitectura defectuosa del soneto, que persigue en algunos casos la armonía del tono de languidez petrarquista, pero que parece cojear por la escasez en la variedad de adjetivos e incluso la preferencia por motivos de

soy, un cuyo nombre suena / y se lamenta el monte cavernoso, / testigo del dolor y grave pena / en que por mí se aflige Nemoroso / y llama: ‘Elisa`, ¿Elisa`; a boca llena / responde el Tajo, y lleva presuroso / al mar de Lusitania el nombre mío, / donde será escuchado, yo lo fío."”.

48. Compararse, por ejemplo, con las sigs. epístolas poéticas de su ingenio donde entra el nombre de Marfisa, la musa traviesa suya, según la ed. de Díez Fernández (2007): Epístola VI, 84-91; Epíst. VIII, 98-101; Canción II, 176-185; Epíst. X, 176-185; Soneto XXXVII, 365; Égloga II, 367-371; Epíst. XI, 396-400, que empieza «Salud, señora mía, os enviara»; la Égl. II, 644-653; y el «poema de atribución compartida», la Carta III, 577-581. Aquello dicho, aunque Díez Fernández nos advierte que "[e]l uso del nombre "Marfisa" es un criterio claramente insuficiente para la atribución a Mendoza» (676). 
cariz popular, como la «Dama que entró al convento». Se diría que su autor está adaptándose no sólo a una versificación novedosa, como la del soneto, sino a una composición breve, con un esquema estrófico de rima variable pero de extensión limitada en el número de versos. El vocabulario arcaizante, incluso rústico, aparece en consonancia con la expresión de una «sabiduría natural», que transparenta el sentido común del romancero y que contrasta con las sentencias filosóficas con las que dialoga el espíritu cortesano y su tendencia a los cultismos ${ }^{49}$.

La impresión de estar inacabados todos los sonetos, no bien pulidos, se compensa con la viveza de las escenas en la que los personajes se lamentan a través del diálogo con una naturaleza animada.

Uno de los rasgos de mayor originalidad del breve cuaderno es el haber explotado la perspectiva femenina de Hero en equilibrio con la pasión amorosa de Leandro. Y a pesar de que los sonetos sobre Hero no presenten la perfección formal de los otros sonetos de autores conocidos, ponen de manifiesto a un poeta no sólo de gran sensibilidad espiritual, amorosa y religiosa, sino que también busca cierta originalidad en el proceso creativo, ya que se mueve entre la imitación de modelos conocidos y la adaptación a un modelo de verso, el endecasílabo: novedoso dentro del sistema rítmico del castellano. Estos rasgos, la impericia formal y la originalidad del punto de vista femenino en la pareja amorosa, son indicadores de que, tal vez, el cuaderno sea expresión de un proceso de aprendizaje, de ensayo en la modalidad del verso endecasílabo que estaba ocurriendo en la península, por influencia de los cancioneros italianos y la moda petrarquista. El cuaderno de versos se encuadra en el ambiente editorial urbano de la Barcelona que fue sede para la publicación de las obras de Boscán y Garcilaso (1543) y de numerosos cancioneros.

También es de gran originalidad uno de los sonetos, el XXII, dedicado a la mencionada dama anónima que ingresó en un convento barcelonés. La estructura de inversión social que presenta la conclusión del soneto, es por la idea de que «anda al revés el mundo». De hecho, en conexión con esta broma algo irreverente, el soneto anterior, el XXI, que comienza «mis ojos de llorar están cansados», atribuido en otras fuentes a Hurtado de Mendoza, presenta en el cuaderno un cambio sustancial en el último terceto, citado más arriba, por el que se da pie a una lectura burlesca sobre la reina de la belleza a la que se dirige el poema. ¿Tal vez la apropiación apunte a una broma erasmista o a un espíritu alumbrado? En cualquier caso, la línea de comentario social del anónimo profundiza en la nota de las clases sociales como en el tratado por Cetina, el XVIII, sobre una rústica labradora, aunque la lógica petrarquista de éste no se encuentre en el de tema religioso.

La nota neoplatónica del tratamiento de la naturaleza también está presente

49. Lapesa (1985), «Poesía de cancionero y poesía italianizante», 213-238, y «El cultismo semántico en la poesía de Garcilaso», 239-254. 
en la composición anónima XXV. En éste, sin embargo, no aparece el plano femenino, sino que se centra exclusivamente en la naturaleza. De nuevo, podríamos barajar la idea de un autor que experimenta con el molde del nuevo género poético, que intenta conciliar la intensidad del sentimiento garcilasiano con la vena contemplativa y reflexiva de la poesía italianizante de Diego Hurtado de Mendoza. A pesar de su hechura neoplatónica, hay un desajuste estético, como de no estar completamente pulido debido al uso de un léxico de connotaciones rústicas que no se ajusta al tema filosófico, por lo que contrasta con el buen diseño de los modelos.

En fin, lo que el benemérito bibliotecario e historiador barcelonés Madurell i Marimón denominaba un mero «Pliego de versos» renace de las cenizas del olvido como un joyel precioso, guardado justamente por casualidad entre los «miles de metros lineales de estanterías» del Archivo Histórico de Protocolos de Barcelona: poemario representativo de la mejor creatividad lírica tanto al itálico modo cuanto al estilo y metro castizo de la España de Carlos V. Obrita de numen secular, laico; su excepcionalidad notoria radica en brindarnos rimas nuevas y novedosas, nunca anteriormente vistas ni en códice manuscrito ni en página impresa, además de múltiples versiones tempranas de obras posteriormente conocidas en letra de estampa. Sirve como un ejemplo más del sumo interés y de la fascinación de la ya establecida y nueva onda de poesía española que se leía en la Ciudad Condal a mediados del s. xvi.

\section{Criterio de la edición y últimos pormenores}

La presente transcripción y subsiguiente edición de los poemas contenidos en el Ms. «Pliego de versos» 29 - Legajo I del Archivo de Protocolos de Barcelona, se atiene a la normativa paleográfica más rigurosa: no se actualiza ni la puntuación, ni la capitalización, ni la acentuación de los poemas en su presentación primaria. El razonamiento que ha guiado la confección de la edición paleográfica radica en ser el nuestro un intento de respetar la forma visual del original. En efecto, el texto editado aparece transcrito tal como se lee en el cuaderno manuscrito, salvo muy pocas excepciones. No obstante, se resuelve toda abreviatura en letra cursiva, como, por ejemplo, vro > vuestro (V.14), vra > vuestra (XIX.9), y se reconstruyen exclusivamente aquellas lecturas deturpadas en el original a causa de la condición defectuosa del papel, de la tinta o de la letra, y cuya reconstrucción resulta obvia: como, por ejemplo, en el caso de Samue $>$ Samue[1] (I.63), perd...a > perd[id]a (X.13), «in tin ción» > intinción (= intención) (II.70) y «des tino» > destino (VI.14). En el caso de existir dos formas deletreadas de la misma voz, en variación libre, como en el poema III, v.63 "panetero", y III, v.71 "panatero", se guardan ambas lecturas en su forma original respectiva; y al leerse en el códice un error de gramática imperdonable, como en el caso de III, v.86, «sus significado", se ha dejado tal como aparece en el original, pero queda resuelto en la edición modernizada. 
La transcripción exacta de dos letras que aparecen a veces indistinguibles visualmente y por ello difíciles de resolver con perfección en el manuscrito son la «b» y la «v» minúsculas, pero como su valor fonemático es idéntico, su transcripción no resulta problemática por razones enunciativas, aunque puede que hayamos incurrido en su presentación visual errónea. Se puede apreciar el dilema nuestro en la edición facsímil incluido en nuestro Apéndice I.

Anomalías expresivas en el texto son mínimas, pero apuntan a un escriba / copista / recopilador catalanohablante. Ejemplos se perfilan en el poema IV, v.100, «el piramo» (i.e. forma designatoria en el catalán central del uso del artículo personal masculino y femenino, delante de nombres de pila y apellidos con el fin de designar el nombre de pila de uno o una ${ }^{50}$ ); I.95 «major» en lugar de «mayor», que refleja una pronunciación catalana del fonema bastante fricativo, palatal y sonoro [3], frente a la articulación española más suave, menos fricativa de la yod $[\dot{j}]$, fonema palatal sonoro ${ }^{51}$; II.41, «Jusep» (articulado de tal manera en el catalán actual para articular una «o» en posición átona pero escrito actualmente "Josep»); tal vez II.60 «cuerp» (< «corp», aunque se emplea «cos» en catalán actual; es admisible dicha acepción fonemática, a medio camino entre «cuerpo» \{español\} y «cos» \{catalán\}); III.72 «muriria» en lugar de «moriria», por la pronunciación catalana en que una "O» en posición átona se articula como la vocal alta, «u»; y el poema XXII.11 «les cofias» en lugar de "las cofias», donde «les» es la forma correcta del artículo definido femenino y plural así deletreado en lengua catalana.

Adicionales anomalías de deletreo son el nombre propio «Jaco» o «Jacó» (poema II.3), tal vez un calco del judeoespañol hablado en España anterior a la expulsión de la población judía a mediados del año 1492, cuando efectivamente dicho nombre de pila, Jaco o Jacó < Jacob, era y aún es común entre los de dicha comunidad ${ }^{52}$. Ahora bien, en el Cancionero de Jorge de Montemayor, poeta portugués que escribía en español, existen ambas formas "Jacob" y "Jacó» en el poemario sacro del mismo poeta luso, Fundamenta Eius in Montibus Sanctis, poema "Hizo Dios una ciudad» (vv. 11-13): «Quales fueron las comarcas / sobre que Dios la fundó / Abraham, Isaac y Jacó». Y además tanto en el título en latín, Diligit Dominus Portas Sion Super Omnia Tabernacula Jacob, así como en su v. $3^{53}$. En el poema I de nuestro cancionero, v. 59, la voz «sumuel» por «Samuel» se aleja de su pronunciación esperada en lengua romance, pero puede que provenga del original hebreo, que se extiende luego al judeoespañol «Shmuel» / שמוּאל, transcrita fonemáticamente /'Smu-'el/. Si esto es cierto, entonces se complica aún más la labor de confección del pequeño cancionero,

50. Ruaix i Vinyet (1983), II, 47.

51. Badia i Cardús (2002), 222; y Schwegler, Kempff y Ameal-Guerra (2010), 271.

52. Ver, por ejemplo, Cantera Burgos (1971).

53. Montemayor 1554, 1562 y 1558 y Cantos (1996), 153-154. 
tanto con respecto a las fuentes de las que aprovechaba el recopilador cuanto al conocimiento del hebreo por parte del copista.

Se nota el hecho de que el mayor número de poemas pertenece a Diego Hurtado de Mendoza ( 5 seguros +3 posibles, X, XI y XVI), poeta cuya tradición textual no ha sido críticamente fijada según la afirmación de Díaz Larios y Gete Carpio $(1990,47)$. Seguimos aquí y nos guiamos por las ediciones de Díez Fernández (2007) y la citada de Larios y Gete Carpio, y reconocemos la labor rigurosa en la recogida y anotación de las fuentes de procedencia de ambas para la presentación de sus textos.

Las variantes de forma son constantes a lo largo del cuaderno, lo que revela una conciencia crítica de la lengua. Se destacan los siguientes: el uso de la ç en lugar de c o z, como en «absençia» (IX.1); de la ç en lugar de la combinación — $\mathrm{xc}$ - , como en «eçede» (XXII.11); del grupo consonántico -nb- = -mb-, como en «enbidia» (II.9); de la -rr- en posición inicial, como en «rrigión» = región (poema V.14); de las oscilaciones vocálicas de - e, i-, e - y-, como en «aflejía» (XXIV.10), "vían» = veían (V.10), "criado» = creado (XXV.3), "perfiçion» (XVIII.4, y XXV.2), y "creería» en lugar de creyera (X.4); de la confusión entre el uso de $\mathrm{b} y \mathrm{u}$, como en "cabsa» (I.110 y VIII.8); del uso confundido de la -oy -u-, como en «sospirando" (IX.8) y «durmía» (VII.2); del empleo de "segir» (XV.5), similar a «juzge» en XX.9, de Montemayor; de variaciones raras como en «lishonjas» (XXII.10); de oscilaciones entre la e y la o, como en "escura»= oscura (V.14); y de la representación en el deletreo invertido, de «alderredor»= alrededor (II.20) y «vernan» = vendrán (III.95). Por fin se nota la elisión de la e en «cria» = creía (XIII.2).

Variantes de sustancia son mínimas, lo que refleja el cuidado del copista. Las seńalamos en aparato crítico. En los sonetos adscritos a DDHdM, las variantes son indicativas de que las versiones de sonetos conocidos son próximas a las del primer editor Díaz Hidalgo en 1610. Así el soneto XV11, he aquí «viviré y moriré» en lugar de "duraré y permaneceré», que presentan las ediciones modernas.

Las omisiones de conjunciones, así como el error de orden de los tercetos que cierra un famoso soneto de Diego Hurtado de Mendoza, el XXI, indican que, tal vez, en el caso de las composiciones más famosas, el copista mientras en el acto de estar transcribiendo estaba fiándose de su memoria no del todo exacta. Así:

Más brava sois conmigo que no leona

más dura sois, señora, que no diamante por

Más dura sois señora que diamante

más brava sois señora que leona

Como mencionamos, los errores son mínimos y existe cercanía a la tradición textual del primer editor. Una de las variantes próximas a la edición de 1610, es la inversión de la secuencia "callando despierta», en el conocido soneto 
de Hurtado de Mendoza, que comienza con el verso «Vuelve el cielo y el tiempo huye y calla», núm. XIV en el cuaderno. El participio pasa a posponerse, transcribiéndose como «despierta callando». Esta variante sería insustancial en cuanto al sentido, pero teniendo en cuenta otros errores hacia el final del mismo poema, se podría considerar una interpretación alternativa en la apropiación del motivo petrarquista. Así en los vv. 10 y 13: «día bienvenido» por «día que estaré», y "por lo que a sido» en lugar de "por lo que fue». También el verso que cierra el último terceto presenta un cambio sustancial, "que menor es tu mal estando absente», en lugar de "menos son tus males en ausencia», convirtiendo las causas plurales en malestar al singular. Con lo cual la causa única no es nombrada, y podría ser motivo para la especulación interpretativa.

Para concluir, fuera de unos pocos ejemplos de intervención reconstructiva muy justificada, cualquier otro reajuste de lecturas equivocadas se realiza exclusivamente en el aparato crítico, que se divide entre cuatro apartados: 1 . uno de notas que corresponden a variantes de versos de acuerdo a otros testimonios, sus variantes de acuerdo a otras lecturas, y cuyo fin es explicar su forma moderna; 2. Un segundo, de notas a final de texto, cuyo propósito es citar fuentes de información, explicar voces oscuras o referencias y alusiones difíciles de comprender para el lector contemporáneo; 3. Un tercero, de fuentes bibliográficas; 4. Un último apartado, con una versión actualizada, modernizada del texto en cuanto a la división por estrofas, al deletreo actualizado correcto y a la acentuación de acuerdo a las normas vigentes en el momento actual. Al final de la edición, en forma de Apéndice I, se reproduce íntegro mediante reproducción fotográfica digital con una resolución de 300 dpi el manuscrito poético. En el Apéndice II se reproduce sin reconstrucción y corrección alguna una serie de romances veterotestamentarios afines a los que aparecen en el cuaderno de versos y que proceden del pliego suelto, Aquí comiençan seys romances (s.d., s.l.), Sign. R. 261850, BNC, ff. 2r-2v, y de Lorenzo de Sepúlveda, Cancionero de romances (1576 Medina del Campo). Nuestra intención ha sido, a su vez, ofrecer un texto legible al estudioso de la poesía áurea.

\section{La edición}

[fol. 1r] [I.] [Anónimo y fragmentario. Romance en rima consonante]

[Perseguido anda Dauid ${ }^{54}$

de Saul y mal tratado

fuese con los Philisteos

y al rey de Geth se a llegado

54. Fábula bíblica contada en 1 Samuel IX:15-16; X:27; XIII:1,13-14; XIV:48; XV:1-3, 6, 9, 1011, 17-23, 26-27; XVI:13; XVIII:8-9, 14-17, 20-21, 25-29; XIX:1-2, 18; XXV:3-19; XXXI:1-6. 


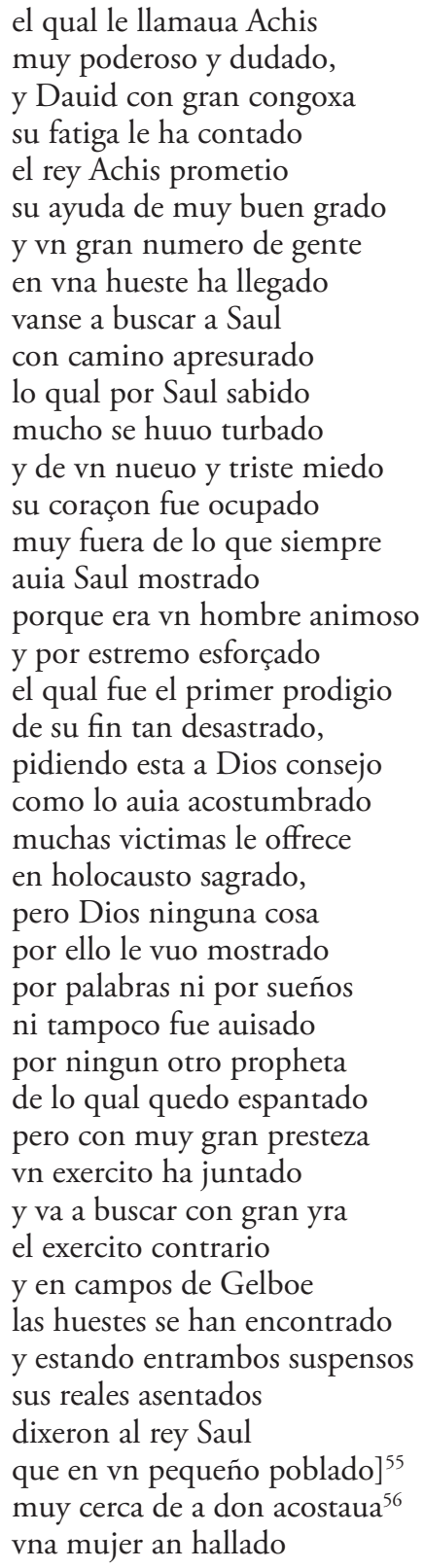

55. Aquí empieza la lectura del ms. Lo que le antecede proviene del texto tal como se lee en el Libro de los quarenta cantos.

56. Verso defectuoso, eneasílabo. Su lectura correcta es «muy cerca de adó acostaua». Ver infra la transcripción modernizada. 


$$
\begin{aligned}
& \text { la qual era phitonisa }{ }^{57} \\
& Y \text { estauan çertificados } \\
& \text { que con sus majicas artes } \\
& \text { avria prenosticado } \\
& \text { muy grandes cosas ocultas } \\
& \text { antes que oviesen llegado } \\
& \text { luego se partio Savl } \\
& \text { para uella disfraçado } \\
& \text { con solos dos honbres suyos } \\
& \text { por ir mas disimulado } \\
& \text { llegados a pitonisa } \\
& \text { con gran amor le a rrogado } \\
& \text { le diga el fin de la guerra } \\
& \text { Y que le seria pagado } \\
& \mathrm{Y} \text { asi mjsmo le rrogo } \\
& \text { vn caso bien escusado } \\
& \text { que al profeta Samue[1] } \\
& \text { fuese alli rresuçitado } \\
& \text { que abia poco que era muerto } \\
& \text { para ser aconsejado } \\
& \text { la maga le rrespondia } \\
& \text { con aspeto muy ayrado } \\
& \text { dime uienes por uentura } \\
& \text { a tentarme di soldado } \\
& \text { no sabes quel rrei Savl } \\
& \text { a poco que uuo mandado } \\
& \text { que mago }{ }^{58} \text { y hechizeras } \\
& \text { fuesen luego desterrados } \\
& \text { [1v] Saul co mill juramentos } \\
& \text { aviendola asegurado } \\
& \text { la maga ya satisfecha } \\
& \text { sus çercos a començado } \\
& \text { Y el profeta samuel } \\
& \text { ouo ally rresuçitado } \\
& \text { vnos tienen que fue el profeta } \\
& \text { otros espiritu dañado } \\
& \text { Y sabido que saul } \\
& \text { era el que le avia hablado } \\
& \text { la maga con gran miedo } \\
& \text { dixo que la abia engańado } \\
& \text { dixo el rrei que no temiese } \\
& \text { Y le contase de grado } \\
& \text { todo lo que avia visto } \\
& \text { Y la maga le a contado }
\end{aligned}
$$

57. Es una referencia a la bruja de En-Dor / עיןדוֹר (1 Samuel 28:7-19). Ver EJ, 6, 738-739.

58. La lectura tendría que ser forzosamente paralela en plural, es decir «magos». 
Señor yo ueo vnos dioses en hermosura dotados que de la tierra an subido y Saul le a preguntado que forma tenia el major de aquellos si a mirado ella dixo es ya muy uiejo cubierto de vn rrico paño conoçiendo a samuel saul en tierra se a echado Y caydo en nella de ynojos a samuel a adorado

[2r] Enpero sumuel ${ }^{59}$ le dixo porque me as enqujetado para que rresuçitaste lo que estaua escusado el rrei Saul rrespondio con gran pesar muy turbado muy grande neçeçidad dio cabsa de te auer errado los filisteos pelean contra mi y dios me a dexado no quiere rresponderme Y por esto te e llamado para que tu me aconsejes como se a rremediado rrespondiole Samuel para que me as fatigado dios se apartara de ti Y sera con tu contrario $Y$ te quitara tu rreino dauid sera coronado porque no le obedeçiste ni heziste su mandado el qual contra abumalec ${ }^{60}$ no quesiste executallo

59. En hebreo, שמוזאל / 'Smu'el. Ver supra.

60. Error por parte del poeta en cuanto a la historia bíblica, ya que la obligación, divinamente impuesta, era que el rey Saúl y su ejército exterminaran a todo ser humano y animal relacionado con Amalec (I Samuel 15:3). Dicho nombre extraño, en la Toráh se emplea para referirse al enemigo que practica abominaciones en guerra contra los indefensos. Un ensayo inteligente sobre «La memoria de Amalek", se encuentra en The Torah. A Modern Commentary (2006), 454-455. Por ejemplo se explica que «Amalek fue el nombre de una tribu nomádica o grupo de tribus que se encontraban en la península de Sinaí y la parte meridional del desierto del Negev». Los amalecitas (por ejemplo, en I Samuel XXX:1) se consideraban los «archienemigos» del Pueblo de Israel, y Dios/Adonay había ordenado a Saúl a exterminarlos sin excepción, en una especie de guerra santa, cosa que no lo llevó a cabo totalmente el rey de Israel. De ahí su condenación por la divinidad suprema. 
Y mañana tu i tus hijos

sereis comigo lleuados

45 [de donde estaua; 46 [muger han; 47 [qual ... Phitonisa; 48 [estauan certificados; 49 [magicas; 50 [auia pronosticado; 51 [occultas; 52 [vuiessen; 54 [Ø uella; 55 [hombres; 56 [yr ... dissimulado; 57 [llego a la Phitonisa; 58

[ha rogado; 60 [y; 61 [assi mesmo le rogo; 63 [el propheta; 64 [fuesse ... resusçitado; 65 [auia; 67 [Maga ... respondio; 68 [aspecto; 69 [vienes ... ventura; 70 [tentarme; 71 [el rey Saul; 72 [ha ... huuo; 73 [magos y hechizeros; 74 [fuessen todos; 75 [con mil; 76 [auiendola assegurado; 77 [Maga; 78 [cercos ha; 79 [y al propheta Samuel; 80 [vuo alli resuscitado; 81 [el propio; 82 [que spiritu; 83 [y; 84 [auia; 85 [Maga ... grande; 86 [auia; 87 [rey ... temiesse; 88 [y ... contasse; 89 [auia; 90 [y la Maga; 91 [señor yo veo; 92 [de; 93 [han; 94 [ha; 95 [mayor; 96 [auia; 97 [dixo, ... viejo; 98 [rico manto; 99 [conociendo a Samuel; 100 [ha; 101 [hincado en ella; 102 [Samuel ha; 103 [pero Samuel; 104 [has inquietado; 105 [resuscitalle; 106 [lo qual; 107 [rey ... respondio; 109 [mi ... necessidad; 110 [causa de auer; 111 [Philisteos; 112 [Dios ... ha; 113 [y no ... responderme; 114 [y ... ha; 116 [sea remediado; 117 [respondiole; 118 [has; 119 [Dios; 120 [y; 121 [y ... reino; 122 [Dauid; 123 [obedeciste; 125 [Abimalech; 126 [executallo,; 127 [y ... y; 128 [sereys

Testimonios: Alonso de Fuentes, Quarenta cantos de diversas y peregrinas historias, declarados y moralizados, por el magnifico cavallero Alonso de Fuentes, Sevilla, ff. xxiir-xxiiir. Rodríguez-Moñino, La Silva de romances DE BARCELONA, I 56I, Salamanca, Universidad de Salamanca, 591a, alista un título parecido, "Quando murió el rey Saúl y Ionatás su hijo amado», incluido en [Lorenzo de] Sepúlveda, Cancionero de romances, Medina del Campo 1576, 269, pero no es éste sino otro poema de fábula parecida (Ver romance infra). En la 109, R-M pone: «Reimpresión de Medina del Campo, 1576. Casi un cuarto de siglo después, el medinés Francisco del Canto estampaba por cuenta del editor Benito Boyer una nueva impresión de los Romances siguiendo casi con seguridad la primera o alguna reedición hoy desconocida. Cotejándola con la de 1551, que es el texto más próximo al primitivo que ha llegado hasta nosotros, advertimos que hasta el poemita que comienza Los galos entran en Roma inclusive corren parejas, pero a raíz de eso hay varias alteraciones. Suprime la Elegía valenciana, la piececita Aunque me falte osadía y el largo texto relativo a Berbería, conserva los cinco restantes y añade siete nuevos. El primero de ellos: $380 \mathrm{Al}$ pie del mar del Esponto aparece en un pliego tardío de la biblioteca de Cracovia 9 Romance de Leandro, compuesto por Juan de Boraualias Mayayo. Con dos Sonetos y otras siete canciones a modo de dialogo pastoril muy sentidas (Granada, Hugo de Mena, 1570) y no lo vemos en cancioneros anteriores a esa fecha. Las cinco que siguen y que comienzan respectivamente: 381 Por los bosques de Cartago, 382 Quando murió el rey Saúl, 383 Israel mira tus montes, 384 En la rueda de Fortuna, 385 Los cielos andan rebueltos se hallan en un pliego suelto Aqui comiençan seys romances. El primero del rey don Pedro. El segundo de Paris. El tercero del rey don Juan. El quarto de Eneas y Dido. El quinto del rey Saúl. El sexto de Polinestor, conservado 
en dos tiradas (110) diferentes: una (dos ejemplares) en la colección de Espona y en la Biblioteca Nacional de Madrid, la otra en Praga.». Gracias a la erudición de A. R.-M., Nuevo diccionario bibliográfico de pliegos sueltos poéticos, ed. corregida y actualizada por Arthur L.-F. Askins y Víctor Infantes, Madrid, Castalia, y Mérida, Editora Regional de Extremadura, 1997, 569, hemos podido localizar dos copias del dicho pliego suelto en BNE, sign. R/9475, y BNC, sign Esp. 95. El romance, Israel, mira tus montes, se incluye en Sepúlveda, Cancionero de romances (Medina del Campo, 1576), ff. 269v-270v, ejemplar consultado de la Stadbibliothek Ulm, y que se reproduce en el Apéndice II.

TRANSCRIPCIÓN MODERNIZADA

[Perseguido anda David de Saúl y mal tratado, fuése con los Filisteos y al rey de Geth se ha llegado, el cual le llamaba Achis, muy poderoso y dudado, y con David con gran congoja su fatiga le ha contado. El rey Achis prometió su ayuda de muy buen grado y un gran número de gente en una hueste ha llegado. Vanse a buscar a Saúl con camino apresurado, lo cual por Saúl sabido mucho se hubo turbado; y de un nuevo y triste miedo su corazón fue ocupado, muy fuera de lo que siempre había Saúl mostrado, porque era un hombre animoso y por extremo esforzado, el cual fue el primer prodigio de su fin tan desastrado. Pidiendo está a Dios consejo como lo había acostumbrado, muchas víctimas le ofrece en holocausto sagrado, pero Dios ninguna cosa por ello le hubo mostrado por palabras ni por sueños ni tampoco fue avisado por ningún otro profeta, de lo cual quedó espantado; pero con muy gran presteza 
un ejército ha juntado

y va a buscar con gran ira

el ejército contrario,

y en campos de Gelboé

las huestes se han encontrado

y estando entrambos suspensos

sus reales asentados,

dijeron al rey Saúl

que en un pequeńo poblado]

muy cerca de adó acostaba

una mujer han hallado

la cual era pitonisa;

y estaban certificados

que con sus mágicas artes

habría pronosticado

muy grandes cosas ocultas.

Antes que hubiesen llegado

luego se partió Saúl

para verla disfrazado

con solos dos hombres suyos;

por ir más disimulado

llegados a pitonisa

con gran amor le ha rogado,

le diga el fin de la guerra,

y que le sería pagado.

Y asimismo le rogó

un caso bien escusado,

que al profeta Samuel

fuese allí resucitado,

que había poco que era muerto.

Para ser aconsejado,

la maga le respondía

con aspecto muy airado:

«Dime, ¿vienes por ventura

a tentarme de soldado?

¿No sabes que el rey Saúl

ha poco que hubo mandado

que mago [s] y hechiceras

fuesen luego desterrados?».

Saúl, con mil juramentos

habiéndola asegurado,

la maga, ya satisfecha,

sus cercos ha comenzado.

Y el profeta Samuel

hubo allí resucitado.

Unos tienen que fue el profeta,

otros espíritu dańado.

Y sabido que Saúl

era el que le había hablado, 
la maga con gran miedo

dijo que le había engañado.

Dijo el rey que no temiese

y le contase de grado

todo lo que había visto.

Y la maga le ha contado:

«Señor, yo veo unos dioses

en hermosura dotados

que de la tierra han subido.».

Y Saúl le ha preguntado:

«QQué forma tenía el mayor

de aquéllos, si ha mirado?».

Ella dijo, «Es ya muy viejo,

cubierto de un rico paño.».

Conociendo a Samuel,

Saúl en tierra se ha echado

y caído en ella de hinojos.

A Samuel ha adorado;

empero Samuel le dixo:

«¿Por qué me has inquietado?

¿Para qué resucitaste

lo que estaba escusado?».

El rey Saúl respondió

con gran pesar, muy turbado:

«iMuy grande necesidad

dio causa de te haber errado;

los filisteos pelean

contra mí, y Dios me ha dejado,

no quiere responderme;

$y$ por esto te he llamado

para que tú me aconsejes

cómo se ha remediado!».

Respondióle Samuel:

«¿Para qué me has fatigado?

Dios se apartará de ti,

y será con tu contrario,

y te quitará tu reino;

David será coronado

porque no Le obedeciste

ni hiciste Su mandado,

el cual contra Abumaléc

no quisiste evitarlo,

y mañana tú y tus hijos

seréis conmigo llevados ${ }^{61} . »$.

61. Es decir, «tendréis el mismo destino como es el mío», i.e. «todos los vuestros moriréis». 
[2v][II.] otro [Anón. Romance, en rima consonante]

Josep niño y pequeño
los otros sus diez ermanos
por ser de jaco su padre
sobre todos muy amado
porque en su edad postrimera
ouo este hijo engendrado
en la hermosa rrachel
por quien siruio tantos anos
muy grande enbidia le tienen
odio grande le an tomado
estando vn dia comiendo
Josef dixo a sus hermanos
escuchadme hermanos mjos
vn sueño que oue sońado
en que via todos nosotros
hazer haçes en el canpo
y el manojo que yo hize
en alto se a leuantado
y estauan vuestros manojos
alderredor vmillados(
al qual los hermanos suyos
rrespondieron enojados
soñauas lo que querrias
mochacho desuergoncado
Si piensas ser por uentura
rrey de todos y adorado
Y aquesto cabso que fuese
El odio multiplicado
luego desde a pocos dias
en que aquesto ouo pasado
otro sueño les conto
diziendo oyd que e soñado
quel sol y tanbien la luna
ante mi se an vmillado
Y con otras onze estrellas
que me estauan adorando
dixole Jacob su padre
pon rrostro disimulado

62. Fábula contada en Génesis XXIX:20, 30; XXX:22-24, 25; XXXI:41; XXXVII:1-11, 36; XXXIX:1, 2-6, 7-20.

63. Puede ser que se capte aquí la pronunciación del original hebreo, ya que en ese idioma se escribe רחל, y su transliteración fonemática es /ra-'hel/ gutural o /ra-'Xel/ uvular, a la castellana. 


que quiere dezir Jusep
este sueńo que as soñado
auemos te de adorar
yo i tu madre y tus hermanos
despues de pasado aquesto
fuese Josef parra el canpo
do sus hermanos estauan
apaçentando el ganado
hallolos en do tayn
a do llego muy cansado
los quales desque lo vieron
antes que fuese llegado
ayuntaronse ocho dellos
diziendo muy enojados
Ya biene el sońador
que nuestro rrey se a soñado
bien sara que lo matemos
Y sera bien adorado
Y alli en aquella çisterna
podra ser Su cuerp echado
Y esta sera la soltura
de los sueńos que a sońado
esto oido por rruben
le airo mucho turbado
no ensuziess las manos vuestras
en sangre de vuestro hermano
sino echaldo en la çisterna
pues que ya quereis matallo
esto dezia rruben
con yntinçion de saluallo
Y de boluello a su padre
que mucho del era amado
tomaron luego a Josef
El sayo le an desnudado
Y echaronlo en la çisterna
haziendo del grand escarnjo
boluiendose a sus estançias
vn mercader an encontrado
que venia de galatay
con camellos cargados

64. = Dothán. o Dothaim, «ciudad localizada al norte del territorio de Manasseh», EJ, vol. 6, s.v. Dothan, 179-180.

65. Galata o Galatae. «Vecindad en el distrito de Beyoglu, en la parte occidental, mirando hacia Europa, de la ciudad de Istanbul». Ver Kazhdan (1991), 815. 


\author{
dixeron vnos a otros \\ vendamos a nuestro hermano \\ que pues se sońaua rrey \\ bien sera que se esclauo \\ que muy menos ganaremos \\ en acabar de matallo \\ aqueste nueuo consejo \\ fue por todos aprouado \\ Sacanlo de la çisterna \\ los mercaderes an llamado \\ diziendoles si querian \\ comprarles aquel esclauo \\ los mercaderes contentos \\ de uer tan lindo mochacho \\ les dieron treynta dineros ${ }^{66}$ \\ porque en tanto fue ygualado \\ tomando su vistidura \\ toda la an ensangrentado \\ lleuanla a su padre viejo \\ finjendo que yuan llorando \\ diziendo que bestia fiera \\ les despedaço a su ermano ${ }^{67}$.
}

1 [A Ioseph niño pequeño; 2 [hermanos; 3 [Jaco \{/o Jacó; 5 [prostrimera; 6 [vuo; 7 [ Rachel; 8 [años; 9 [gran embidia; 10 [han; 12 [Ioseph; 13 [escuchad ... mios; 14 [vue; 16 [hazes ... campo; 18 [ha; 20 [alrededor humillados; 22 [respondeieron; 24 [muchacho desvergonçado; 25 [si ... ventura; 26 [rey; 27 [causo ... fuesse; 28 [el; 29 [dende; 30 [vuo passado; 32 [diziendo, oy; 33 [tambien; 34 [han humillado; 35 [y; 37 [Iacob; 38 [rostro dissimulado; 39 [vido; 40 [estauan muy indignados; 41 [Ioseph; 42 [has contado; 44 [yo y; 45 [passado; 46 [fuesse Ioseph para el campo; 48 [apacentando; 49 [Dothaim; 50 [donde llego ... cansado,; 52 [fuesse; 53 [ayuntaron se; 54 [enojados,; 55 [ya viene el ensoñador; 56 [rey se ha; 58 [y; 59 [y ... cisterna; 60 [cuerpo; 61 [y; 62 [ha contado,; 63 [oydo por Ruben; 64 [les dixo ... turbado,; 65 [ensuzieys; 66 [con; 67 [cisterna; 68 [quereis matarlo; 69 [Ruben; 70 [intento de saluarlo; 71 [y de boluerlo; 72 [amado, 73 [Ioseph; 74 [la saya le; 75 [y ... cisterna; 76 [gran escarnio; 77 [estancias; 78 [una requa han encontrado,; 79 [Galaath; 81 [inguentos y resina,; 82 [Egipto encaminados,; 84 [hermano,; 85 [rey; 86 [sea; 88 [matarlo; 90 [aprouado,; 91 [sacanlo ... cisterna; 92 [han llamado; 93 [diziendoles,; 94 [esclauo,; 96 [ver ... muchacho; 97 [veynte; 98 [ygualado,; 99 [vestidura; 100 [han; 101 [viejo padre; 102 [fingiendo ... llorando,; 104 [hermano

Testimonios para el romance y poemas de temática afín: Quarenta cantos, Alonso de Fuentes, Sevilla, 1550, «la primera parte, consagrada a diversas his-

66. Precio en dineros por el que se vendió a Jesús. Referirse a la variante «veynte» del texto impreso. Parece ser una variante intencionalmente cristológica.

67. Gén. XXXVII:12-35. 
torias de la Sagrada Escritura.». Allí en el mismo apartado se incluyen los sigs., no. 387, «Muy viejo estaua ysac»; 388, «Laban a Iacob su yerno»; 389, «A Ioseph niño pequeño»; 390, «Durmiendo esta pharaon»; 391, "Perseguido anda Dauid»; 392, «Ioab y el lindo Absalon»; 393, «El rey Ioran de israel»; 394, «En la ciudad de Bethulia»; 395, «El poderoso rey Dario»; y 396, «Sañoso está el rey Assuero». Textos reproducidos en nuestro Apéndice II. Cit. por A.R-M, La SILVA DE ROMANCES de Barcelona 1561, 111-112.

\section{TRANSCRIPCIÓN MODERNIZADA}

A Josef, niño y pequeño, los otros sus diez hermanos, por ser de Jacob su padre sobre todos muy amado. Porque en su edad postrimera hubo este hijo engendrado en la hermosa Rachel por quien sirvió tantos años. Muy grande envidia le tienen, odio grande le han tomado. Estando un día comiendo, Josef dijo a sus hermanos: «Escuchadme, hermanos míos, un sueño que hube soñado en que veía todos nosotros hacer haces en el campo, y el manojo que yo hice en alto se ha levantado, y estaban vuestros manojos alrededor humillados.».

Al cual los hermanos suyos respondieron enojados: «¡Soñabas lo que querías, muchacho desvergonzado; si piensas ser por ventura rey de todos y adorado!». $\mathrm{Y}$ aquesto causó que fuese el odio multiplicado. Luego desde a pocos días en que aquesto hubo pasado otro sueño les contó, diciendo, "Oíd, que he soñado que el sol y también la luna ante mí se han humillado, y con otras once estrellas que me están adorando.». Díjole Jacob, su padre, con rostro disimulado, 
porque a sus hermanos vido que estaban muy indignados:

"¿Qué quiere decir, Josef, este sueño que has sońado? ¿Habemos te de adorar yo y tu madre y tus hermanos?». Después de pasado aquesto fuése Josef para el campo dó sus hermanos estaban apacentando el ganado. Hallólos en Dothán a dó llegó muy cansado, los cuales desque lo vieron antes que fuese llegado ayuntáronse ocho de ellos, diciendo muy enojados: «Ya viene el sońador, que nuestro rey se ha soñado. ¡Bien será que lo matemos y será bien adorado, y allí en aquella cisterna podrá ser su cuerpo echado! ¡Y esta será la soltura de los sueños que ha soñado!». Esto, oído por Rubén, le airó mucho turbado: "iNo ensuciéis las manos vuestras en sangre de vuestro hermano, sino echadlo en la cisterna, pues que ya queréis matarlo!». Esto decía Rubén con intención de salvarlo y devolverlo a su padre que mucho de él era amado. Tomaron luego a Josef, el sayo le han desnudado, y echáronolo en la cisterna, haciendo de él gran escarnio. Volviéndose a sus estancias, un mercader han encontrado que venía de Galatae con sus camellos cargados, con ungüentos y resinas hacia Egipto encaminados. Dijeron unos a otros: "iVendamos a nuestro hermano que, pues se sońaba rey, bien será que sea esclavo, que muy menos ganaremos 
en acabar de matarlo!». Aqueste nuevo consejo fue por todos aprobado.

Sácanlo de la cisterna, los mercaderes han llamado, diciéndoles si querían comprarles aquel esclavo. Los mercaderes, contentos, de ver tan lindo muchacho, les dieron treinta dineros porque en tanto fue igualado.

Tomando su vestidura toda la han ensangrentado; llévanla a su padre viejo fingiendo que iban llorando, diciendo que bestia fiera les despedazó a su hermano.

[III.] otro [Anón. Romance, en rima consonante]

$[4 \mathrm{v}]$

durmiendo estaua faraon
en su palaçio acostado
con gran contento durmia
con rreposo sosegagaua
y unos temerosos sueńos
graue fatiga le an dado
porque soño que se via
çerca de vn hermoso prado
en la rribera de un rrio
de gran frescura cercado
vio salir del siete uacas
con vn paso apresurado
tan gruesas tan hermosas
que quedo muy admjrado
luego otras siete uacas
tras estas se avian mostrado
paçiendo orillas del rrio
en vn lugar abastado
muy flacas con tal postura
el cuerpo muy descarnado
aquestas uacas hanbrientas
tras de las gordas an dado
Y comieronselas todas
con lo qual fue rrecordado
y pensando en este sueńo

68. Fábula relatada en Gén. XLI:1-46. 


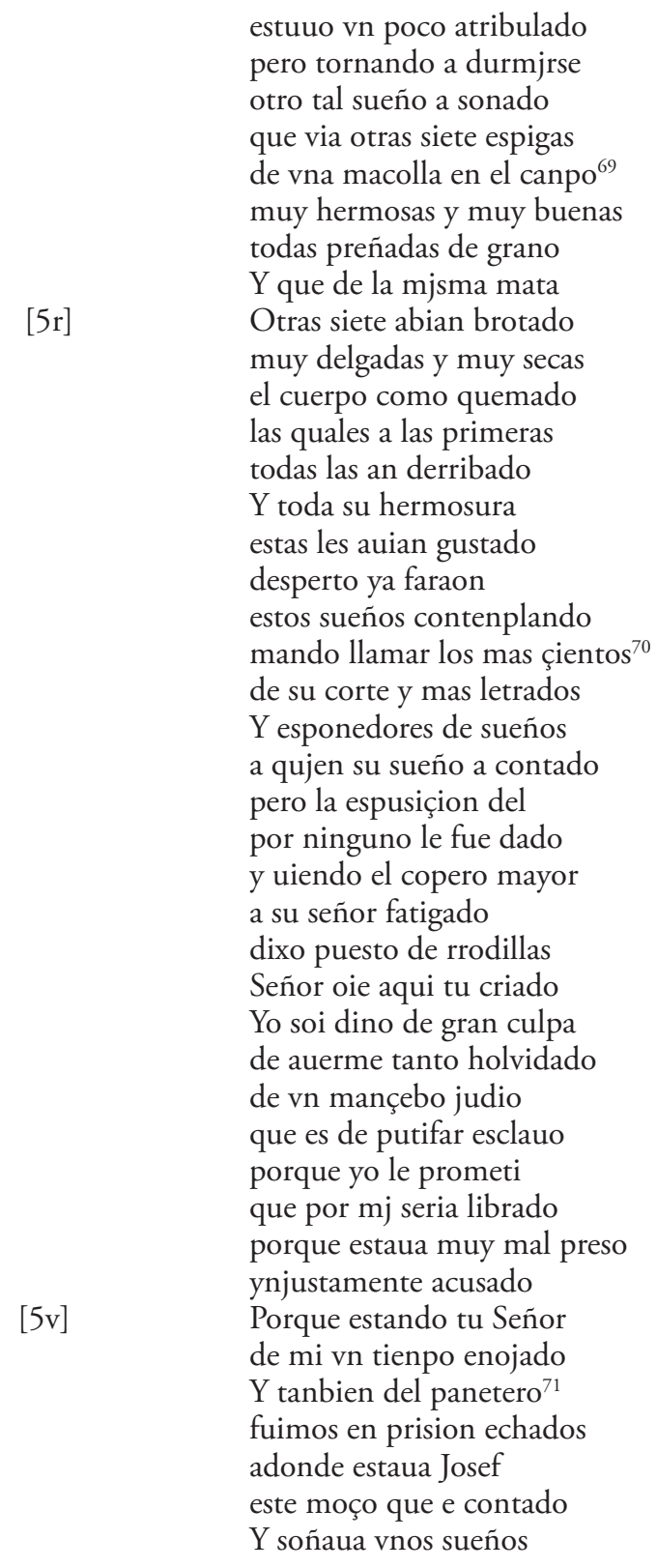

estuuo vn poco atribulado pero tornando a durmjrse otro tal sueńo a sonado que via otras siete espigas de vna macolla en el canpo ${ }^{69}$

69. macolla: D.A. «Conjunto de espigas, vástagos o flores, nacidos de un mismo pie.».

70. çientos = cientes. Ver Real Academia Espańola, base de datos CORDE, consultado el 11/01/2011, «cientes» cit. 1645.

71. Fábula relatada en Gén. XL:1-23; XLI:9-44. 
quel me ouo declarado

dixo que yo bolueria

a seruir en tu palaçio

$\mathrm{Y}$ al panatero le dixo

que muriria ahorcado

$\mathrm{Y}$ aquesto fue todo asi

como fue pronostinado

Y sabe Señor si es biuo

por que estaua mal tratado

porque es vn sabio mançebo

$\mathrm{Y}$ en esto muy avisado

con gran priesa faraon

por Josef abia enbiado

el qual uenido ante el

le dixo uen aca ermano

yo e sońado grandes suenos

que graue pena me an dado

porque mjs sabios no saben

darles sus sinjficado

Yo se que eres muy gran sabio

si en aquesto as açertado

[6r] Contole anbos los sueños

que la noche avia soñado

al qual rrespondio Josef

Señor bien considerado

las uacas y las espigas

todas una cosa an mostrado

$\mathrm{Y}$ es que vernan siete ańos

por todos estremos abastados

en esta tierra de ejito

$\mathrm{Y}$ otros siete muy menguados

de modo que todo el rreyno

se uera muy apretado

oyendo aquesto los sabios

quedaron muy espantados

por el rremedio de aquesto

por faraon prestado

les dio Josef vn consejo

por donde fue selibrado

oyendolo faraon

lo puso todo en su mano

haziendole despues del

Señor adelantado

Y mando quel Saluedor ${ }^{72}$

fuese por todos llamado ${ }^{73}$

72. Según la tradición expuesta por San Jerónimo. Ver la n. 42, supra.

73. De acuerdo a Gén. XLI:43-45. 
1 [Dvrmiendo esta Pharaon; 2 [palacio; 3 [dormia; 4 [con reposo sossegado; 5 [vnos; 6 [han; 7 [veya; 8 [cerca; 9 [ribera de vn rio; 11 [vacas; 12 [passo; 13 [gruessas y; 15 [y luego ... vacas; 16 [auian; 17 [paciendo orilla del rio; 21 [y aquestas vacas hambrientas; 22 [han dado; 23 [y; 24 [recordado; 26 [turbado; 28 [ha soñado; 29 [veya vnas; 30 [vn campo; 31 [y muy llenas; 33 [y; 34 [otras ... auian; 35 [casi secas; 38 [han; 39 [y; 40 [estas sellas han quitado; 41 [Despierto ya Pharaon; 42 [y ... contemplando,; 43 [scientes; 45 [y exponedores; 46 [ha; 47 [exposicion; 49 [viendo; 50 [fatigado,; 51 [rodillas; 52 [señor oye a tu criado; 53 [yo soy digno; 54 [oluidado; 55 [mancebo Iudio; 56 [ques de Putifar; 60 [injustamente; 61 [porque ... señor; 62 [de mi vn tiempo; 63 [y tambien; 64 [fuymos; 65 [Ioseph; 66 [he; 67 [y sońamos; 68 [que el nos vuo declarado,; 70 [a seruirte a tu palacio; 71 [panetero; 72 [moriria; 73 [y ... assi; 74 [pronosticado,; 75 [y ... señor; 77 [mancebo; 78 [y ... auisado.; 79 [Con gran piessa Pharaon; 80 [ha por Ioseph embiado,; 81 [uenido; 82 [le dixo, ven aca herinocam $\{s i c\} ; 83$ [he ... sueños; 84 [han; 86 [su significado; 87 [yo ... gran hombre; 88 [y en ... has; 89 [contole entrambos; 90 [auia; 91 [respondio Ioseph; 92 [señor; 93 [vacas; 94 [vna ... han; 95 [y; 96 [todo estremo; 97 [Egypto; 98 [y; 99 [reyno; 100 [vera; 102 [espantados,; [pero el remedio; 104 [Pharaon preguntado; 105 [le dio Ioseph; 106 [fuesse librado; 107 [Faraon; 109 [haziendolo; 110 [su mayor; 111 [y ... saluador; 112 [fuesse ... llamado.

Testimonio: Alonso de Fuentes, Quarenta cantos, no. 390.

\title{
TRANSCRIPCIÓN MODERNIZADA
}

\author{
Durmiendo estaba Faraón \\ en su palacio acostado, \\ con gran contento dormía, \\ con reposo sosegaba. \\ Y unos temerosos sueños \\ grave fatiga le han dado \\ porque soñó que se veía \\ cerca de un hermoso prado \\ en la ribera de un río \\ de gran frescura cercado. \\ Vio salir de él siete vacas \\ con un paso apresurado, \\ tan gruesas, tan hermosas, \\ que quedó muy admirado. \\ Luego otras siete vacas \\ tras éstas se han mostrado \\ paciendo orillas del río \\ en un lugar abastado. \\ Muy flacas con tal postura, \\ el cuerpo muy descarnado, \\ aquestas vacas hambrientas \\ tras de las gordas han dado. \\ Y comiéronselas todas, \\ con lo cual fue recordado
}


y pensando en este sueño estuvo un poco atribulado

pero tornando a dormirse otro tal sueño ha sońado, que veía siete espigas de una macolla en el campo, muy hermosas y muy buenas, todas preñadas de grano. Y que de la misma mata otras siete habían brotado, muy delgadas y muy secas, el cuerpo como quemado, las cuales a las primeras todas las han derribado. Y toda su hermosura éstas les habían gustado. Despertó ya Faraón, estos sueńos contemplando; mandó llamar los más cientes de su corte y más letrados, y exponedores de sueńos a quien su sueño ha contado. Pero la exposición de él por ninguno le fue dado; y viendo el copero mayor a su señor fatigado, dijo, puesto de rodillas: «Señor, oye a tu criado. Yo soy digno de gran culpa de haberme tanto olvidado de un mancebo judío que es de Putifar esclavo. Porque yo le prometí que por mí sería librado, porque estaba muy mal preso, injustamente acusado.

Porque estando tú, Señor, de mí un tiempo enojado, y también del panetero fuimos en prisión echados, adonde estaba Josef, este mozo que he contado. Y soñaba unos sueños que él me hubo declarado. Dijo que yo volvería a servir en tu palacio, y al panetero le dijo que moriría ahorcado. 
Y aquesto fue todo así como fue pronosticado. Y sabe, Señor, si es vivo porque estaba mal tratado, porque es un sabio mancebo.». Y en esto muy avisado, con gran priesa Faraón por Josef había enviado, el cual venido ante él le dijo, «iVen acá, hermano! Yo he soñado grandes sueños, que grave pena me han dado, porque mis sabios no saben darles su significado. Yo sé que eres muy gran sabio si en aquesto has acertado.». Contóle ambos los sueños que la noche había soñado, al cual respondió Josef: «Señor, bien considerado, las vacas y las espigas todas una cosa han mostrado, y es que vendrán siete años por todos extremos abastados en esta tierra de Egipto y otros siete muy menguados, de modo que todo el reino se verá muy apretado.».

Oyendo aquesto los sabios, quedaron muy espantados, por el remedio de aquesto por Faraón prestado.

Les dio Josef un consejo por donde fue celebrado; oyéndolo Faraón lo puso todo en su mano, haciéndole después de él Seńor adelantado. Y mandó que «el Salvador» fuese por todos llamado.

[IV.] otro[,] de Oropesa. [Romance, en rima consonante, a menudo imperfecta]

Alla en la gran babilonja Por semiramis ${ }^{74}$ cercada

74. Reina asiria legendaria ( $824 \mathrm{BC}-811 \mathrm{BC})$. 
avia vn lindo mançebo

Y vna donzella agraçiada

al mançebo llaman piramo

la dama tisbe llamada ${ }^{75}$ aquestos dos biuen juntos

cada qual en su posada vna pared sola en medio entre vna y otra posada entrambos hiere cupido cada qual dellos penaua uense los dos y sospiran sin poderse hablar palabra los dos buscan sus maneras por a do se den la habla hallado an vn agujero que la pared traspasaua por alli se uen los dos el buen piramo y su amada sus penas y sus dolores cada qual manjfestaua conçiertan de uerse juntos vna noche sosegada junto a vna fresca fuente questa del pueblo apartada Y metida entre arboleda [7r] Anbos consienten en ello cada qual da su palabra que en llegando a la noche yria a la fuente aplazada avn la noche no es uenida ni la jente sosegada quando la hermosa tisbe se sale disimulada de la casa de su padre sin de nadie ser mirada puesta rrica uasqujña de oro y seda labrada cuerpo y mangas de brocado $\mathrm{Y}$ una gorgera quajada de aljofar y pedreria la gorgera ua esmaltada no lleua toca njnguna ua en cabello y descofrada con vn manto de cendal

75. La fábula de Píramo y Tisbe la cuenta Ovidio Naso, en Las metamorfosis (IV, vv. 55-166). 
la tisbe ua cobijada

lleua muy gran deseo

de se uer alla llegada

con piramo sus amores

que ella tanto deseava

llegado que ouo a la fuente

se hallo desconsolada

$[7 \mathrm{v}]$

Por uerse la triste sola

sin aquel que tanto amava

allegose so vn moral

Y alli sestuvo asentada

mirando a vna parte y otra

por uer si su amor llegaua

vio uenjr vna leona

a la parte do ella estaua

toda la boca sangrienta

y de sed muy fatigada

la tisbe des que la vido

toda se sintio turbada

dexa el manto y los chapines

por huir apresurada

la leona topo el manto

y alli lo despedaçaua

$y$ allega y beue en la fuente

$y$ a la ora se tornaua

piramo luego al istante

a buscar su linda amada

y llego junto al moral

porque penso que alli estaua

$\mathrm{Y}$ uiera el manto y chapines

mas no hallo lo que buscaua

vido el manto ensangrentado

sin color se desmayaua

pensando que aquella fiera

[8r] de aquel monte la matara

diziendo palabras tristes

que a las piedras ablandara

para que genero la vida

pues my tisbe muerta estaua

la espada sacara luego

$\mathrm{Y}$ con ella se matara

la tisbe como vido

la leona no tornaua

Yuase para la fuente

donde piramo hallara

tenblandole todo el cuerpo

que el alma se le arrancaua

como lo vido la tisbe

sobre el cuerpo se desmaya 


$$
\begin{aligned}
& \text { mesa sus rrubios cabellos } \\
& \text { Y su blanca cara rrasgaua } \\
& \text { estando en esta sazon } \\
& \text { el piramo se traspasa } \\
& \text { la donzella como vido } \\
& \text { que ya el muerto quedaua } \\
& \text { tomo la espada del fuste } \\
& \text { que el cuerpo le traspasaua } \\
& \text { sin hablar njnguna gran cosa } \\
& \text { sobre la espada sechaua } \\
& \text { Y vbieron fin los amantes } \\
& \text { porque tam bien se amavan }
\end{aligned}
$$

Testimonios: Ninguno idéntico o semi-idéntico, aunque reviste ciertos paralelos con el "Alla en la gran babilonja» ("Allá en la gran Babilonia»), Lorenzo de Sepúlveda, Cancionero de romances, Medina del Campo, 1576, ff. 214r-218v. Aparece asimismo el romance «Tisbe y Píramo que fueron», tanto en la Silva de varios romances, Barcelona, Jayme Cortey, 1561, ed. Antonio Rodríguez-Moñino, Valencia, Castalia, 1953, no. 45, como en el Cancionero llamado FLOR DE ENAMORADOS (Barcelona 1562), ed. Antonio Rodríguez-Moñino y Daniel Devoto, Valencia, Castalia, 1954, ff. 46r-47r.

$$
\begin{aligned}
& \text { En la grande Babylonia } \\
& \text { que Semiramis fundara } \\
& \text { Pyramo gentil mancebo } \\
& \text { y una donzella moraua } \\
& \text { auia Tisbe por nombre } \\
& \text { en hermosura extremada } \\
& \text { ambos en edad yguales } \\
& \text { en gentileza y en gracia } \\
& \text { ningun semejante estos } \\
& \text { en su tiempo se hallaua } \\
& \text { ambos en grande amistad } \\
& \text { desde niños se criauan } \\
& \text { siendo sus padres vezinos } \\
& \text { contino juntos andauan } \\
& \text { crecio su amor con los años } \\
& \text { perfectamente se amauan } \\
& \text { sus padres lo han conocido } \\
& \text { de estoruarles ordenaran } \\
& \text { aquella conuersacion } \\
& \text { que en ellos tan viua estaua } \\
& \text { no lo pudieron hazer } \\
& \text { que su amor los remediara } \\
& \text { un esquicio muy occulto } \\
& \text { entre ambas casas hallaran }
\end{aligned}
$$


de ninguno los sentia

por alli ambos hablauan

los sus secretos amores

por alli comunicauan

los coraçones de entrambos

viendose mucho descansan

muchas vezes verse juntos

los amantes desseauan

besando, y abraçando

mas la pared lo estoruaua

$\&$ incitados con su amor

con la pared razonauan

Porque nos eres molesta

di cruel porque estoruauas

que no se junten aquestos

que tanto lo desseauan:

En estas y en otras cosas

mucho tiempo alli gastauan

hasta que ya fatigados

con la vida que passauan

y no pudiendo sufrir

lo que los atormentaua

conciertan este concierto

que otro remedio no hallan

que otro dia bien de noche

quando todos resposaran

sin que nadie los sintiesse

se saliessen de sus casas

y fuessen a un arboleda

que por lugar señalauan

para gozar sus amores

libremente, $y$ sin que aya

quien les cause impedimento

como hasta alli lo hallauan,

Venida que fue la noche

ya que todos descansauan

salio de su casa Tisbe

como la que desseaua

verse ya con su querido

como firme enamorada

al lugar constituydo

muy alegre caminaua

que la fuerça del amor

ha la hecho muy osada

cerca era de la ciudad

esta arboleda nombrada

sentose bajo un moral

mientras Piramo llegaua 
ella con grande congoxa como su amigo tardaua vio venir un[a] leona con la boca ensangrentada viene a beuer a una fuente que esta cerca do ella estaua con miedo que della tiene en una cueua se entraua dexo el manto en el camino como la que yua turbada quando beuio la leona para el bosque se tornaua vio estar el manto en el suelo con las uñas lo rasgaua hizo lo muchos pedaços todo lo ensangrentara Piramo salio mas tarde vino a donde Tisbe estaua las pisadas de la leona vido con la luna clara en el poluo ouo gran miedo mas luego se esforçara anduuo mas adelante $\&$ con el manto encontrara despedaçado y sangriento y desque tal lo mirara conocio que era Tisbe $\&$ que ella lo cobijaua, creyo su amada ser muerta tristemente lamentaua con sospiros dolorosos que el coraçon le arrancauan dezia, triste de mi deste mal fuy yo la causa deuiera ser yo el primero en venir yo a esperarla y pues fuy tan desdichado el viuir me desagrada ya desseo que viniessen leones desta montańa y este perezoso cuerpo con las sus uńas deshagan que yo merecia la muerte $\&$ no aquella desdichada pues que la mande venir donde la muerte hallara, Donde estas señora Tisbe donde estas que no me hablas? que hare agora sin ti 
biuiendo vida penada mas no es justo que yo biua sin de mi hazer vengança Esto dicho tomo el manto $\&$ al moral se allegaua llorando se los sus ojos lo besaua y abraçaua ansi hablaua con el como si fuera su amada despues de auer lamentado $\&$ afligido la su alma dixo. Recibe señora vengança que de mi daua Puso la espada en los pechos $\&$ sobre ella se arrojaua $\&$ con el peso del cuerpo saliole por las espaldas con el ansia de la muerte como el cuerpo meneaua saliale mucha sangre que todo el suelo bańaua salio la hermosa Tisbe de adonde escondida estaua creyo que seria venido Pyramo a buscar la andaua \& como no parecia a el moral se tornaua vio estar el cuerpo tendido la color amortiguada hazia tras se retiro como muger espantada parose tal como muerta el coraçon le temblaua dudosa estaua entre si $\&$ no se certificaua si era aquel el moral que quando huyo dexara despues mirando mejor conocio lo que dubdaua conocio el cuerpo estar muerto vio en el metida el espada conocio que era su amado el que muerto alli fincaua començo a dar grandes gritos lastima era mirarla el su delicado rostro con las manos arañaua y con grande crueldad los sus cabellos messaua 
$\&$ con entrańable amor

el cuerpo muerto abraçaua

$\&$ muy amorosamente

en el rostro lo besaua

con boz ronca de llorar

deste suerte razonaua:

Dime Pyramo señor

posseedor de mi alma

di quien en tan breue tiempo

tal como estas te parara

respondeme señor mio

hablad a quien os hablaua

yo soy la que siempre amastes

yo soy la que vos amaua

abrid essos vuestros ojos

mirad a quien os llamaua

catad que soy vuestra Tisbe

señor mio alça la cara

abrio Pyramo los ojos

ya quel alma se le arranca

quando oyo el nombre de Tisbe

$\&$ mostro que se alegraua

quiso hablar \& no pudo

porque su fin lo estoruaua

\& luego en el mismo punto

en sus braços espiraua

quando ella conocio el manto

$\&$ lo vido qual estaua

alço los ojos al cielo

de nueuo tanto lloraua

que los ayres con las quexas

de sus bozes resonauan

$\mathrm{y}$ viendo como salia

por las espaldas la espada

dixo: $\mathrm{O}$ sin ventura yo

o que desdicha tamaña

que ofensa hize a mis dioses

porque ansi me castigauan

aquel que fue causa desto

a el os ruego mal aya

no es justo este yo mas biua

pues que tu ya no lo estauas

a mis parientes y tuyos

aquesto yo les rogaua

nos entierren a ambos juntos

nuestro amar lo demandaua

en la vida yguales fuymos

y en la muerte desastrada

$\&$ tambien ruego a los dioses 
me concedan suplicaua

que en memoria deste hecho

a este arbol sea mudad[a]

la fructa que sea muy negra

la qual agora es muy blanca

pues tanto mal encubria

merecen le den tal paga

Desque esto ouo hablado

a su amigo se acercaua

saco la espada del cuerpo

$\&$ con ella se matara

junto a Pyramo cayo

muertos alli los hallaran

lleuaron los sus parientes

a Babilonia su patria

sus padres los lloran mucho

el pueblo los consolaua

a Piramo \& Tisbe amantes

en un sepulchro [e]nterrauan.

TRANSCRIPCIÓN MODERNIZADA

Allá en la gran Babilonia, por Semíramis cercada, había un lindo mancebo y una doncella agraciada. Al mancebo llaman Píramo, la dama Tisbe llamada; aquestos dos viven juntos cada cual en su posada. Una pared sola en medio entre una y otra posada, entrambos hiere Cupido, cada cual de ellos penaba. Vense los dos y suspiran sin poderse hablar palabra; los dos buscan sus maneras por a dó se den la habla. Hallado han un agujero que la pared traspasaba, por allí se ven los dos el buen Píramo y su amada.

Sus penas y sus dolores cada cual manifestaba, conciertan de verse juntos una noche sosegada junto a una fresca fuente que está del pueblo apartada, y metida entre arboleda 
de unos morales cercada.

Ambos consienten en ello, cada cual da su palabra,

que en llegando a la noche iría a la fuente aplazada.

Aún la noche no es venida, ni la gente sosegada, cuando la hermosa Tisbe se sale disimulada de la casa de su padre sin de nadie ser mirada. Puesta rica basquiña de oro y seda labrada, cuerpo y mangas de brocado y una gorguera cuajada; de aljófar y pedrería la gorguera va esmaltada. No lleva toca ninguna, va en cabello y descofrada, con un manto de cendal la Tisbe va cobijada. Lleva muy gran deseo de se ver allá llegada con Píramo sus amores que ella tanto deseaba. Llegado que hubo a la fuente, se halló desconsolada por verse la triste sola sin aquél que tanto amaba. Allegóse so un moral y allí se estuvo asentada, mirando a una parte y otra por ver si su amor llegaba. Vio venir una leona a la parte dó ella estaba, toda la boca sangrienta y de sed muy fatigada. La Tisbe desque la vido toda se sintió turbada, deja el manto y los chapines por huir apresurada. La leona topó el manto y allí lo despedazaba, y allega y bebe en la fuente y a la hora se tornaba. Píramo, luego, al instante a buscar su linda amada, y llegó junto al moral porque pensó que allí estaba. 
Y viera el manto y chapines, mas no halló lo que buscaba. Vido el manto ensangrentado, sin color se desmayaba, pensando que aquella fiera de aquel monte la matara. Diciendo palabras tristes que a las piedras ablandara: “¿Para qué genero la vida, pues mi Tisbe muerta estaba?».

La espada sacara luego y con ella se matara. La Tisbe como vido la leona no tornaba íbase para la fuente donde Píramo hallara, temblándole todo el cuerpo que el alma se le arrancaba. Como lo vido la Tisbe(95) sobre el cuerpo se desmaya, mesa sus rubios cabellos y su blanca cara rasgaba. Estando en esta sazón el Píramo se traspasa. La doncella, como vido que ya él muerto quedaba, tomó la espada del fuste que el cuerpo le traspasaba. Sin hablar ninguna gran cosa sobre la espada se eschaba, y hubieron fin los amantes porque tan bien se amaban.

\section{[8v][V.] Soneto [Garcilaso de la Vega]}

Estoi contino en lagrimas bañado rrepreso sienpre el layre con sospiros y mas me duele el nunca osar pediros que e uenido por uos a tal estremo

que viendome do estoi a lo que ando por el camjno estrecho de segujros Si me quiero tornar por no huyros desmayo viendo atras lo que pasado

$Y$ asi a subir prueuo la difiçil cunbre ${ }^{76}$

76. Verso de cómputo dodecasílabo. 


$$
\begin{aligned}
& \text { a cada paso espantome en la vian } \\
& \text { enxenplos tristes de los que an caydo } \\
& \text { Y sobre todo falta me la lunbre } \\
& \text { de lesperança con que andar solia } \\
& \text { por la escura rrigion de vuestro olvido }
\end{aligned}
$$

2 [Var. procedente de GLdlV (1995): rompiendo siempre el aire; 4 [que he llegado por vos a tal estado; 5 [lo que he andado; 9 [y si quiero subir a la alta cumbre; 10 [espántanme en la vía; 11 [ejemplos ... han caído; 12 [sobre todo, me falta ya la lumbre; 13 [de la esperanza; 14 [por la oscura región de vuestro olvido

Testimonios: No consta en Las obras de Boscán y algunas de Garcilaso de la Vega: repartidas en cuatro libros, Barcelona, Carles Amorós, 1543, cuya portada revista el privilegio real de Carlos V, tal como en el caso de nuestro manuscrito. De acuerdo a Morros (1995), pp. 318-319, los testimonios más próximos a la vida del poeta son: B77, B89 [Obras del excelente poeta Garcilaso de la Vega. Con anotaciones y enmiendas del maestro Francisco Sánchez ... Pedro Laso, Salamanca 1577 y Diego López y Pedro de Adurza, Salamanca 1589, respectivamente], HT (XXXII) [Fernando de Herrera, Obras de Garcilaso de la Vega con anotaciones, 1580, 204;], C (XXXVII) [Cancionero general de obras nuevas, Zaragoza, 1554, ed. C. Clavería] Mb [Biblioteca de Palacio de Madrid], Mpu2 [BNE], y Ms. [Bibliotèque Nationale de Paris]». Adicionales testimonios son UAM, p. 3101 a, Mss. 3940, fol. 254v, Cancionero de Garcilaso y de Quevedo, s. XVII, Soneto XXXIII; 4256, ff. 256v-257r, cancionero de obras de DDHdM, s. XvII, «De Garcilaso»; XVII MRAE RM 6939, 46. Nos basamos en la lectura ofrecida en Garcilaso, Obra poética y textos en prosa, ed. Morros, Barcelona, Crítica, 1995, 62; Garcilaso, Poesía castellana completa, ed. Rivers, Madrid, Castalia, 1996, 80;

$$
\begin{aligned}
& \text { TRANSCRIPCIÓN MODERNIZADA } \\
& \text { Estoy contino en lágrimas bańado, } \\
& \text { represo siempre el aire con sospiros, } \\
& \text { y más me duele el nunca osar pediros } \\
& \text { que he venido por vos a tal extremo; } \\
& \text { que viéndome do estoy y a lo que he andado } \\
& \text { por el camino estrecho de seguiros, }
\end{aligned}
$$

77. Soneto núm. XXXVIII de Garcilaso, de acuerdo a Garcilaso de la Vega (1995), 62. En su edición de las poesías del poeta toledano, 1577, Herrera le asigna el número XXXII, 208-209. Las variantes son las sigs.: (v. 2) rrepreso (lectura ms. AHPB) vs. rompiendo (ed. Crítica), (v. 3) pediros vs. deciros, (v. 8) pasado vs. dejado, (v. 9) difícil vs. alta, (v. 10) espántanme vs. espántome, (v. 10) vían vs. vía, (v. 12) Y sobre todo faltame la lunbre vs. Sobre todo me falta ya la lumbre. 
si me quiero tornar para huïros

desmayo, viendo atrás lo que he pasado.

Y si a subir pruebo la difícil cumbre,

a cada paso espántanme en la vía

ejemplos tristes de los que han caído.

Y sobre todo fáltame ya la lumbre

de la esperanza, con que andar solía

por la oscura región de vuestro olvido.

\section{[8v][VI.] Soneto [Gutierre de Cetina $]^{78}$}

leandro que de amor en fuego ardia puesto que a su deseo contrastaua el fortunoso mar que no vsaua nadando a su pesar pasar queria

Ya que de su atreuer el premjo via que a la rrabiosa muerte lo tiraua mirando aquella torre a donde estaua $\mathrm{y}$ ero a las fieras ondas se bolvia

a las quales con su enamorada $a^{79}$ dixo pues aplacar furor divino vn uisto desear no puede nada

[9r] Dexadme al fin llegar a este camino pues poco e de tardar y a la tornada secutá vuestra saña en mi destino ${ }^{80}$

78. Obras de Garci Lasso de la Vega con anotaciones de Fernando de Herrera (1580), 204-205: «Cetina, que parece que quiso contender con G. L. en algunos sonetos, hizo este mesmo desta suerte: ["]Leandro, que d'Amor en fuego ardia, / puesto qu'a su desseo contrastava / el fortunoso mar, que no cessava, / nadando a su pesar passar quería. / Mas viendo ya, qu’el fin de su osadia / a la raviosa muerte lo tirava; / mirando aquella torre, adond' estava / Ero, a las fieras ondas se bolvia, / A las cuales con ansia enamorada / dixo, pues aplacar furor divino / enamorado ardor no puede nada; / Dexad m'al fin llegar deste camino, / pues poco é de tardar; i a la tornada / secutad vuestra saña i mi destino." ". En Obras de Gutierre de Cetina (1977), 112, se lee "al fortunoso mar» para el v. 3. Para un repaso brillante de la fama del soneto "Pasando el mar Leandro el animoso» en la edad áurea, consultar Alatorre (1975). Otra lectura imprescindible del mismo filólogo es el de 1956. Bibliografía adicional incluye los sigs. estudios: Cossío (1929) y (1952). Compararse con el «Leandro» de Juan Boscán, de 2.793 vv., en Obras (1991), 417-491.

79. v. decasílabo. Incluso en la Canción IX, de DDHdM (2007), 615-623, vv. 63-70, que se encuentran en la 617, la temática versa sobre Hero y Leandro.

80. Cfr. Garcilaso, 53, soneto XXIX: «Pasando el mar Leandro el animoso, / en amoroso fuego todo ardiendo, / esforzó el viento, y fuese embraveciendo / el agua con un ímpetu furioso. / Vencido del trabajo presuroso, (5) / contrastar a las ondas no pudiendo, / y más del bien que allí perdía 
3 [cessava; 5 [Mas viendo ya qu'el fin de su osadia; 6 [a la raviosa; 9 [con ansia enamorada; 11 [enamorado ardor no; 12 [deste camino; 14 [secutad vuestra saña i mi destino

Testimonios: Gutierre de Cetina, Rimas, ed. Jesús Ponce Cárdenas, Madrid, Cátedra, 2014, no. 112. Gutierre de Cetina. Sonetos y madrigales completos, no. 115. Obras de Gutierre de Cetina, I, 111. "Leandro, que de amor en fuego ardía»; 1557 Cancionero general, 356v (Suplemento, no. 269), sólo coincide con el texto de TCLM 506 en el primer cuarteto; 1570 TCLM 506, 118v (Cancionero sevillano de Toledo, 2006, no. 71); UAM, 3159a, Mss. 2973, 88-89, no. 100, Flores de baria poesía, 1577; 4069, fol. 14v, Poesias de Gutierre de Cetina, s. XIX; 7982, fol. 59r, copia de Flores de baria poesía, "de Çetina».

En Esteban de Nágera, Cancionero general de obras nuevas (Zaragoza, 1554), no. CII, 239, se lee el soneto, «En el soberuio mar se vía metido / Leandro y de sus ondas trastornado / y menos del temor de muerte elado / del del fuego de amores encendido, / quando, de congoxoso y oprimido, / de aliento y fuerça ya desamparado / más que de su morir, y entristecido, / habló d'esta manera, mas fue en vano, / echando ell alma en el postrer acento / d'una cansada voz y dolorida: " $\mathrm{O}$ riguroso mar y ayrado viento! / dexadme adonde voy allegar sano / y luego me ahogad a la venida."». En Cancionero llamado Flor DE enamorados, Barcelona 1562, ed. Antonio Rodríguez-Mońino y Daniel Devoto, Valencia, Editorial Castalia, 1954, ff. 108r-109r, se lee Aqui comiençan los romances notables de oyr sobre hechos Romanos con el de Leandro y Hero: Romance de Leandro: «Por el braço del Esponto [sic] / Leandro va n[a] uegando / sale del puerto de Abido / hazia Sesto caminando / su lindo cuerpo es nauio / el Amor le va animando / sus braços siruen de remos / quel agua van apartando / y los pies por gouernalle / a su trabajo ayudando / por aguja su cabeça / del norte no va curando / la lumbre es el que le llama / por ella se va guiando / derribara el viento aquella / triste curso señalando / solto los vientos Neptuno / el mar anda rodeando / Iupiter rompe sus sellos / muy grande furor mostrando / y el esforçado amador va con animo nadando / la fortuna lo maltrata / con las ondas va luchando / tanto esforçaron los vientos / quel triste va cançando / do empeço con gran dolor deste modo lamentando / O la mi tierra de Abido / que pensaras yo faltando? / O mis parientes y amigos / no me spereys desseando / O la mi señora Hero / que haras dime tu quando, / veras este triste cuerpo / que testaua contemplando / Leandro estando en aquesto / su vida se yua apocando / çabullo el agua al hondo / murio el triste sospirando / y con dezir Hero Hero / si biuir se fue acabando.». Viene seguido del siguiente Romance de Hero (fol. 109r-v): «Aguardando estaua Hero / al amante que

muriendo / que de su propia vida congojoso, / como pudo, 'sforzó su voz cansada / y a las ondas habló d'esta manera, (10) / mas nunca fue su voz dellas oída: / "Ondas, pues no se escusa que yo muera, / dejadme allá llegar, y a la tornada / vuestro furor esecutá en mi vida.”». 
salia / con tristeza y gran cuydado / de ver quan tarde venia / miraua de una ventana / el temporal que corria / por las orillas del mar / sus lindos ojos boluia / y en ver la onda que daua / a la tierra do viuia / pensaua quera Leandro / con la escuridad que hazia / pero en su mirar contino / ya quel alua esclarescia / vido un hombre alli tendido / que muerto le parescia / despues que [h] uuo mirado / conosciole en demasia / quera su amigo Leandro / que amaua mucho y queria / con grandissimo dolor / estas palabras dezia / o desdichada muger / o gran desuentura mia / pues he perdido mi amado / que mas que a mi le queria / bien me priuaste fortuna / del gozo que posseya / ven ya, muerte si quisieres / y darete esta alma mia / viendo mi señor ya muerto / no quiero viuir un dia / y diziendo estas palabras / se echo con gran osadia / desde la ventana a baxo / y encima el cuerpo caya / a Leandro acompañando / la hermosa Hero moria / en los campos Eliseos / Hero y Leandro en compañia / sepultaron juntamente / con tristeza y agonia.». Sepúlveda, cit., ff. 264v-267v, registra esta versión: Romance de Leandro y Hero: "Al pie del mar del Esponto / estaua el fuerte Leandro / sentado en la fria arena / la escura noche aguardando / que alla en el templo de Venus / Hero y el han concertado / que en noche escura \& serena / passasse la mar a nado / porque nadie no supiesse / lo que ellos han concertado / que ella pornia vna lumbre / por do el fuesse guiado / su luz el dia escondiendo / el claro sol declinando / la escuridad todo el mundo / de tenebrura sembrando / y las estrellas luzientes / el alto cielo adornado / y el furioso Fauonio / su rigor algo amansando / en biuas llamas ardiendo / su dulce Hero esperando / desque la vio relumbrar / todo temor desechando / se desnuda sus vestidos / el animoso Leandro / con osadia muy grande / a nado en el mar se echando / nauegaua para sexto / de Abido se va alexandro [sic] / de su cuerpo haze nauio / el solo va nauegando / sus braços siruen de remos / quel agua van desuiando / su cabeça es la guia / que el norte no va mirando / sus piernas por gouernalle / siruen y el va gouernando / derecho va hazia la lumbre / que lexos ella alumbrando / la mar se muestra contraria / los vientos se han leuantado / soplando con gran rigor / la mar han soberuiscado ${ }^{81}$ / grandes sierras hazia el agua / brabosamente sonando / tan altas que parecia / llegar al cielo estrellado / el desdichado mancebo / de tierra muy alongada / boluer no podia Abido [sic] / ni passar del otro cabo / la mas parte de la noche / estuuo ansi peleando / con la mar y con la muerte / por librarse procurando / mas el ayre como crece / la mar mas yua alterando / Leandro siendo de carne / con las olas va lidiando / de cansado congoxoso / aunque fuerte desmayando / a los dioses conuocaua / a todos el suplicando / los ayres y el furor / del mar fuessen amansando / \& mucho mas a Neptuno / que le valiesse rogando / de aquel trago de la muerte / en que staua batallando / tambien a la diosa Venus / desta suerte lamentando

81. $[$ sic $]$ 
/ Valeme diosa señora / socorro yo a ti demando / no me dexes perecer / en este viaje que ando / pues para valer naciste / los que de amores van penando / al cielo alçando sus ojos / algun tanto se animando / con sospiros \& gemidos / començo de nueuo hablando / a llamar su dulce Ero / su ronca boz animando / o Ero seńora mia / si supiesses tu qual ando / dolerte yas [sic] de la muerte / de tu querido Leandro / que en medio la mar salada / estaua testamentando / tu memoria me es aliuio / por te ver ando llorando / por ti me pesa morir / por ti me ando querellando / a las espantosas olas / con ruegos importunando / que se duelan de mi muerte / mi desdicha lamentando / si aportare a tu ribera / por merced te lo demando / que al pie de tu alta torre / sea mi cuerpo sepultado / estas palabras diziendo / en su Ero trasportado / contemplando en su hermosura / del trabajo quebrantado / nombrando el nombre de Hero / el cuerpo se va anegando / Hero que estaua en la torre / con congoxa esperando / a su esposo \& dulce amigo / y su desseado Leandro / estando en esto la triste / en el contino pensando / trasportado en su tardança / adormiose de cansancio / poco le duro el reposo / porque luego en despertando / vio muerto al pie de la torre / a su querido Leandro / como conocio ser el / aunque estaua demudado / \& mordido de los peces / en su cuerpo delicado / llorando de los sus ojos / desta suerte le hablando / Espera mi dulce amigo / \& mi querido Leandro / pues que yo tal amor pierdo / mi muerte tome de grado / no es justo sin vos me quede / pues que tanto me has amado / en mi biuir y morir / mi querer sera mostrado / o mis dioses dadme esfuerço / para visitar mi amado / pues que perdi mi alegria / \& mi bien tan sublimado / en el tenia mi esperança / y tambien el mi cuydado / recibeme lindo amor / pues a ti me voy de grado / mesa[n]do de sus cabellos / la torre a baxo se ha echado / dio encima del cuerpo muerto / que aun no auia espirado / y assi fenecieron juntos / por amor demasiado / alla en el monte Eliseo / estan ambos sepultados, / dentro de vna sepultura / do su nombre es celebrado / si se amaron mucho en vida / su muerte esta por dechado / vn retulo [sic] en su sepulchro / puso el padre de Leandro / escrito con letras de oro / muy sotil y entallado / que dize, sabed amantes / quel que aqui esta sepultado / con corona muy preciosa / del amor fue coronado / la mas rica y sumptuosa / que nunca amador a dado.».

Asimismo en la BNE, constan estos poemas manuscritos dedicados a la fábula: UAM, p. 3159a, Ms. 2244, fol. 61v, «Leandro de la playa se despide», Cancionero del s. XviI; Ms. 3796, ff. 179v-180v, «Leandro en el mar de Abido», Poesías manuescritas 2. 3. s. Xvir. Cancionero de Góngora y de los Argensola; Ms. 4106, fol. 38r-v, «Leandro, no te muestres atrevido», Ramírez Pagán, Floresta de varia poesía, s. XIX; Ms. 9693, «Leandro rompe (con gallardo intento), fol. 195r, Historias diversas de Sevilla y su reynado, s. XviI. La Silva de varios romances, Barcelona, Jayme Cortey, 1561, ed. moderna a cargo de Antonio Rodríguez-Moñino, Valencia, Castalia, 1953, contiene como su no. 56 el romance "Por el brazo de Elesponto", y el Cancionero llamado FLOR DE ENAMORADOS (Barcelona 1562), ed. moderna a cargo de Antonio Rodríguez- 
Moñino y Daniel Devoto, Valencia, Castalia, 1954, contiene los sigs. poemas dedicados a la fábula: fol. 65v, Soneto de Leandro, de Garcilaso, "Passando el mar, Leandro el animoso», fol. 66r, Soneto de la hermosa Hero, «Hero del alta torre, do miraba", y fol. 109r-109v, Romance de Hero, "Aguardando estaua Hero».

\section{TRANSCRIPCIÓN MODERNIZADA}

Leandro, que de amor en fuego ardía, puesto que a su deseo contrastaba, el fortunoso mar que no usaba nadando a su pesar pasar quería. ${ }^{82}$

Ya que de su atrever el premio veía que a la rabiosa muerte lo tiraba, mirando aquella torre adonde estaba y Hero a las fieras ondas se volvía,

a las cuales con su ansia enamorada dijo, pues, «Aplacar, furor divino, un visto desear no puede nada.

«Dejadme al fin llegar a este camino, pues poco he de tardar, y a la tornada ejecutad vuestra saña en mi destino!».

[9r] [VII.] [Anón.] Soneto

hero que ningun dia rreposaua ni las noches durmia ni podia despues que se le fue su alegria Y que de verla tanto se holgaua

consigo a solas se quexaua temiendo que otro amor lo detenia y no el sobervio viento y mal que hazia $\mathrm{y}$ asi con tierno llanto lamentaua

o crudo amor y viento mj enemigo sosiegate pues ues que triste muero por mi leandro y claro amigo

o uera si por otra dexa a ero y lo tiene gozando alla consigo sin memoria de mi que tanto qujero

82. Caso de cacofonía: pesar pasar. 
Testimonio: Ninguno conocido que se sepa.

TRANSCRIPCIÓN MODERNIZADA

Hero, que ningún día reposaba ni las noches dormía ni podía, después que se le fue su alegría y que de verlo tanto se holgaba, consigo a solas se quejaba temiendo que otro amor lo detenía, y no el soberbio viento y mal que hacía, y así con tierno llanto lamentaba:

« $\mathrm{O}$ crudo amor y viento, mi enemigo, sosiégate, pues ves que triste muero por mi Leandro y claro amigo!

« $\mathrm{O}$ verá si por otra deja a Hero, y lo tiene gozando allá consigo ${ }^{83}$ sin memoria de mí, que tanto quiero!».

[9r][VIII.] [Anón.] Soneto

leandro que en amores no se halla ygual ni en el querer mas uerdadero muy mucho mas que si queriendo a ero a quitalle este amor nada bastaua

Y viendo que de uillano gozaua si por el brauo mar no hazia sendero del viento se quexaua quel po[strero] fin de su triste vida le cabsaua

Vençido a su temor tomo la via por el terrible mar enbraueçido lagua y a la cavsa el agonia

postrera de la muerte y consentido hero hero diziendo le salia el alma y en el mar quedo uençido

Testimonio: Ninguno conocido que se sepa.

\section{TRANSCRIPCIÓN MODERNIZADA}

Leändro, que en amores no se hallaba,

83. El sujeto de la frase ha de ser «ella», refiriéndose a la «otra». 
igual ni en el querer más verdadero, muy mucho más que si queriendo a Hero a quitarle este amor nada bastaba.

Y viendo que de villano gozaba, si por el bravo mar no hacía sendero, del viento se quejaba que el postrero fin de su triste vida le causaba.

Vencido a su temor, tomó la vía por el terrible mar embravecido, l'agua ÿ a la causa el agonïa

postrera de la muerte, y consentido, «HHero!», «iHero!», diciendo le salía el alma, y en el mar quedó vencido. ${ }^{84}$

[9v][IX.] [Anón.] Soneto

la gran absençia a ero le cabsaua del su querido amor muy gran tormento creer no pudo que lo cabse el viento Y el brauo y fiero mar que se ensañaua

era tal su deseo que esto estoruaua toda rrazon y todo sufrimiento sin descansar vn punto ni un momento contino sospirando assi hablaua

mi uerdadero amigo mi deseo do se sufre en amor tal tardança según es mi uentura çierto creo

tu cabsa en otro amor la cruel mudança pues tanto tienpo aya que no te veo alabarse a del todo mi esperança

Testimonio: Ninguno conocido.

\section{TRANSCRIPCIÓN MODERNIZADA}

La gran ausencia a Hero le causaba de el su querido amor muy gran tormento, creer no pudo que lo cause el viento y el bravo y fiero mar que se ensañaba.

84. Se percibe aquí acaso un tono satírico leve. 
Era tal su deseo que esto estorbaba toda razón y todo sufrimiento, sin descansar un punto ni un momento contino suspirando assí hablaba:

«Mi verdadero amigo, mi deseo, do se sufre en amor tal tardanza, según es mi ventura cierto creo

tu causa en otro amor la cruel mudanza, pues tanto tiempo haya que no te veo alabarse ha del todo mi esperanza.».

[9v] [X.] [Anón.] Soneto ${ }^{85}$

Quien de cristal el coraçon tuviera Señora para poder solo mostrarte quan lexos esta el alma de engañarte entonçes tu ni el claro creyera

lo que mi fe te dize tan sin arte $\mathrm{Y}$ aquel gran deseo de agradarte con tal mi conjurado alli se viera

mas que hare triste pues conoçido pienso questa mi fe de ti seńora y sabes el peligro de mi vida

Testimonio: Ninguno conocido.

\section{TRANSCRIPCIÓN MODERNIZADA}

¡Quien de cristal el corazón tuviera, señora, para poder solo mostrarte cuán lejos está mi alma de engañarte, entonces tú ni él claro creyera!

lo que mi fe te dice tan sin arte y aquel gran deseo de agradarte

85. Soneto fragmentario. Faltan íntegros los vv. 5, 9-11. 
con tal mi conjurado allí se viera.

$\cdots$
$\ldots$
$\ldots$

Mas, ¿qué haré, triste? Pues conocido, pienso que está mi fe de ti, señora, y sabes el peligro de mi vida.

[10r]

[XI.] [Anón.] Soneto

Quando sera aquel dia uenturoso que buelua yo a mirar aquel diuino senblante y aquel ayre peregrino de tu gra[c]ia y rrostro tan hermoso

cuya menbrança haze ser sabroso el mal que sufre el alma tan contino mas ay tanto trabajo en el camjno que nunca espero uerme tan dichoso

uerna por vnos terminos tan largos si ya viniere a ser lo que yo deseo que no sera posible de erar tanto

la vida que en los pasos tan amargos quando de ti me aparto claro veo que to a de acabar en triste llanto

4 [gracioso rostro; 10 [viniesse ... desseo; 11 [durar tanto; 12 [passos; 13 [conque de ti; 14 [en este llanto

Testimonios: UAM, p. 2972a, Mss. 1132, fol. 6v, Poesías varias (Ms. 1132 de la Biblioteca Nacional de Madrid), "pequeño cancionero de [D]DHdM», ed. Beatriz Entenza de Solare, Buenos Aires, Universidad de Buenos Aires, Facultad de Filosofía y Letras, 1978, no. 4; Esteban de Nágera, Cancionero general de obras nuevas: Zaragoza, 1554, ed. Carlos Clavería, Barcelona, Edicions Delstre's, 1993, no. 143, 274; MP 570, 252. No consta en DDHdM 2007.

\footnotetext{
TRANSCRIPCIÓN MODERNIZADA

¿Cuándo será aquel día venturoso que vuelva yo a mirar aquel divino semblante y aquel aire peregrino de tu gracia y rostro tan hermoso?

Cuya membranza hace ser sabroso el mal que sufre el alma tan contino,
} 
mas, ¡Hay tanto trabajo en el camino que nunca espero verme tan dichoso!

Vendrá por unos términos tan largos si ya viniere a ser lo que yo deseo, que no será posible de errar tanto.

La vida que en los pasos tan amargos cuando de ti me aparto, claro veo que todo ha de acabar en triste llanto.

[10r][XII.] [Diego Hurtado de Mendoza] Soneto a dońa marina de aragon

En la fuente mas clara y apartada del monte el casto coro consagrado vi entre las nueue hermanas asentada vna hermosa ninfa al diestro lado

estaua sin cabellos coronada de verdura y arrayan mezclado en traje estrańo y lengua desvsada dando y quitandole y es a su grado

vi como sobre todas pareçia que no fue poco uer honbre mortal Ynmortal hermosura y boz divina

[10v] Y conoçila ser dońa mariña la quel çielo dio al mundo por señal de la parte mejor que en ti tenja.

5 [cabello; 6 [de verde hiedra y; 8 [quitando leyes a su grado; 14 [si tenia

Testimonios: UAM, p. 3064a, Ms. 2621, fol. 332v, Cancionero de Juan Fernández de Heredia, finales del s. Xvi, contiene también poesías de Montemayor y DDHdM, donde se lee otro soneto a doña Marina de Aragón; Ms. 2973, 83; Ms. 3816, fol. 12v, Cancionero de DDHdM, s. Xviıi; Ms. 3968, fol. 60v, Cancionero de la segunda mitad del s. Xvi; Ms. 4256, fol. 110r-v, Obras en verso y prosa de DDHdM y otros autores, s. XvII; Ms. 4262, fol. 143v, Obras poéticas y algunas en prosa de DDHdM; Ms. 4268, ff. 108v-109r, Poesía y prosa de DDHdM, s. XviI; Ms. 5566, Cancionero obras de Cornejo y poemas de DDHdM, s. XVII y XVIII; 7982, fol. 55r-v, Flores de baria poesía; (12) «En la fuente más clara y apartada», DDHdM, Poesía completa, Soneto V, 124.

TRANSCRIPCIÓN MODERNIZADA

En la fuente más clara y apartada del monte el casto coro consagrado vi entre las nueve hermanas asentada 
una hermosa ninfa al diestro lado.

Estaba sin cabellos coronada

de ventura y arrayán mezclado,

en traje extrańo y lengua desusada

dando y quitándole, y es a su grado.

Vi cómo sobre todas parecía

que no fue poco ver hombre mortal

inmortal hermosura y voz divina.

Y conocíla ser doña Marina,

la que el cielo dio al mundo por señal

de la parte mejor que en sí tenía. ${ }^{86}$

\section{[10v][XIII.] Soneto [DDHdM]}

basto la vida en males y amor creçe creçi en males amor y alli se cria ${ }^{87}$ mi alma se esfuerça y hazerse ofreçe de sus penas costunbre y conpañía

no me espanto de uida que padeçe tan braua servidunbre y que porfia mas espantome como no enloqueçe con el bien que vee en otros cada dia

en dura lei en conoçido engaño huelga el triste de viuir y tu que le persigas la paçiençia

o cruel pena o aspera sentençia que por fuerça me muestra a sufrir los plazeres ajenos y mi daño

2 [creçe en; 10 [huelga triste señora de vivir; 12 [o cruda tema; 13 [muestren

Testimonios: UAM, p. 3112a, Mss. 2621, fol. 333r; 2973, ff. 83-84, DDHdM; 4268, ff. 109r-v; 3816, fol. 5r, DDHdM, Obras poéticas, s. XviII; 3968, ff. 60v-61r, Cancionero de la segunda mitad del siglo Xvi; 425, ff. 110v-111r, Obras en verso y prosa de DDHdM y otros autores; 4262, fol. 144r, Obras poéticas y algunas en prosa de DDHdM, s. Xvir; 7982, fol. 55v, Copia del Ms. Flores de barias poesía, México, 1577; "Gasto la vida en males y amor crece», DDHdM, Poesía completa (2007), 126.

86. Cambio de focalización de la tercera a la segunda persona.

87. creçe / creçe, error por homeoteleutón. 


\section{TRANSCRIPCIÓN MODERNIZADA}

Gasto la vida en males y amor crece, crece en males amor, y allí se cría, mi alma se esfuerza y hacerse ofrece de sus penas costumbre y compañía.

No me espanto de vida que padece tan brava servidumbre y que porfía, mas espántome cómo no enloquece con el bien que ve en otros cada día.

En dura ley, en conocido engaño huelga el triste de vivir, y tú, que le persigas la paciencia;

¡O cruel pena! ¡O áspera sentencia! ¡Que por fuerza me muestra a sufrir los placeres ajenos y mi dańo!

[10v] [XIV.] [De DDHdM] Soneto

buelue el çielo y el tienpo huye y calla y despierta callando tu tardança creçe el deseo mengua la esperança tanto mas quanto mas lexos te halla

mi alma es hecha canpo de batalla [con] baten el rreçelo y la esperança asegura la fe toda mudança avnque sospechas andan por mudalla

Yo sufro y callo y digote senora

[11r] O cuando sera aquel dia bien beni[do] que me ueras contento en tu presençia

rrespondeme tu saña matadora si juzgas lo que a de ser por lo que a sido que menor es tu mal estando absente

2 [y callando despierta; 3 [y buelue ... ; 10 [dia que estare; 11 [libre desta contienda en; 13 [si juzga ... que fue

Testimonios: UAM, p. 3409a, Ms. 2621, fol. 331v, Cancionero de Juan Fernández de Heredia; 2973, 82, Flores de baria poesía, México, 1577, atribuido a Cetina como soneto inédito; Ms. 3816, fol. 11r, DDHdM, s. XviII; 3968, fol. 60r, Cancionero de la segunda mitad del s. Xvi; Ms. 4256. ff. 109v-110r, DDHdM, 
s. XviI; Ms. 4262, fol. 142r, DDHdM, s. XviI; Ms. 4268, fol. 108v, DDHdM, s. XvII; Ms. 7982, fol. 54v, Copia, Flores de baria poesía; «Vuelve el cielo y el tiempo huye y calla», DDHdM (2007), 122. Jauralde Pou (2009), 517-519.

TRANSCRIPCIÓN MODERNIZADA

Vuelve el cielo y el tiempo huye y calla y despierta callando tu tardanza, crece el deseo, mengua la esperanza tanto más cuanto más lejos te halla.

Mi alma es hecha campo de batalla, combaten el recelo y la esperanza, asegura la fe toda mudanza aunque sospechas andan por mudalla.

Yo sufro y callo y dígote, señora, « $\mathrm{O}$ ! ¿Cuándo será aquel día bienvenido que me verás contento en tu presencia?

Respóndeme tu saña matadora si juzgas lo que ha de ser por lo que ha sido, que menor es tu mal estando ausente.».

[11r]

[XV] Soneto [DDHdM]

Agora en la dulçe sçiençia enbraveçido aora en el vso de la ardiente espada aora con la mano i sentido puesto en segir la caça leuantada aora el pesado cuerpo este durmiendo aora el anjma atenta y desuelada sienpre en el coraçon terne esculpido tu ser y hermosura entretallada

entre jentes estrañas do se ençierra el sol fuera del mundo y se desuia biuire y morire sienpre deste arte

en el mar en el çielo so la tierra contenplare la gloria de aquel dia que mi uista figura en toda parte

1 [embebecido; 6 [alma; 11 [durare y permaneceré; 14 [tu vista

Testimonios: UAM, 2874a, Mss. 2973, 82-83, Son. de DDHdM; 4256, fol. 110 , Obras en verso y prosa de DDHdM y otros a autores, atrib. a DD- 
HdM; 7982, ff. 54v-55r, Copia del Ms. Flores de baria poesía, México, 1577; "Agora en la dulçe fuençia enbraveçido" ('Ahora en la dulce fuenda embravecido') y "Ahora en la dulce ciencia embebecido», DDHdM (2007), 123.

\section{TRANSCRIPCIÓN MODERNIZADA}

Ahora en la dulce ciencia embravecido, ahora en el uso de la ardiente espada, ahora con la mano y el sentido puesto en seguir la caza levantada;

ahora el pesado cuerpo esté durmiendo, ahora el ánima atenta y desvelada, siempre en el corazón tendré esculpido tu ser y hermosura entretallada.

Entre gentes extrañas do se encierra el sol fuera del mundo y se desvía viviré y moriré siempre deste arte.

En el mar, en el cielo, so la tierra contemplaré la gloria de aquel día que mi vista figura en toda parte.

[11r][XVI] [Anón.] Soneto

Si pudiese bastar el bien amaros aqui de mi qujsiese desdoleros esperança ternia a como ueros $\mathrm{y}$ en alguna manera a ablandaros

pero poco aprouecha desearos pues claro no puedo mereçeros y si tubiese esperança de alcançaros bastaua contentarme solo ueros

[11v] $\mathrm{m}$ [a]s tengo tant salud o confiança de alcançar este bien por esta via que ya voi perdiendo la esperança

Y pues que tal bien con tal pena se alcança quiero asi esperar anima mia el bien tan deseado de bonança

Testimonio: Ninguno conocido. 


\section{TRANSCRIPCIÓN MODERNIZADA}

Si pudiese bastar el bien amaros aquí de mí quisiese desdoleros, esperanza tendría a como veros y en alguna manera a ablandaros.

Pero poco aprovecha desearos, pues, claro, no puedo mereceros, y si tuviese esperanza de alcanzaros bastaba contentarme sólo veros.

Mas tengo tanta salud o confianza de alcanzar este bien por esta vía que ya voy perdiendo la esperanza.

$Y$, pues, que tal bien con tal pena se alcanza quiero así esperar, ánima mía, el bien tan deseado de bonanza.

[11v][XVII] [Cetina] Soneto de don diego de men doça a vn rretrato de vna dama ${ }^{88}$

Pinzel diuino uenturosa mano perfeta abilidad vnica y rrara conçeto altiuo do si la enbidia avara te piensa enmendar presume en vano

delicado matiz quel ser vmano los muestra qual el çielo lo mostrara beldad tuya beldad se ue tan clara que al ojo engańa el arte soberano artifiçe engenjoso que sentiste quando tan cuerdamente contenplauas el sujeto que muestran tus colores

laso si como yo la uiste el pinzel y la tabla en que pintauas $\mathrm{Y}$ tu como no ardeis qual yo de amores

3 [do la; 4 [si te; 6 [nos muestra; 7 [cuya; 12 [Dime, si como yo la vi, la viste.

Testimonios: UAM, 3253b, «Pincel divino, venturosa mano», Ms. 2973, 134, Flores de baria poesía, atrib. a Cetina; Ms. 4069, fol. 53r-v, Poesías de Gu-

88. Al conformarnos con el criterio de A. Blecua, 204-205, el poeta menos conocido, i.e. Cetina, tendría que ser su autor. 
tierre de Cetina, s. xIx; Ms. 7982, ff. 89v-90r, Copia de Flores de baria poesía; Cetina 1981, no. 51, 128; Cetina, 2014, no. 50, 306.

\section{TRANSCRIPCIÓN MODERNIZADA}

Pincel divino, venturosa mano, perfecta habilidad única y rara, concepto altivo do la envidia avara

[si] te piensa enmendar, presume en vano.

Delicado matiz que el ser humano nos muestra cuál el cielo lo mostrara, beldad tuya, beldad se ve tan clara, que al ojo engańa el arte soberano.

Artífice ingenioso, ¿qué sentiste cuando tan cuerdamente contemplabas el sujeto que muestran tus colores?

Laso, si como yo la vi la viste el pincel y la tabla en que pintabas, y tú, ¿Cómo no ardéis, cual yo, de amores?

[11v][XVIII] Soneto del mjsmo [¿ंCetina?] a vna la bradora

$[12 \mathrm{r}]$

En vn rrustico uestir y gran baxesa $\mathrm{d}[\mathrm{e}]$ vaxo de vn saluatico tocado natura nos mostro de lo arado la suma perfiçion de la belleza

o quan atras se queda la grandeza Vençida de con seruil y baxo estado tanbien a lo presente y a lo pasado quexo solo dexo naturaleza

$\mathrm{Y}$ yo mas que todos quexar me quiero de aqueste duro y fino diamante metido en vn metal baxo y grosero

pues mjs lagrimas no an sido parte a enterneçer el coraçon de azero deste divino y anjelico senblante

Testimonio: Ninguno conocido. El soneto no consta ni en la ed. de poesías de Cetina a cargo de López Bueno ni en la de Ponce Cárdenas. Como se lee «del mjsmo» en el cuaderno de versos, se adscribe entonces autoría a Cetina, poeta responsable por el número anterior. 


\section{TRANSCRIPCIÓN MODERNIZADA}

En un rústico vestir y gran bajeza debajo de un salvátivo tocado natura nos mostró de lo arado la suma perfección de la belleza. ${ }^{89}$

¡O cuán atrás se queda la grandeza vencida de servil y bajo estado!

También a lo presente y a lo pasado quejo solo, dejo naturaleza.

Y yo más que todos quejar me quiero de aqueste duro y fino diamante metido en un metal bajo y grosero.

Pues mis lágrimas no han sido parte a eternecer el corazón de acero de este divino y angélico semblante.

\section{[12r] [XIX] [Montemayor] Soneto del mjsmo}

Los ojos no pecaron en miraros si no pretenden mas que solo ueros si el alma a presumido mereceros no la querais mas mal que desearos

jamas dexo mi alma de hablaros sin pensamiento alguno de moueros si mjs lagrimas piensan deteneros podeys me lo pagar con no ablandaros

mas no me deys por fin vuestra partida que avnque en estremo sea el descontento con ueros pasare mi triste uida que no ueros esta el dolor que siento y el alma que se ue por uos perdida no quiere mayor bien que su tormento

3 [pretendido; 4 [le; 5 [dexe mi lengua; 7 [deteneros; 8 [se lo; 9 [Mas no deis; 10 [y aunque; 12 [Pues no hay vida sin vos, ni yo la siento; 13 [se vio; 14 [se gana solo en fe de su tormento

89. Compárese con la descripción de la rústica Dorotea en Don Quijote I, 28. 
Testimonios: «Los ojos no pecaron en miraros», La Sociedad de Bibliófilos Españoles, El Cancionero del poeta George de Montemayor, ed. Ángel González Palencia, Madrid, 1932 [orig. Anvers \{Amberes\}, 1554\}], Montemayor, Cancionero, $1554,30 \mathrm{v}=$ p. 45 : «Los ojos no pecaron en miraros, / si no pretenden más que solo veros, / si el alma ha pretendido mereceros, / no le queráis más mal que desearos. / Iamás dexe mi lengua de hablaros / sin pensamiento alguno de moveros; / si mis lágrimas piensan deteneros / podéis se lo pagar con no ablandaros. / Mas no deis por fin vuestra partida, / y aunque en extremo sea el descontento, / con veros pasaré mi triste vida. / Pues no hay vida sin vos, ni yo la siento, / y el alma que se vio sin vos perdida, / se gana solo en fe de su tormento.». También consta en Jorge de Montemayor, Poesía selecta, ed. Juan Montero y Elizabeth Rhodes, Madrid, Castalia, 2012, no. 39, 137.

\section{TRANSCRIPCIÓN MODERNIZADA}

Los ojos no pecaron en miraros si no pretenden más que sólo veros, si el alma ha presumido mereceros no la queráis más mal que desearos.

Jamás dejó mi alma de hablaros sin pensamiento alguno de moveros, si mis lágrimas piensan deteneros podéis me lo pagar con no ablandaros.

Mas no me deis por fin vuestra partida, que aunque en extremo sea el descontento con veros, pasaré mi triste vida.

Que no veros está el dolor que siento y el alma que se ve por vos perdida no quiere mayor bien que su tormento.

\section{[12r] [XX] [Montemayor] Soneto}

O yngrato amor quien no te conoçiese dulçor amargo quien no te gustase [12v] genero femenil quien se apartase de tu falsa opinion y alli muriese

o gozo uariable $\mathrm{Y}$ quien pudiese antes desesperar que no esperase o vmana hermosura y quien çegase primero que en mirar mas çiego fuese no juzge nadie por lo que digo que amor es contra mi pues ya no siento 
njnguna enfermedad de amor comigo
no es fuerça de dolor mi pensamjento
es fuerça de uerdad y por testigo
presento a quien paso por su tormento

1 [Ingrato; 2 [y quién; 5 [gozo tan variable; 6 [que en ti esperase; 9 [juzgue ... no, por; 10 [amor es ... aunque yo siento; 11 [la dura enfermedad; 12 [dolor, no descontento

Testimonio: $\mathrm{O}$ ingrato amor, quien no te conociese! Montemayor, Cancionero, 1932 [1554], no. 32, 59: «iIngrato amor, quién no te conociese! / ¡Dulçor amargo, y quién no te gustase! / ¡Género femenil, quién apartase, / de tu falsa opinión, y allí muriese! / ¡Oh gozo tan variable, y quién pudiese / antes desesperar que en ti esperase! / ¡Oh humana hermosura, y quién cegase / primero, que en mirar más ciego fuese! / No juzgue nadie, no, por lo que digo / que amor es contra mí, aunque yo siento / la dura enfermedad de amor conmigo. / No es fuerça de dolor, no descontento, / es fuerça de verdad y por testigo / presento a quien pasó por su tormento.».

\section{TRANSCRIPCIÓN MODERNIZADA}

$¡ \mathrm{O}$ ingrato amor! ¡Quién no te conociese!

¡Dulzor amargo! ¡Quién no te gustase!

¡Género femenil quién se apartase

de tu falsa opinión y allí muriese!

¡O gozo variable! ¡Y quién pudiese

antes desesperar que no esperase!

¡O humana hermosura! ¡Y quién cegase

primero que en mirar más ciego fuese!

No juzgue nadie por lo que digo que amor es contra mi pena, ya no siento ninguna enfermedad de amor conmigo.

No es fuerza de dolor mi pensamiento; es fuerza de verdad, y por testigo presento a quien pasó por su tormento.

[12v] [XXI] [Atribuido a DDHdM] Soneto

mjs ojos de llorar estan cansados mi lengua de quexarse adelgazada mi uida esta tan çerca de acabada quan lexos de rremedio mjs cuidados 


$$
\begin{aligned}
& \text { exenplo soi de muchos desdichados } \\
& \text { comigo qualquier pena es consolada } \\
& \text { Y vos siendo mujer no estais cansada } \\
& \text { de lo que estan mill honbres lastimados } \\
& \text { en el ser de beldad estais pujante } \\
& \text { en esto y en lo demas lleuais corona } \\
& \text { uos sois el fin de toda la hermosura } \\
& \text { mas braua sois comigo que no leona } \\
& \text { mas dura sois señora que no diamante } \\
& \text { y mas hermosa sois que braua y dura }
\end{aligned}
$$

5 [consuelo soy; 7 [con ser mujer; 9 [De tal dureza no hay quien no se espante; 10 [de crueldad que jamas no perdona; 11 [principio y fin de hermosura; 12 [mas dura sois señora que diamante; 13 [mas brava sois señora que leona

Testimonios: UAM, 3192a, «Mis ojos de llorar están cansados», Mss. 2973, 399, anón., Flores de baria poesía, México, 1577; ibid., 400, «Oda glosando el soneto pasado»; 7982, fol. 265r-v, anón., Copia de Flores de baria poesía; DDHdM (2007), son. XI, 526 (atribuido).

\section{TRANSCRIPCIÓN MODERNIZADA}

Mis ojos de llorar están cansados, mi lengua de quejarse adelgazada, mi vida está tan cerca de acabada cuan lejos de remedio mis cuidados.

Ejemplo soy de muchos desdichados, conmigo cualquier pena es consolada, y vos, siendo mujer, ¿no estáis cansada de lo que están mil hombres lastimados?

En el ser de beldad estáis pujante, en esto y en lo demás lleváis corona, vos sois el fin de toda la hermosura.

Mas brava sois conmigo que no leona, más dura sois, señora, que no diamante y más hermosa sois que brava y dura.

[12v][XXII] [Anón.] Soneto a vna dama de palacio que se quiso meter monja en san ta cataljna ${ }^{90}$ y tornose a palaçio

90. Para la actividad literaria llevada a cabo en el Convento de Santa Catalina, ver la n. 46 supra. 
[13r] quan mal parece al mundo vn movimj[ento] vn ya no quiero ser monja o teatina para vn coraçon triste que se fina siguiendo tras el fin del pensamiento mal aya el abadesa y el conuento pues no se por que cabsa determina hazer palaçio a santa catalina uençiendo rrelijion al casamiento

Ya no ay amor ya muertas son las llamas ya biue ypocresia y las lishonjas ya el uelo a les cofi[as] eçede el modo

de oi mas vejonas monjas bolueos damas pues damas tan hermosas se hazen monjas $\mathrm{y}$ asi andara al rreues el mundo todo

Testimonio: Ninguno conocido.

\section{TRANSCRIPCIÓN MODERNIZADA}

Soneto a una dama de palacio que se quiso meter monja en Santa Catalina, y tornóse a palacio

¡Cuán mal parece al mundo un movimiento! ¡Un «iYa no quiero ser monja o teatina!», para un corazón triste que se fina siguiendo tras el fin del pensamiento!

¡Mal haya el abadesa y el convento!

¡Pues no sé por qué causa determina hacer palacio a Santa Catalina venciendo religión al casamiento!

¡Ya no hay amor! ¡Ya muertas son las llamas! ¡Ya vive hipocresía y las lisonjas! ¡Ya el velo a las cofias excede el modo!

¡De hoy más, vejonas monjas, volveos damas, pues damas tan hermosas se hacen monjas! ¡Y así andará al revés el mundo todo!

[13r] [XXIII] [Anón.] Soneto

Ero de vna fatiga congoxosa que lo interior del alma fatigaua con llantos y solloços se quexaua pensando rreposar mas no rreposa 
a su leandro ella como esposa ${ }^{91}$

o dulçe dulçe esposo lamentaua

$\mathrm{Y}$ en esto muy clara muestra daua de uerdadero amor sin faltar cosa

Y como a su llamar no rrespondia creçiendo con furia su tormento con ansia del dolor se amorteçia

dando del calor vn rresfriamjento

[13v] que muerta ya del todo pareçia sin de vida tener algun aliento

Testimonio: Ninguno conocido.

\section{TRANSCRIPCIÓN MODERNIZADA}

Hero, de una fatiga congojosa que lo interior del alma fatigaba, con llantos y sollozos se quejaba pensando reposar, mas no reposa.

A su Leandro ella como esposa «OH dulce, dulce esposo!» lamentaba, $y$ en esto muy clara muestra daba de verdadero amor sin faltar cosa.

Y como a su llamar no respondía, creciendo con furia su tormento, con ansia del dolor se amortecía;

Dando del calor un resfriamiento, que muerta ya del todo parecía, sin de vida tener algún aliento.

\section{[13v][XXIV] [Anón.] Soneto}

hero con amorosas lagrimas lloraba la tenpestad tan grande que hazia en ver que por su cabsa no uenja aquel su dulçe esposo que esperaba rrequiebros sabrosisimos pasaua

91. Ver Museus / Museo, Hero y Leandro, Alcalá de Henares, ¿1514? y Venecia y Florencia 1494 o 1495 . 
consigo sola alla en su fantasia estimulos de su absençia alli sentia çelosos pensamjentos sospechaua

de rrato en rrato a la mar miraba $Y$ en verla tenpestuosa se aflejia $\mathrm{Y}$ a su llanto de nueuo se tornaua

con fatigada boz alli dezia quando sera que vea desdichada aquel vnico bien del alma mja

Testimonio: Ninguno conocido. Sin embargo, Cfr. UAM, 3124b, «Hero con alaridos rompe el cielo», Mss. 4106, fol. 39r-v, Diego Ramírez Pagán, Floresta de varia poesía, s. XIX; "Hero, que el mar donde su bien espera», Ms. 3913, fol. 27r, Libro de differentes y varias poesías / Parnaso español, 2, s. XvII; Ms. 4106, fol. 38r$\mathrm{v}$, que contiene «cuatro sonetos en la triste tragedia de Leandro y Hero, Leandro habla consigo mismo»: "Leandro, no te muestres atrevido ...», A la muerte de Leandro, "Hacia Sesto Leandro navegaba», A la muerte de Hero, "Hero con alaridos rompe el cielo», En la sepultura de Leandro y Hero, orilla de el mar, "Oh, tú, que vas tu vía caminando ...», Ms. 9693, fol. 195r, "Leandro rrompe (con gallardo intento)», y fol. 195v, «Cuerpo de Dios, Leandro enterneçido».

TRANSCRIPCIÓN MODERNIZADA

Hero con amorosas lágrimas lloraba la tempestad tan grande que hacía en ver que por su causa no venía aquél su dulce esposo que esperaba.

Requiebros sabrosísimos pasaba consigo sola allá en su fantasía, estímulos de su ausencia allí sentía, celosos pensamientos sospechaba.

De rato en rato a la mar miraba, y en verla tempestuosa se afligía, y a su llanto de nuevo se tornaba.

Con fatigada voz allí decía:

«¿Cuándo será que vea desdichada

aquel único bien del alma mía?».

Compárese con el son. XXIX de Garcilaso: «Pasando el mar Leandro el animoso, / en amoroso fuego todo ardiendo, / esforzó el viento, y fuése embravecien- 
do / el agua con un ímpetu furioso. / Vencido del trabajo presuroso, / contrastar a las ondas no pudiendo, / y más del bien que allí perdía muriendo / que de su propia vida congojoso, / como pudo, 'sforzó su voz cansada / y a las ondas habló d'esta manera, / mas nunca fue su voz dellas oída: "Ondas, pues no se escusa que yo muera, / dejadme allá llegar, y a la tornada / vuestro furor esecutá en mi vida."”. [13v][XXV] [Anón. ¿Cetina? ¿Juan de Vadillo?] Soneto ${ }^{22}$

Estando naturaleza deseosa de toda perfiçion sacar dechado la ydea quiso mirar de lo criado $\mathrm{Y}$ escojio lo mejor de cada cosa

tomando la frescura de la rrosa

del hermoso rrubi lo colorado

Y el lustre del cristal mas bien labrado

Y el blanco de la perla mas preçiosa

del sol tomo su claro rresplandor

Y el rretrato saco de la belleza

[14r] Y de lo intimo saco su gran ualor

Y asi uiendo tal ser y tal belleza

$y$ tan sin enmienda su lauor

de si se enamoro naturaleza

1 [la Natura; 2 [hazer; 3 [a la ydea miró; 6 [y del claro rubí; 7 [y el lustre; 8[y el; 10 [retracto; 11 [en la persona de Doña Lenor; 12 [Y visto tanto ser y tal grandeza; 13 [tan claro y esmerado su primor; 14 [della

Testimonios: Cancionero sevillano de Toledo: ms. 506 (fondo Borbón-Lorenzana), Biblioteca Castilla-La Mancha, eds. José J. Labrador, Ralph DiFranco, Juan Montero, Universidad de Sevilla, 2006, 240, 339; 1570-1580 MRAE RM 2155-1, 14v; 1577 MN 2973, 215, Soneto de Lagareo (Flores de varia poesía, no. 290); 1585 MP 531, 24v (Cartapacio de Francisco Morán, núm. 145); 1585 PN Esp. 373, 255, A una dama llamada doña Leonor; 1590 MP 1580, 31v, 250; Lucas de Torre, «Algunas notas para la biografía de Gutierre de Cetina, seguida de varias composiciones suyas inéditas», BRAE, 11 (1924), 388-407, 601-626, aquí de interés la 602. En Rico García, Diccionario filológico, ed. P. Jauralde (2009), 242, López Bueno no lo considera obra de Cetina.

92. Juan José Tabada http://www.tablada.unam.mx/poesia/ensayos/enigma.html, 28/09/2014, menciona que Lucas de la Torre (BRAE 1924) lo incluye «entre los inéditos». Consta en el Cancionero Sevillano de Toledo, cit. Ni López Bueno (1984) ni Ponce Cárdenas (2014) lo incluyen en sus respectivas obras. 


\section{TRANSCRIPCIÓN MODERNIZADA}

Estando naturaleza deseosa de toda perfección sacar dechado, la idea quiso mirar de lo criado y escogió lo mejor de cada cosa.

Tomando la frescura de la rosa, del hermoso rubí lo colorado, y el lustre del cristal más bien labrado, y el blanco de la perla más preciosa.

Del sol tomó su claro resplandor y el retrato sacó de la belleza, y de lo íntimo sacó su gran valor.

Y así, viendo tal ser y tal belleza, $y$ tan sin enmienda su labor de sí se enamoró naturaleza.

[14r] [XXVI] [¿̨Pedro de Guzmán?] epístola [Tercetos encadenados, poema fragmentario]

Salud libea meliso enbia si aquel que la suya le destruye al[eue] serle otorgada por alguna via porque premites que asi el viento lleue la fe y la palabra que me diste haziendo tu tornada çierta y breue pasado es el tienpo que me prometiste de ser uenido pero avn no te ueo pues devrias de uenjr sino moriste las oras cuento y en njnguna creo que deua de llegar que pueda verte segun lo que en mi haze tu deseo primero llegara la de mi muerte que la de tu plazer pues que te plaze darme tal galardon por bien quererte Si el morir mjo a ti te satisfaze mi anima yra muy descansada que biviendo enojarte me desplaze acuerdate meliso quan amada vn tienpo fue de ti que tu dezias mi alma sea sola y condenada Y sin uentura y tristes los mjs dias

[14v] En este amante amar libea mi bien y mi esperança y alegria pues como sufrire yo que posea 


la gloria deste nonbre que me dauas
otra que ni lo ame ni le crea
cuerdate que en arbores dexauas
escrito el nonbre mio que creçiendo
mi memoria subias y ensalçaas
las nueuas que me da uan deshaziendo
mi uida y mi salud que tu a marfira
amas y mas que a ti no te qujriendo
y lo peor es que ella sospira
por otro amante y a ti aborreçe
mas el que mucho ama poco mira
pues bien veo yo que no mereçe
ser dexada de ti quien te ama tanto
por mas hermosa queste pareçe
que aunque si me tiene triste llanto
toda disfigurada y aflijida
no huye quien me mira con espanto
quien te uido a ti hazer la despedida
que hazias tu de mi quien lo pensara
segun llorada fue y sentida
de tus lagrimas qujenqujera se engañara
Y de aquellos sospiros tan ardientes
avnque no te quisiera ni te amara
quanto mas yo que miedo de parientes

1 [Salud Libea a Meliso embia; 2 [si al que la suya destruye aleve; 4 [¿’Por qué te plaze que; 5 [la palabra y la fe que tú me diste; 7 [Pasado a; 8 [venido mas aun; 9 [pues bien debrías venir; 10 [y ninguna creo; 11 [que tiene de llegar que pueda verte; 14 [a la de; 16 [El morir; 17 [mi alma partirá; 18 [que enojarte viniendo; 20 [fui de ti; 21 [mi alma sea sola y condenada; 23 [quando dejare de amarte yo, Libea,; 24 [y alegrías; 27 [ni lo ame ni te crea; 28 [Acuérdate; 30 [crezía y ensalsauas; 31 [las nuevas que me dan van desaziendo; 32 [de que a Marfira; 33 [amas, y a más que a ti no te queriendo; 34 [y lo que mejor es, que sospira; 35 [ella por otro amante y te aborreze; 37 [Debrías de mirar que no mereze; 39 [por más hermosa que ella te pareze; 40 [me tiene ansí mi triste llanto; 43 [quien te vio hazer de ti la despedida; 44 [que hiziste de mí,; 45 [sigún de ti fue llorada; 46 [de tus llantos

Testimonios: UAM, 3314a, Ms. 1132, ff. 3v-6r, Poesías varias y pequeño cancionero de DHdM, s. XVII; Ms. 2621, ff. 283r-285v, Cancionero de Juan Fernández de Heredia, finales del s. XvII; Ms. 3902, ff. 41r-44r, Cancionero de poesías varias s. XVI (1550-1560), no. 41, Carta 2 (Cancionero de poesías varias, núm. 42); Ms. 1132, fol. 3v, Epistola (Poesías varias, no. 3, 1560); Ms. 1560 OA 189, 20v, Carta de Libeo a Meliso «Salud, Libea, a ti Meliso enbía»; Ms. 1570

93. A partir de este punto faltan los restantes 53 vv. hasta e inclusive el v. 103 de su versión íntegra, incluida dentro.. 
TCLM 506, 3 (Cancionero sevillano de Toledo, 2006, no. 2); Ms. 1570 MP 617, 237, Epistola de Garçilaso de la Vega (Cancionero de poesías varias, no. 360); Ms. 1580 PN Esp. 307, 1, Carta de Libea a Meliso; Ms. 1590 MN 2621, 283, con la respuesta "El sin salud Meliso a su Libea»; Contrahecho a lo divino de «Salud Libea a Meliso envía», "Salud el alma a su Dios envía»; Ms. 1590 MRAE RM 6226, 229, Carta del alma a Dios en tercetos. Entenza de Solare, Poesías varias (1978), 35-38, destaca la relación que hay entre esta composición y la que empieza «Si no me engaño aquí cerca era», no. 18 del mismo cancionero, 57 ss., donde señala las variantes de las diversas versiones. Entenza también añade a la lista de otros cancioneros donde consta la epístola el Ms. 189 (Oxford, All Soul's College), ff. 20v ss., y el Ms. 307 (Bibliothèque Nationale de Paris), ff. 1 ss. Cf. la Epístola XI, de DDHdM, 396, que comparte afinidades con ésta.

A continuación la lectura según la ed. completa ofrecida por Entenza de Solare:

\section{Epístola}

Salud Libea a Meliso embía, si al que la suya le destruye debe ser otorgada por alguna vía.

¿Por qué te plaze que ansí el viento lleue la palabra y la fe que tú me diste, haziendo tu tornada cierta y breue?

Pasado a el tiempo que me prometiste de ser venido, mas aun no te veo; pues bien debrías venir si no moriste.

Las horas cuento y ninguna creo que tiene de llegar que pueda verte, sigún lo que en mí haze tu deseo.

Primero llegará la de mi muerte y la de tu plazer, pues que te plaze darme tal galardón por bien quererte.

El morir mío a ti te satisfaze; mi alma partirá muy descansada, que enojarte viniendo me desplaze.

Acuérdate, Meliso, quán amada vn tiempo fui de ti, que me dezías: «Mi alma sola sea condenada,

y sin ventura y tristes los mis días, quando dejare de amarte yo, Libea, 
mi bien y mi esperanza y alegrías.»

Pues, ¿cómo sufriré yo que posea

la gloria deste nonbre que me dauas otra que no te ame ni te crea?

Acuérdate que en árboles dejauas escrito el nonbre mío, que creziendo mi memoria crezía y ensalsauas.

Las nueuas que me dan van desaziendo mi vida y mi salud, de que a Marfira amas, y a más que a ti no te queriendo, y lo que mejor es, que sospira ella por otro amante y te aborreze; mas el que mucho ama poco mira.

Debrías de mirar que no mereze ser dejada de [ti] quien te ama tanto, por más hermosa que ella te pareze;

que aunque me tiene ansí mi triste llanto, toda desfigurada y aflijida, no huye quien me mira con espanto.

Quien te vio hazer de ti la despedida que hiziste de mí, quién lo pensara, sigún de ti fue llorada y sentida.

De tus llantos quien quiera se engañara, y de aquellos sospiros tan ardientes, aunque no te quisiera ni te amara;

quanto más yo, que miedo de parientes, ni de honrra, ni de vida, ni del cielo, me hizo rezelar inconuenientes.

¿Dónde están las promesas y el consuelo que me dauas a mí quando te iuas, asigurando siempre mi rezelo,

"Libea», diziendo, "cata que me escribas, escríbeme si quieres que no muera", lágrimas de tus ojos derramando uiuas?

Fáçil te fue engañar a quien creyera, solo en dezillo tú, que no avía estrella en el çielo que sol ni lunbre diera.

Holgaste de engañar vna donzella de quien ya señor eras verdadero, 
que alguna hora te dio descanso vella.

¿Quál dios permite, pues yo por ti muero, que no te duelas de vn dolor tamańo? Mas si ay justitia en el cielo, espero que avré venganza deste mal estraño, tan grande y cruda, que te avré manzilla, aunque no la mereze ya tu engaño.

Mi pena es tanta, que pensar dezilla es imposible aunque esta sea larga, que ni puedo contalla ni escrebilla;

que esta miserable vida amarga, cuyos despojos te harán contento, saldrá muy presto desta dura carga.

No quiero más palabras dar al viento, y pues las que me diste se a lleuado, lleuarse a con ellas mi tormento, y este tan crudo amor mal empleado, principal causa fue de mi mal andanza y deste tan bajo y tan triste estado donde me tiene puesta tu mudanza, la mudanza tan grande que hiziste, que destruyó mi vida y mi speranza;

pues muy bien sabes que no conoziste en mí falta ninguna que hiziese dejarme a mí por esta que escojiste,

ni avrá ninguno que juntas nos viese

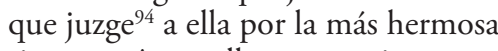
si como tú por ella no estuuiese.

Házeme gran ventaja en vna cosa: en que ella te aborreze y yo te amo, y ansí no quedará de ti quejosa.

Con todas essas cosas yo te llamo; no sé por qué no quieres socorrerme, ni las lágrimas mías que derramo.

Si cierto determinas no quererme,

94. $[s i c]$ 
muy gran bien harás en declararme

tu voluntad, que aquesso es ya valerme.

No quiero más a ti ni a mí enojarme.

Dios te dé con quien amas gran ventura, y a mí de tanto mal quiera librarme, lo qual no espero ni en la sepultura.

TRANSCRIPCIÓN MODERNIZADA Y LUEGO RECONSTRUIDA

Salud, Libea, Meliso envía, si aquél que la suya le destruye aleve, serle otorgada por alguna vía.

¿Por qué permites que así el viento lleve la fe y la palabra que me diste, haciendo tu tornada cierta y breve?

Pasado es el tiempo que me prometiste de ser venido, pero aún no te veo, pues debrías ${ }^{95}$ de venir sino moriste.

Las horas cuento y en ninguna creo, que deba de llegar que pueda verte según lo que en mí hace tu deseo.

Primero llegará la de mi muerte, que la de tu placer pues que te place darme tal galardón por bien quererte.

Si el morir mío a ti te satisface mi ánima irá muy descansada, que viviendo enojarte me desplace.

Acuérdate, Meliso, cuán amada un tiempo fue de ti, que tú decías, «Mi alma sea sola y condenada.».

Y sin ventura y tristes los mis días en este amante amar, Libea, mi bien y mi esperanza y alegría.

Pues, ¿cómo sufriré yo que posea la gloria de este nombre que me dabas otra que ni lo ame ni le crea?

95. Se guarda el deletreo de la época, «debrías», en lugar de «deberías», para mantener el cómputo endecasilábico. 
Acuérdate que en árboles dejabas escrito el nombre mío, que creciendo, mi memoria subías y ensalzabas.

Las nuevas que me da van deshaciendo mi vida y mi salud que tú a Marfira a más y más que a ti no te queriendo.

Y lo peor es que ella suspira por otro amante y a ti te aborrece, mas el que mucho ama poco mira. Pues bien veo yo que no merece ser dejada de ti quien te ama tanto, por más hermosa que esto parece.

Que aunque si me tiene triste llanto toda desfigurada y afligida, no huye quien me mira con espanto.

¿Quién te vido ${ }^{96}$ a ti hacer la despedida que hacías tú de mí? ¿Quién lo pensara según llorada fue y sentida?

De tus lágrimas quienquiera se engañara, y de aquellos suspiros tan ardientes aunque no te quisiera ni te amara.

Cuánto más yo, que miedo de parientes. ni de honra, ni de vida, ni del cielo, me hizo recelar inconvenientes.

¿Dónde están las promesas y el consuelo que me dabas a mí cuando te ibas, asegurando siempre mi recelo,

"Libea», diciendo, "cata que me escribas, escríbeme si quieres, que no muera.», lágrimas de tus ojos derramando vivas?

Fácil te fue engañar a quien creyera, sólo en decillo tú, que no había estrella en el cielo que sol ni lumbre diera.

Holgaste de engañar una doncella de quien ya señor eras verdadero,

96. Se guarda el deletreo original de «vido» en lugar de «vio» para mantener el cómputo endecasilábico del verso. 
que alguna hora te dio descanso vella.

¿Cuál dios permite, pues yo por ti muero, que no te duelas de un dolor tamaño? Mas si hay justicia en el cielo, espero

que habré venganza deste mal extraño, tan grande y cruda, que te habré mancilla, aunque no la merece ya tu engańo. Mi pena es tanta, que pensar decilla es imposible aunque ésta sea larga, que ni puedo contalla ni escribilla;

que esta miserable vida amarga, cuyos despojos te harán contento, saldrá muy presto desta dura carga.

No quiero más palabras dar al viento, y pues las que me diste se ha llevado, llevarse ha con ellas mi tormento;

y este tan crudo amor mal empleado, principal causa fue de mi mal andanza y deste tan bajo y $\tan$ triste estado

donde me tiene puesta tu mudanza, la mudanza tan grande que hiciste, que destruyó mi vida y mi speranza;

pues muy bien sabes que no conociste en mí falta ninguna que hiciese dejarme a mí por esta que escogiste,

ni habrá ninguno que juntas nos viese que juzgue a ella por la más hermosa si como tú por ella no estuviese.

Háceme gran ventaja en una cosa: en que ella te aborrece y yo te amo, y ansí no quedará de ti quejosa.

Con todas esas cosas yo te llamo; no sé por qué no quieres socorrerme, ni las lágrimas mías que derramo.

Si cierto determinas no quererme, muy gran bien harás en declararme tu voluntad, que aqueso es ya valerme. 
No quiero más a ti ni a mí enojarme.

Dios te dé con quien amas gran ventura, y a mí de tanto mal quiera librarme, lo qual no espero ni en la sepultura.

[15r][XXVII] [Anón.; Quintilla]

dama de lindo valor

medecina del herido

de las hermosas la flor

hoyd mi grande damor

derramese en su sentido

[XXVIII] [Anón.; Quintilla]

Respuesta de la dama

Soy ynportuno señor

muy sin tiento y desmedido

con vuestra[s] quexas de amor

tened que hos doy con primor

tanto quanto aueys podido

Testimonios: UAM, 2977a, Ms. 4128, 15-16, «Dama de gentil mirar», Juan Linares, recopilación del Cancionero llamado Flor DE ENAMORAdos, s. XVIIIXIX. Cancionero llamado Flor De enamorados (Barcelona 1562), ed. Rodríguez-Moñino y Devoto, (1954), 45-46; Pregunta de vn galan a vna señora la qual hallaran si la saben buscar en la misma copla. Dama de lindo valor / medecina del herido / de las hermosas la flor / hoyd mi graue clamor, / derramese en su sentido; Respuesta de la dama, en la qual hallaran lo que le responde por el mismo artificio y consonancias que arriba. Soys importunado señor / muy sin tiento y desmedido / con vuestras quexas de amor / tened que os doy con primor / tanto quanto haueys pedido. Cf. las quintillas III, de DDHdM (2007), 383, con las que comparte ciertas afinidades de expresividad.

\{En una columna a la derecha de estas quintillas se lee lo siguiente:\}

dama de llindo [sic] / me / de / ho / der / soy / muy / con / tenta / do / ma patri \& filio

TRANSCRIPCIÓN MODERNIZADA

27. «Dama de lindo valor, medicina del herido, de las hermosas la flor, oíd mi grave clamor, derrámese en su sentido.»

28.

«Soy importuno, señor, muy sin tiento y desmedido con vuestras quejas de amor; tanto cuanto habéis pedido.» 


\section{Índice de primeros versos}

(XV) Agora en la dulçe sçiençia enbraveçido (Ahora en la dulce ciencia embravecido)

(IV) Alla en la gran babilonja (Allá en la gran Babilonia)

(XXII) quan mal parece al mundo vn movimj[ento] (Cuán mal parece al mundo un movimiento)

(XI) Quando sera aquel dia uenturoso (¿Cuándo será aquel día venturoso) (XXVII) dama de lindo valor (Dama de lindo valor)

(III) durmiendo estaua faraon (Durmiendo estaba Faraón)

(XII) En la fuente mas clara y apartada (En la fuente más clara y apartada)

(XVIII) En vn rrustico uestir y gran baxesa (En un rústico vestir y gran bajeza)

(XXV) Estando naturaleza deseosa

(V) Estoi contino en lagrimas bañado (Estoy contino en lágrimas bañado)

(XIII) Basto la vida en males y amor creçe (Gasto la vida en males y amor crece)

(XXIV) hero con amorosas lagrimas lloraba (Hero, con amorosas lágrimas lloraba)

(XXIII) Ero de vna fatiga congoxosa (Hero, de una fatiga congojosa)

(VIII) hero que ningun dia rresposaua (Hero, que ningún día reposaba)

(II) Josep niño y pequeño (Josef, niño y pequeño)

(IX) la gran absençia a ero le cabsaua (La gran ausencia a Hero le causaba)

(VI) leandro que de amor en fuego ardia (Leandro, que de amor en fuego ardía)

(VIII) leandro que en amores no se halla (Leandro, que en amores no se halla)

(XIX) Los ojos no pecaron en miraros (Los ojos no pecaron en miraros)

(XXI) mjs ojos de llorar estan cansados (Mis ojos de llorar están cansados)

(XX) O yngrato amor quien no te conoçiese $\left({ }_{i} \mathrm{O}\right.$ ingrato amor! $¡$ Quien no te conociese!)

(I) Perseguido anda David

(XVII) Pinzel diuino uenturosa mano (Pincel divino, venturosa mano)

(X) Quien de cristal el coraçon tuviera (iQuien de cristal el corazón tuviera)

(XXVI) Salud libea meliso enbia (Salud, Libea, Meliso envía)

(XVI) Si pudiese bastar el bien amaros (Si pudiese bastar el bien amaros)

(XXVIII) Soy ynportuno s[eñ]or (Soy importuno, señor)

(XIV) buelue el çielo y el tienpo huye y calla (Vuelve el cielo y el tiempo huye y calla) 


\section{Apéndice I}

Reproducción facsímil del manuscrito

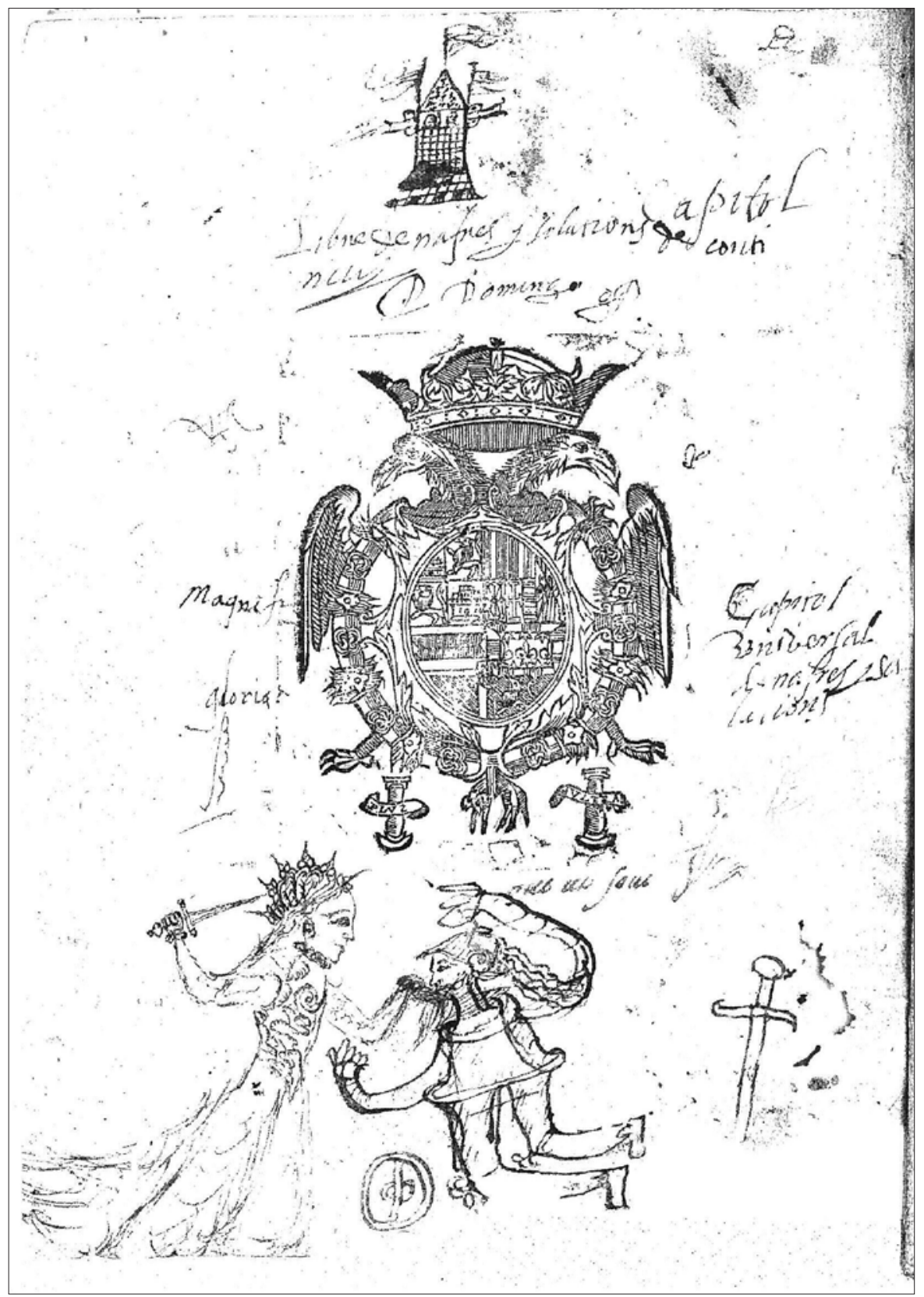




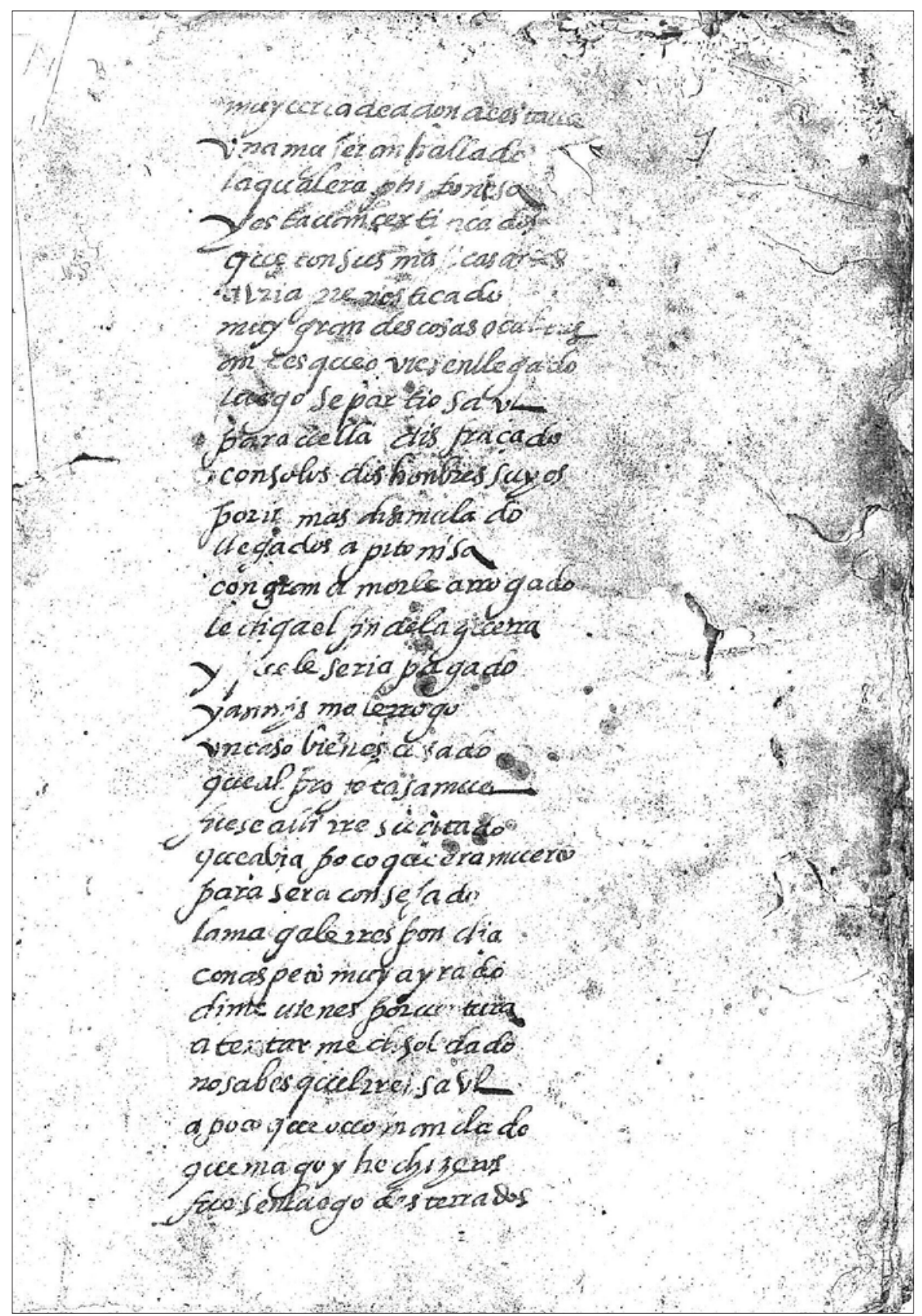


Sout comilifizamentos

abiend a asequito - ama.j ja shitis fecha sog ecreosico menca do

Yei jeofetasamucL

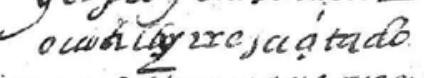

Drostienengue zuecipro zta ofics ó pirin claña do

Yuabido quesa we exa eigluekobrakabias. laima qa con qrom miedo

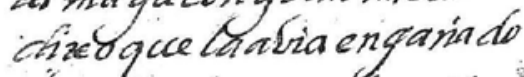
dixolitreiqueno tomise

Yicconcase de grads. todologueatia vis bo

- Tlamegalea contado

Senoyjuaco vnus hoses en hermoguzadoíatos quedela trezra an sultide yud el kapreg unton do que jorma to mad maion cuiviquecelos sia mivado eild chxo csya may crigo actier to de onniou pano cóno ciondo asantace sacelentrizra jesedado ycaydo e nella dey no for asa mecel aca dorke do 


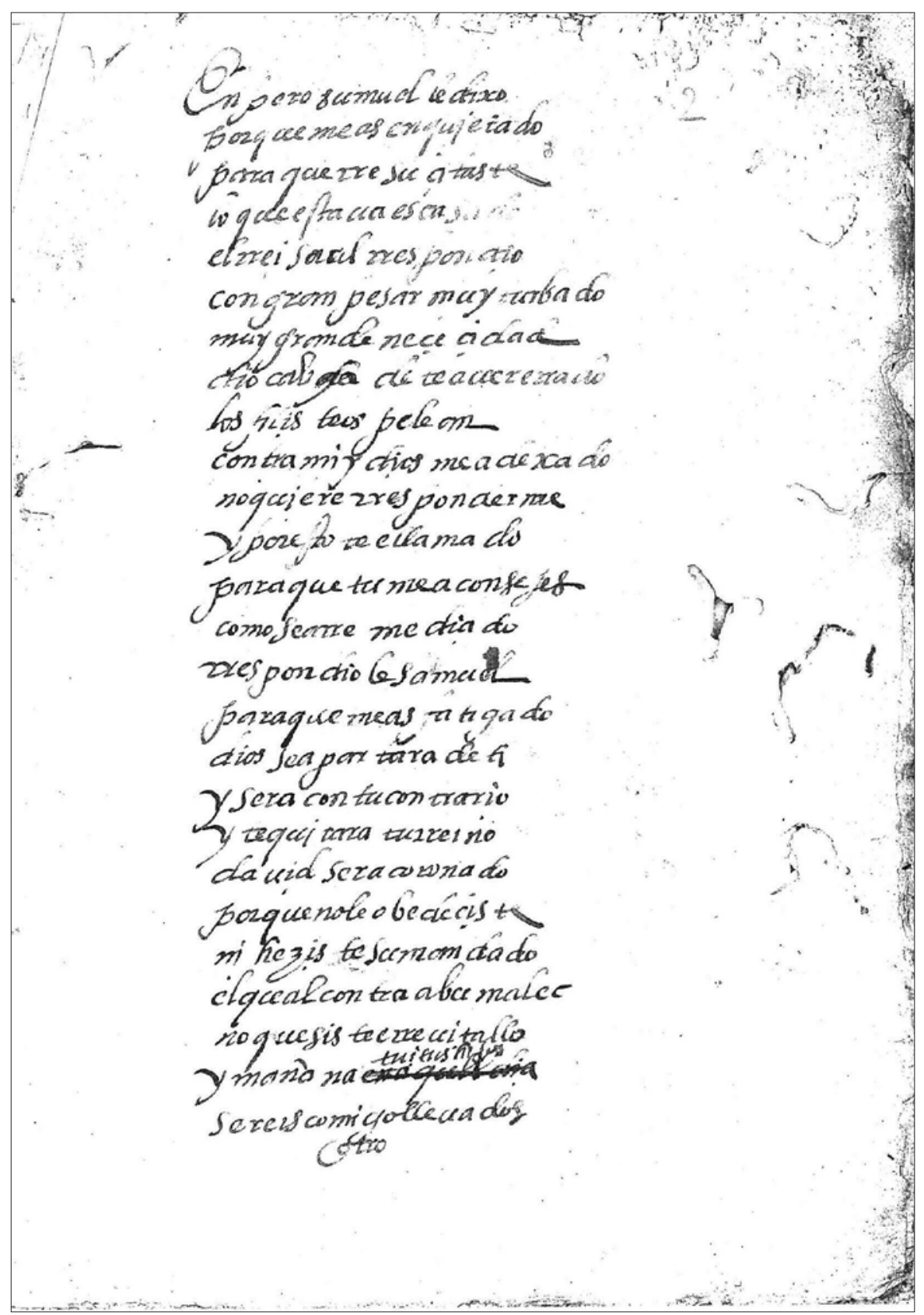




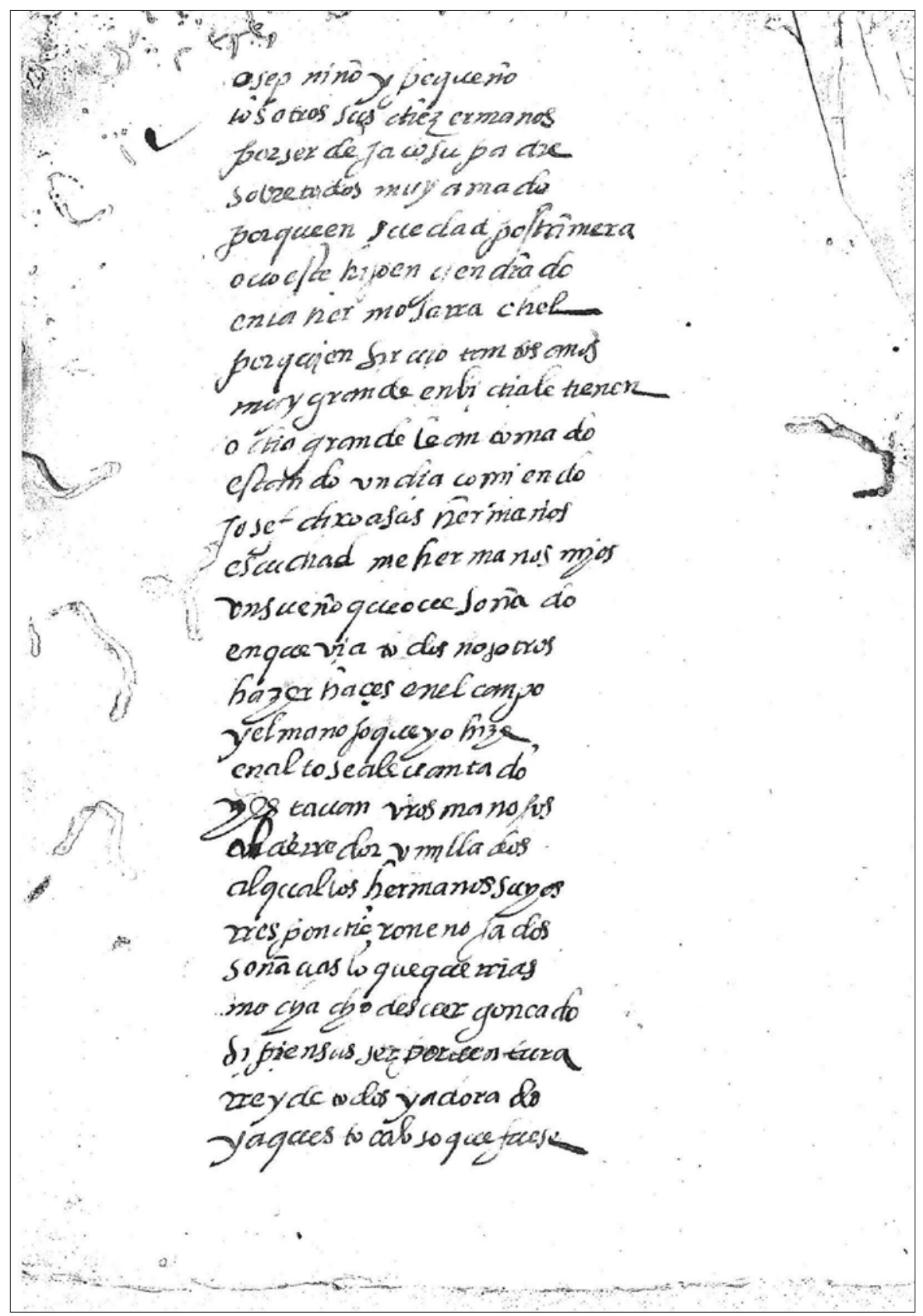




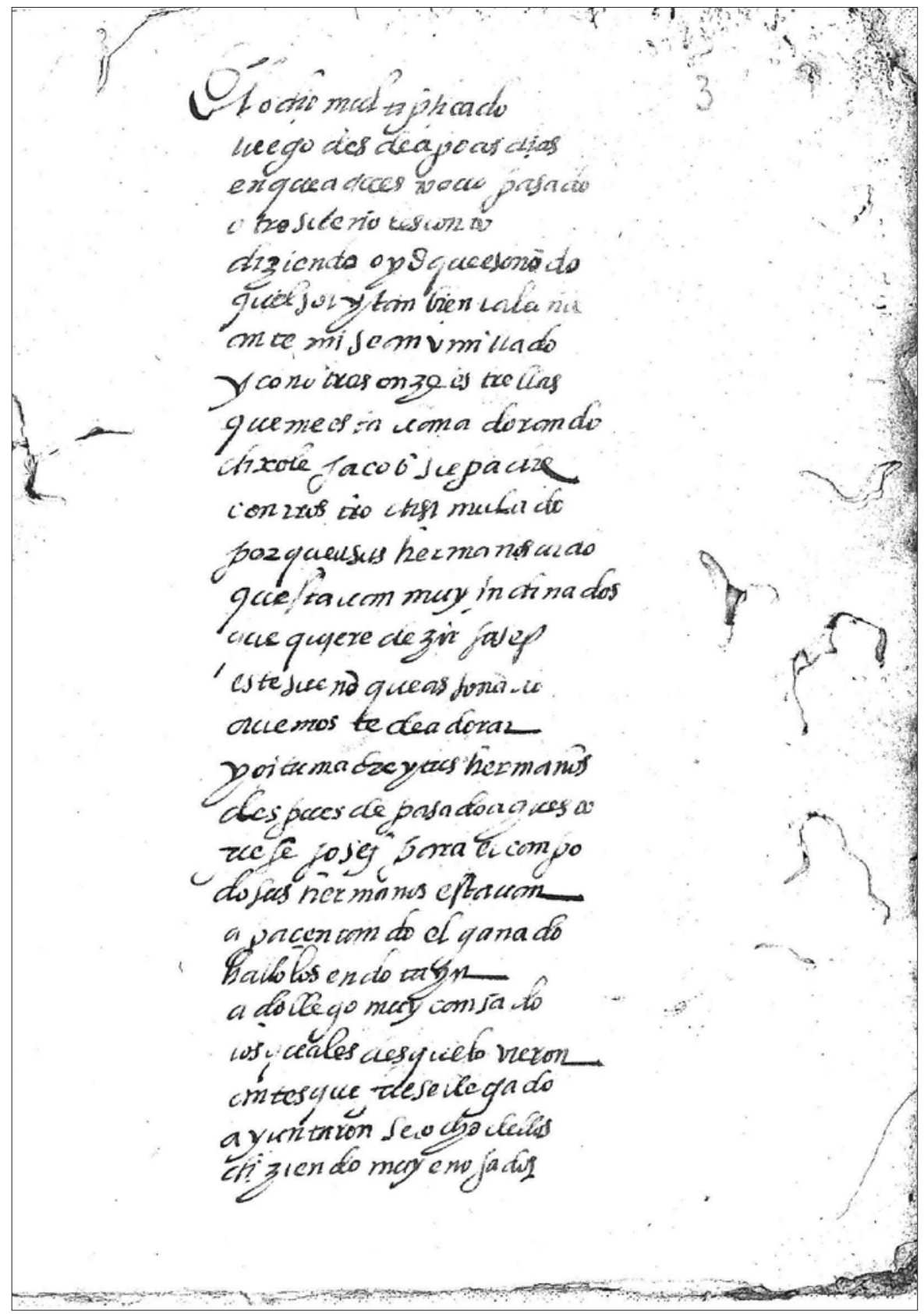




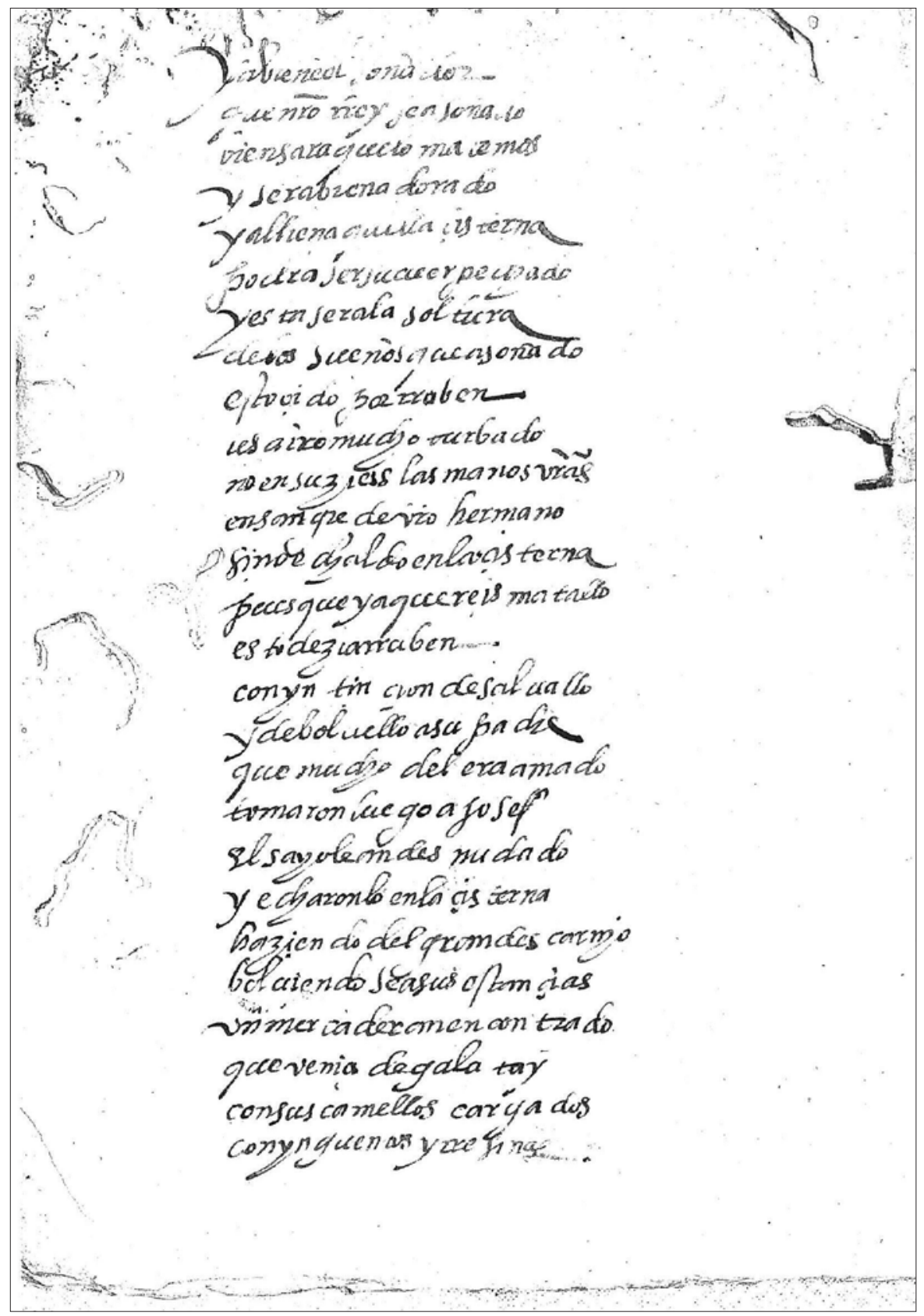




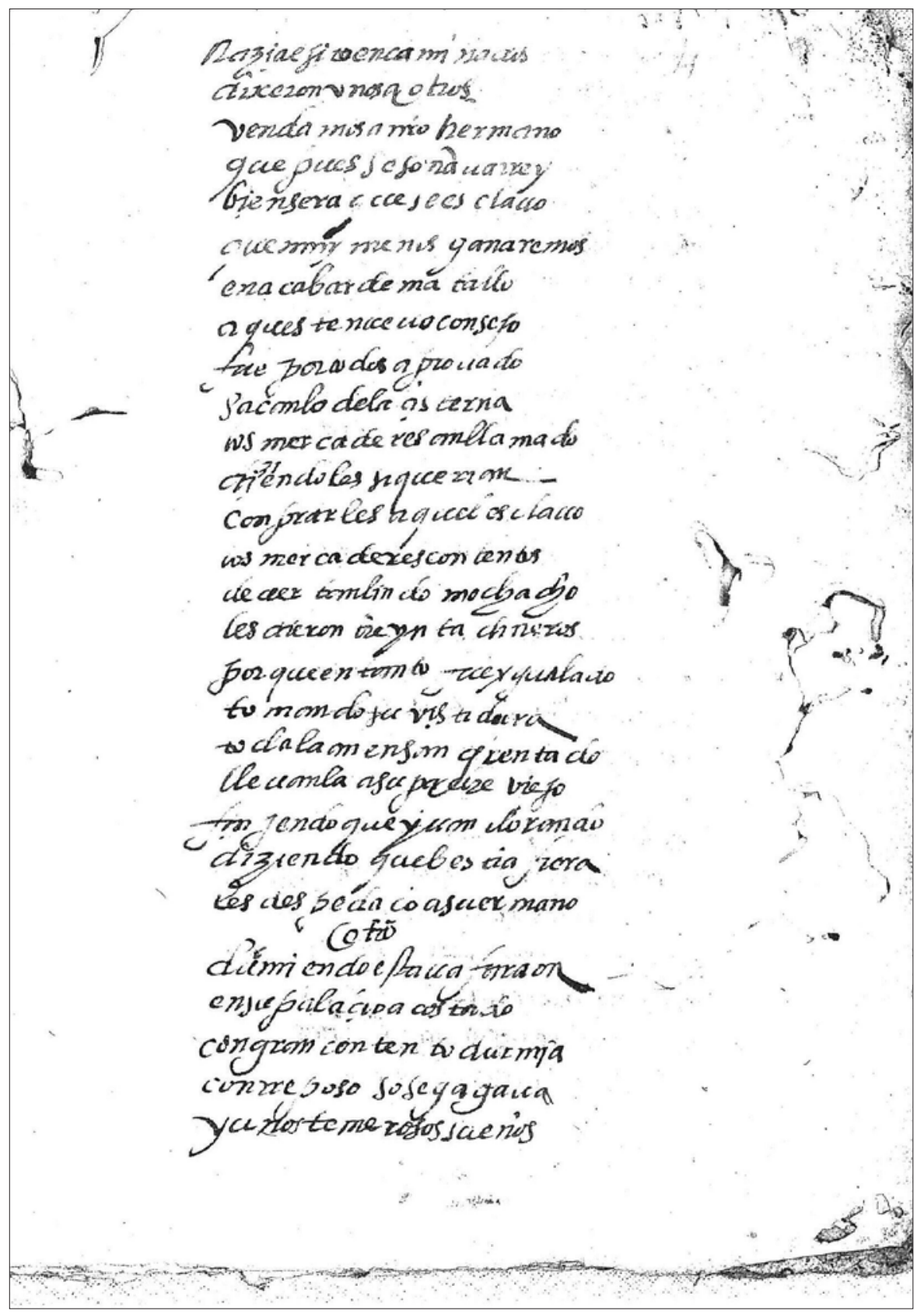




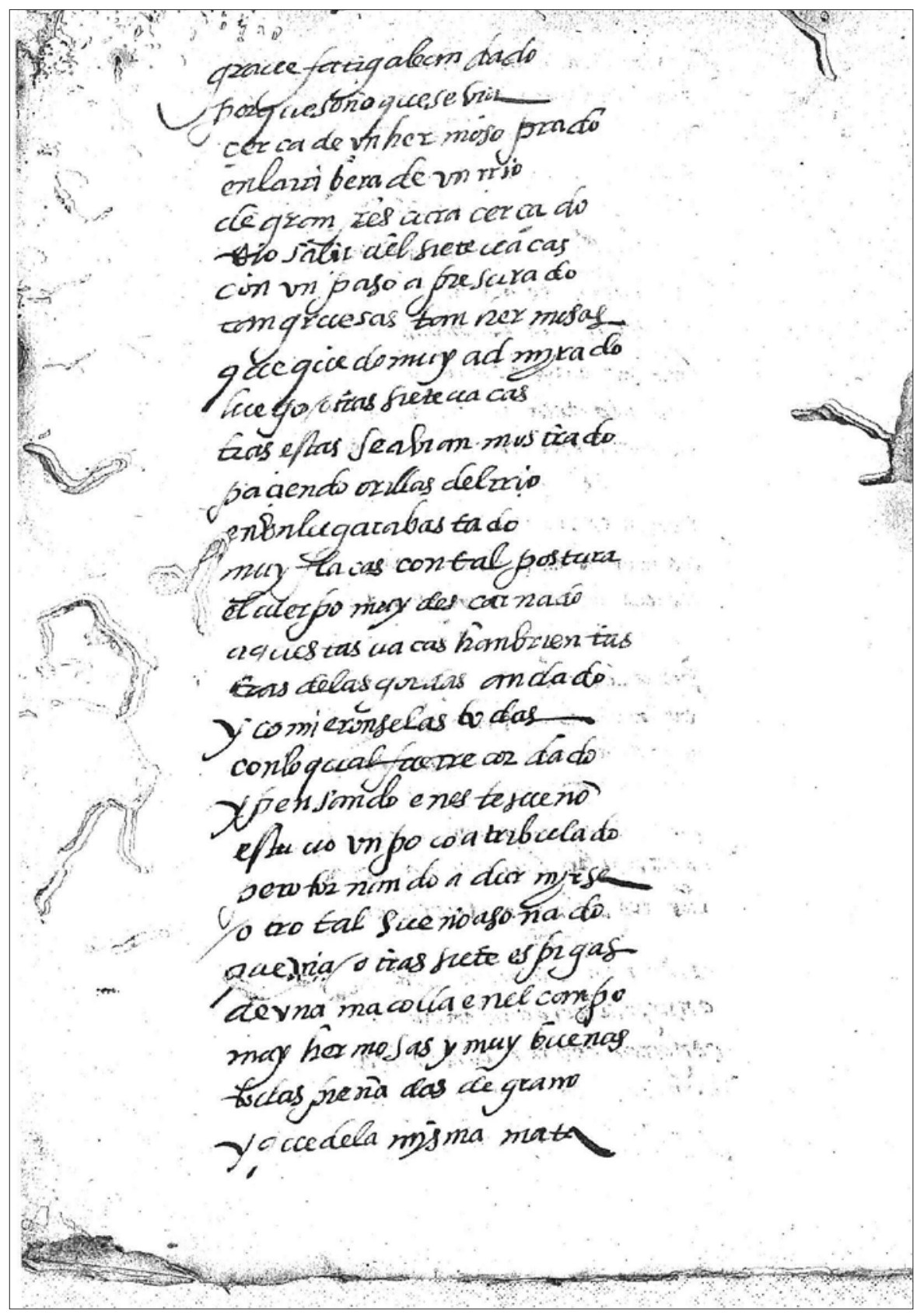




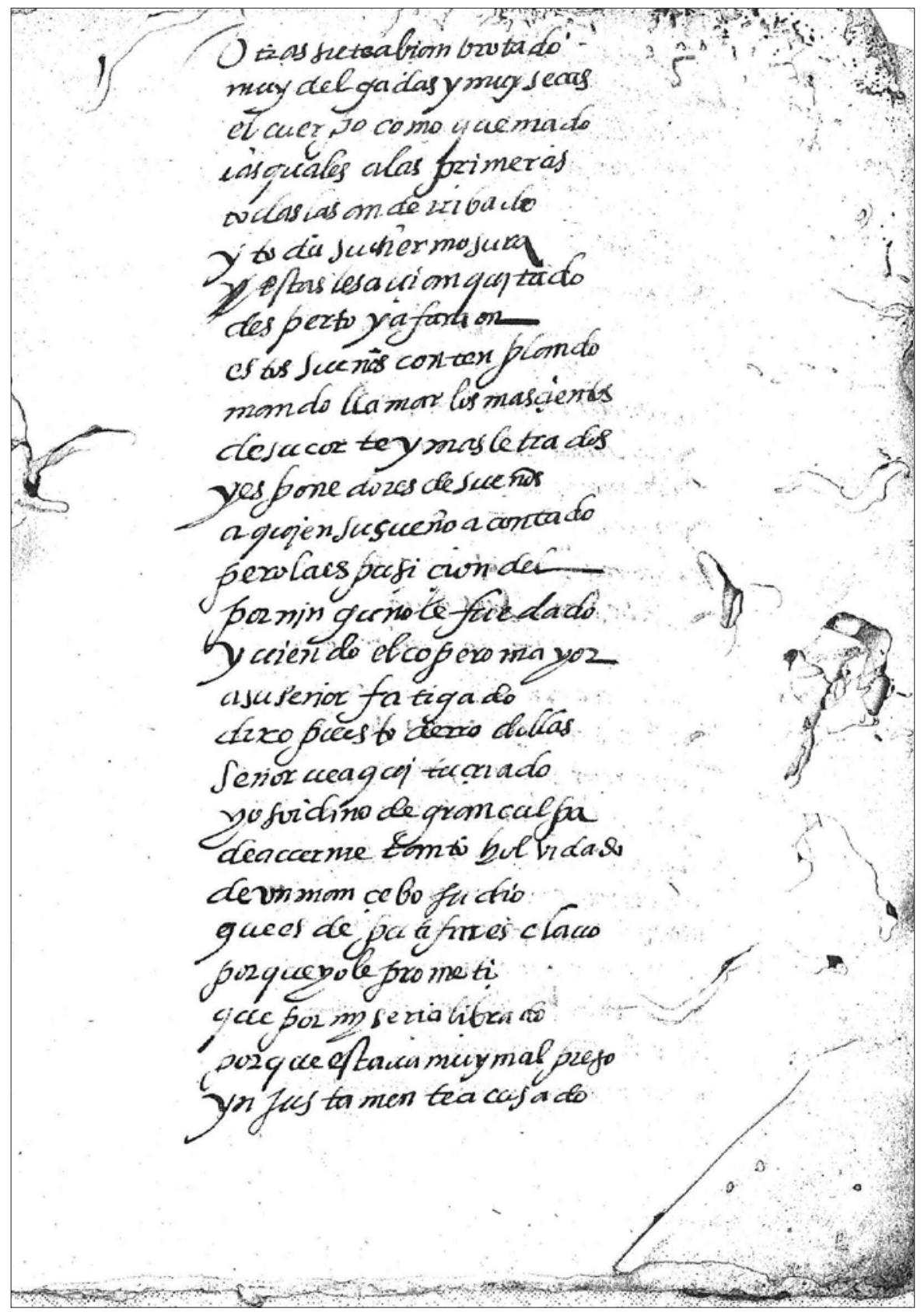




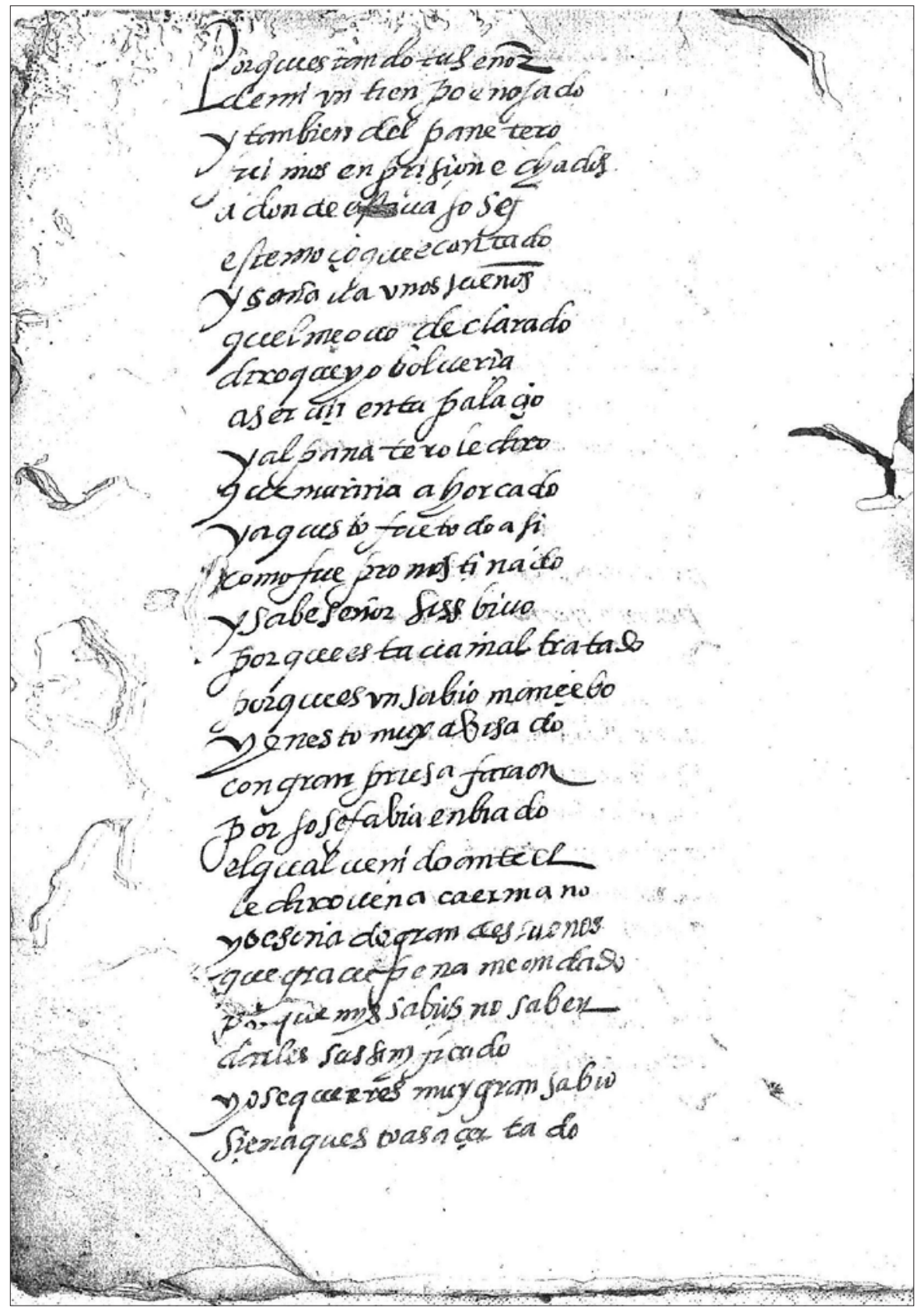




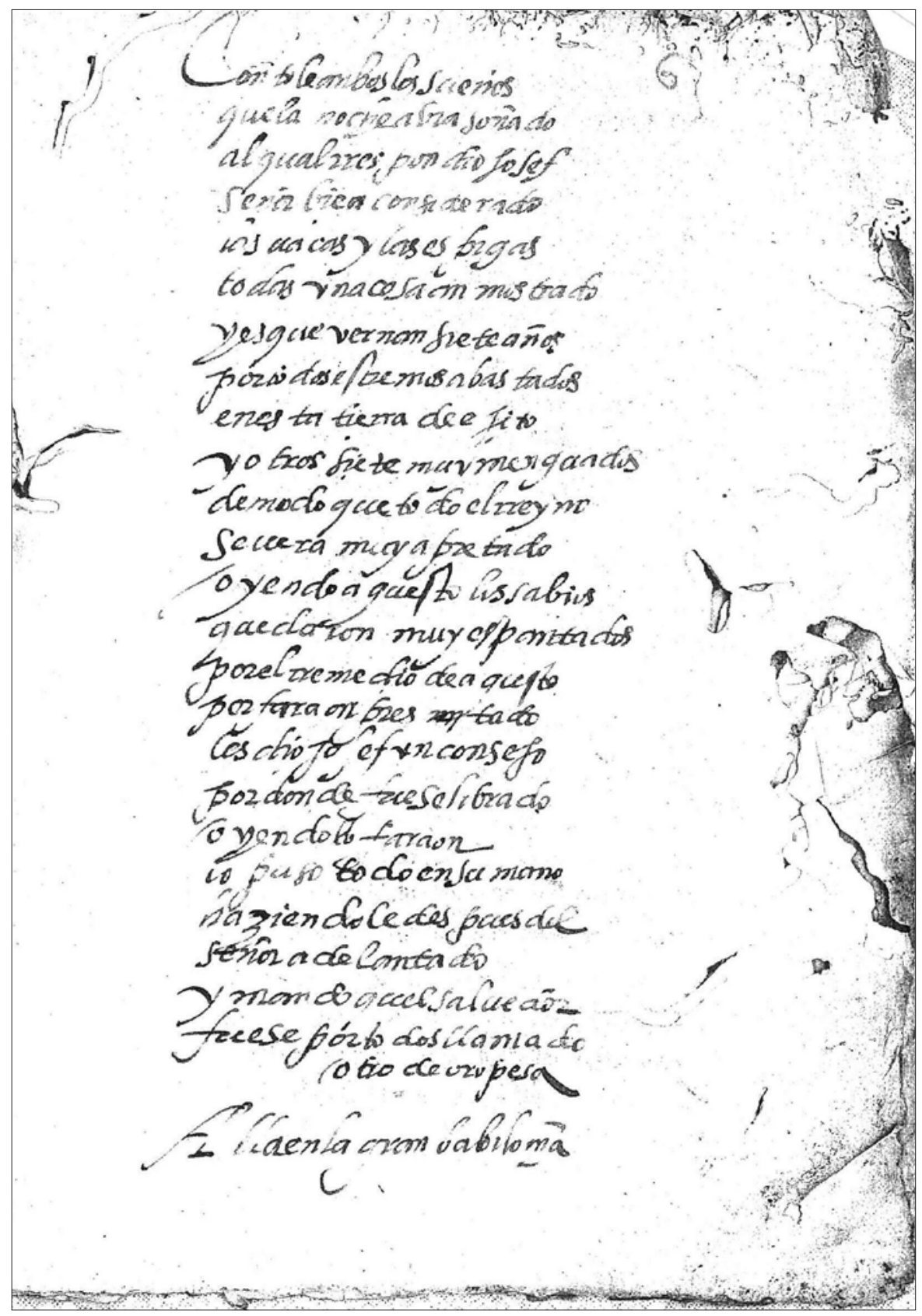




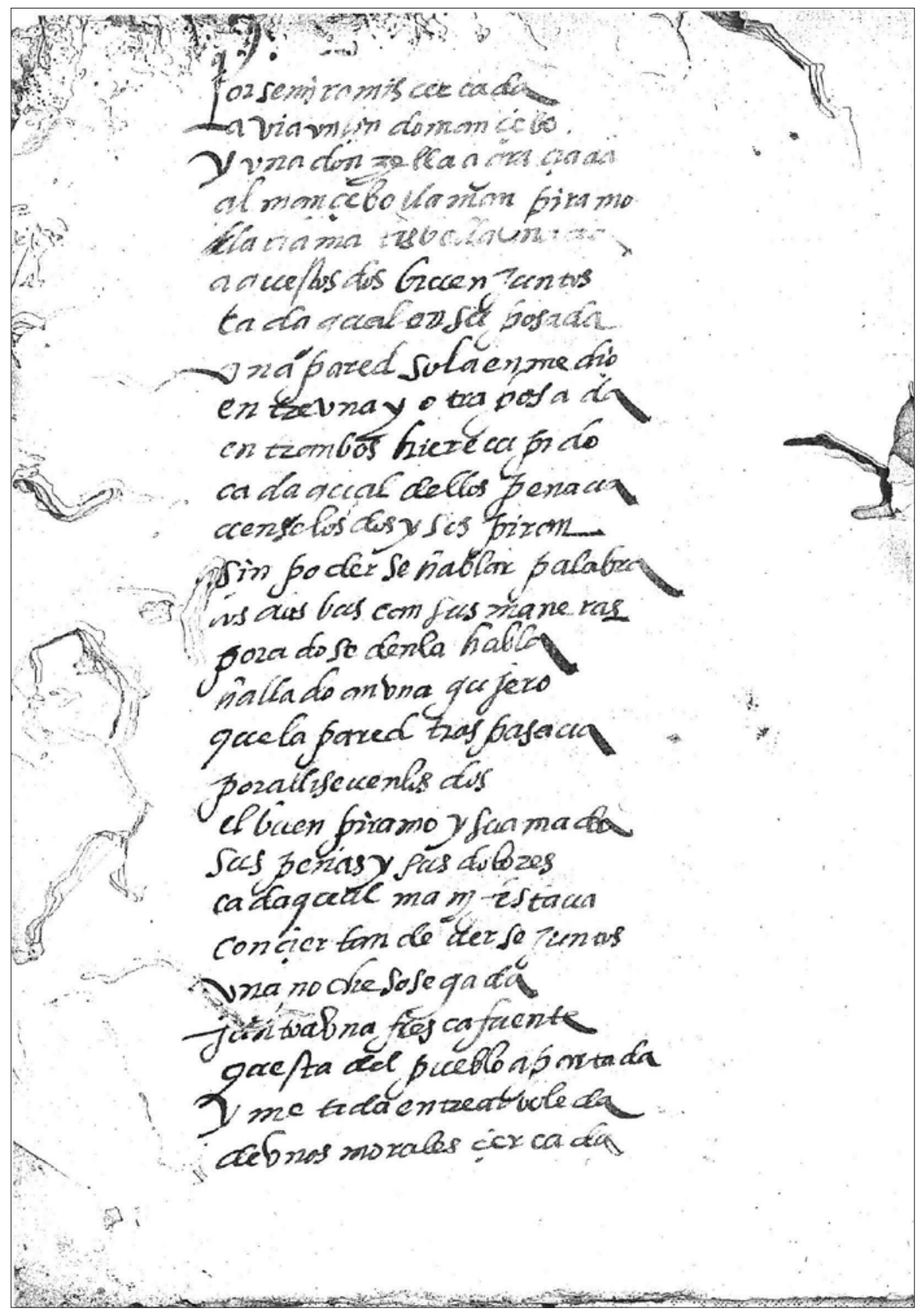




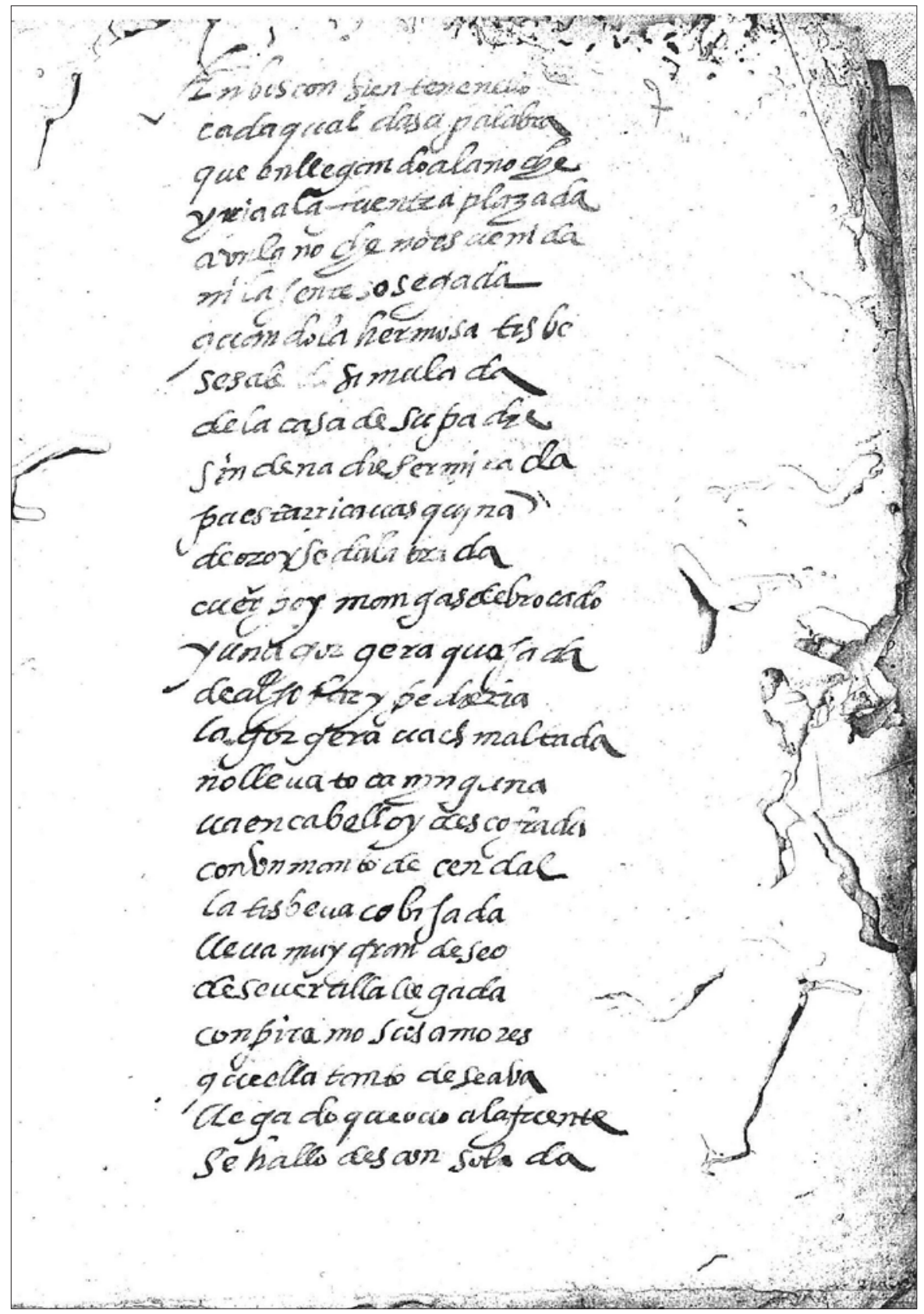




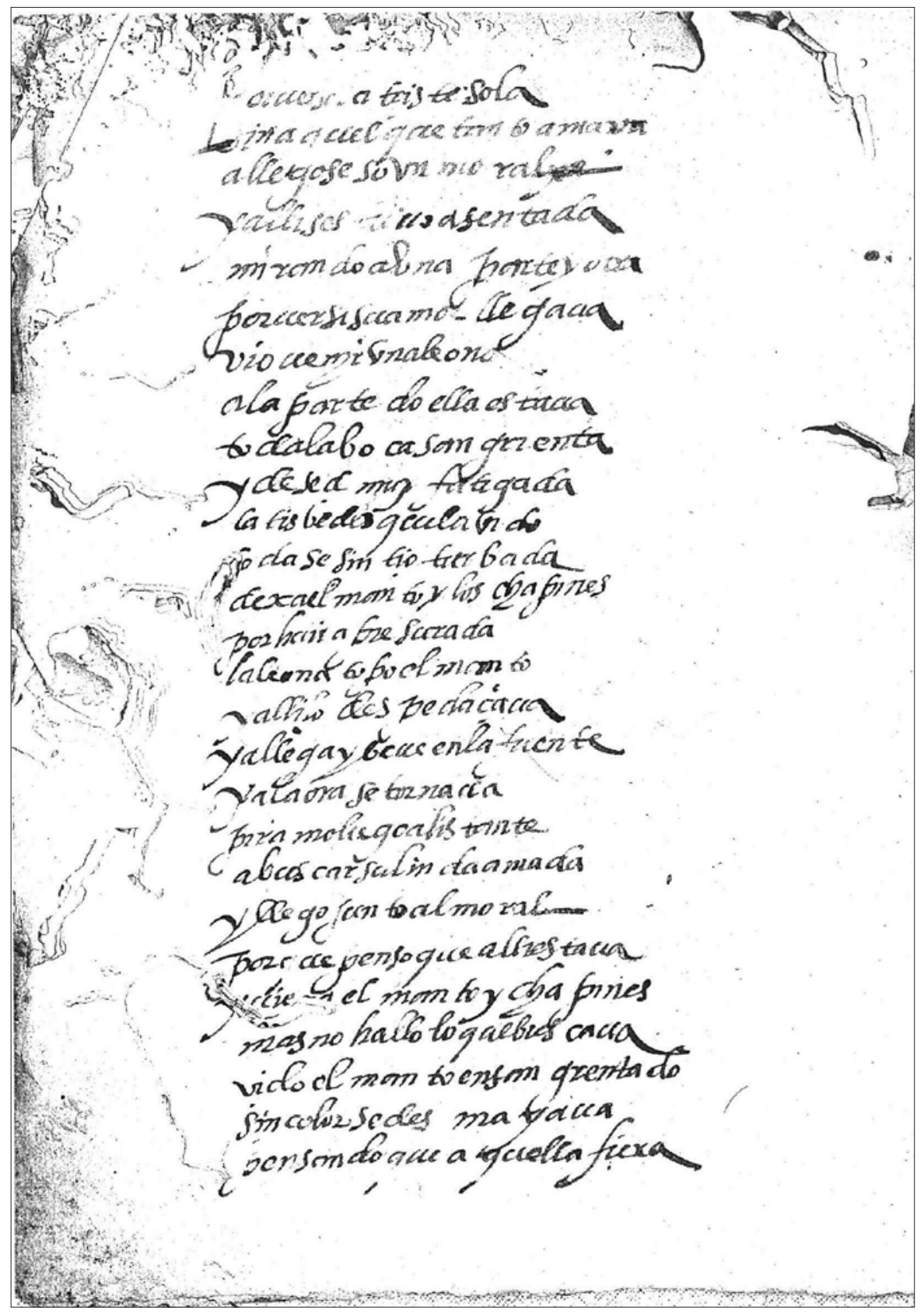




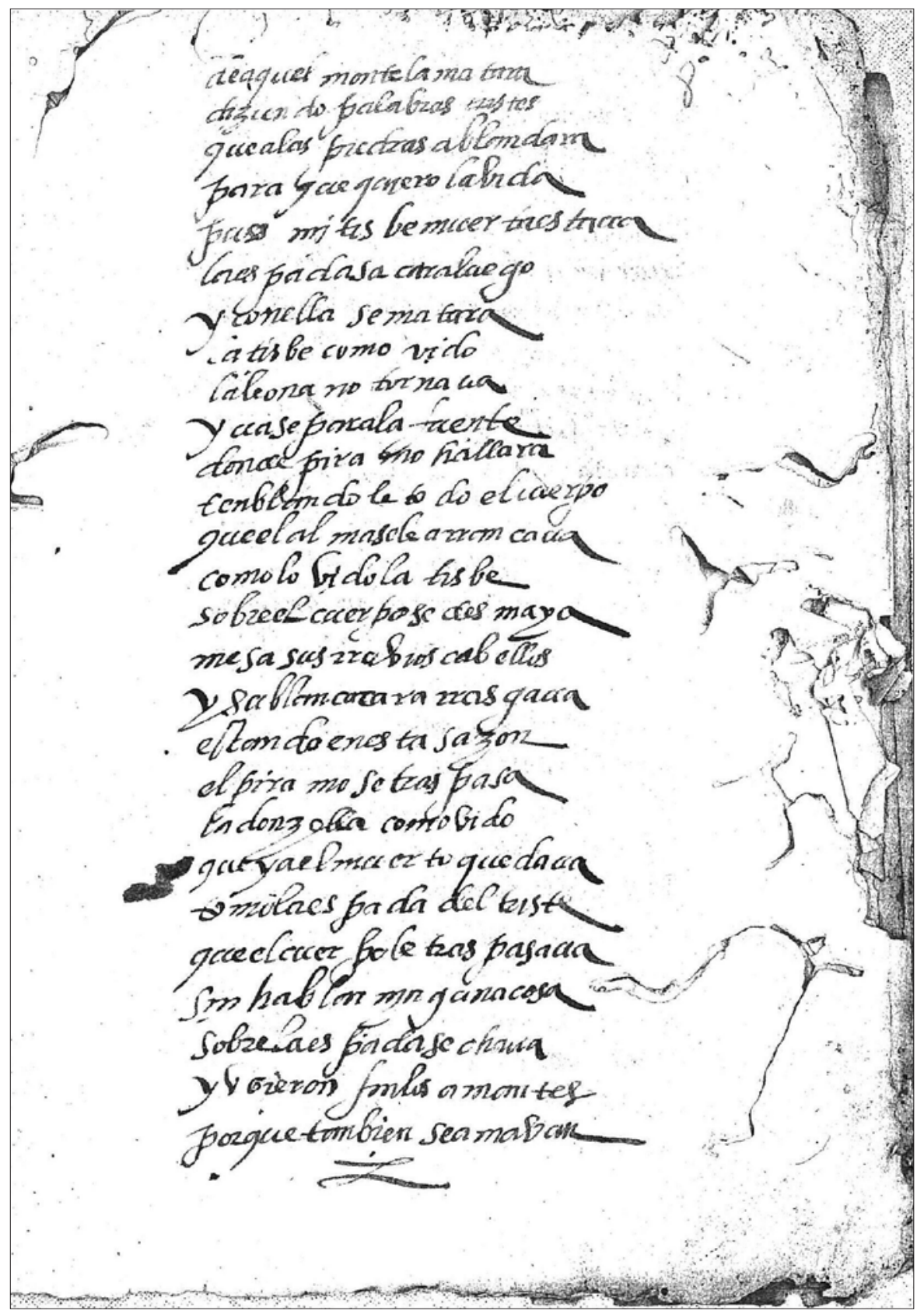




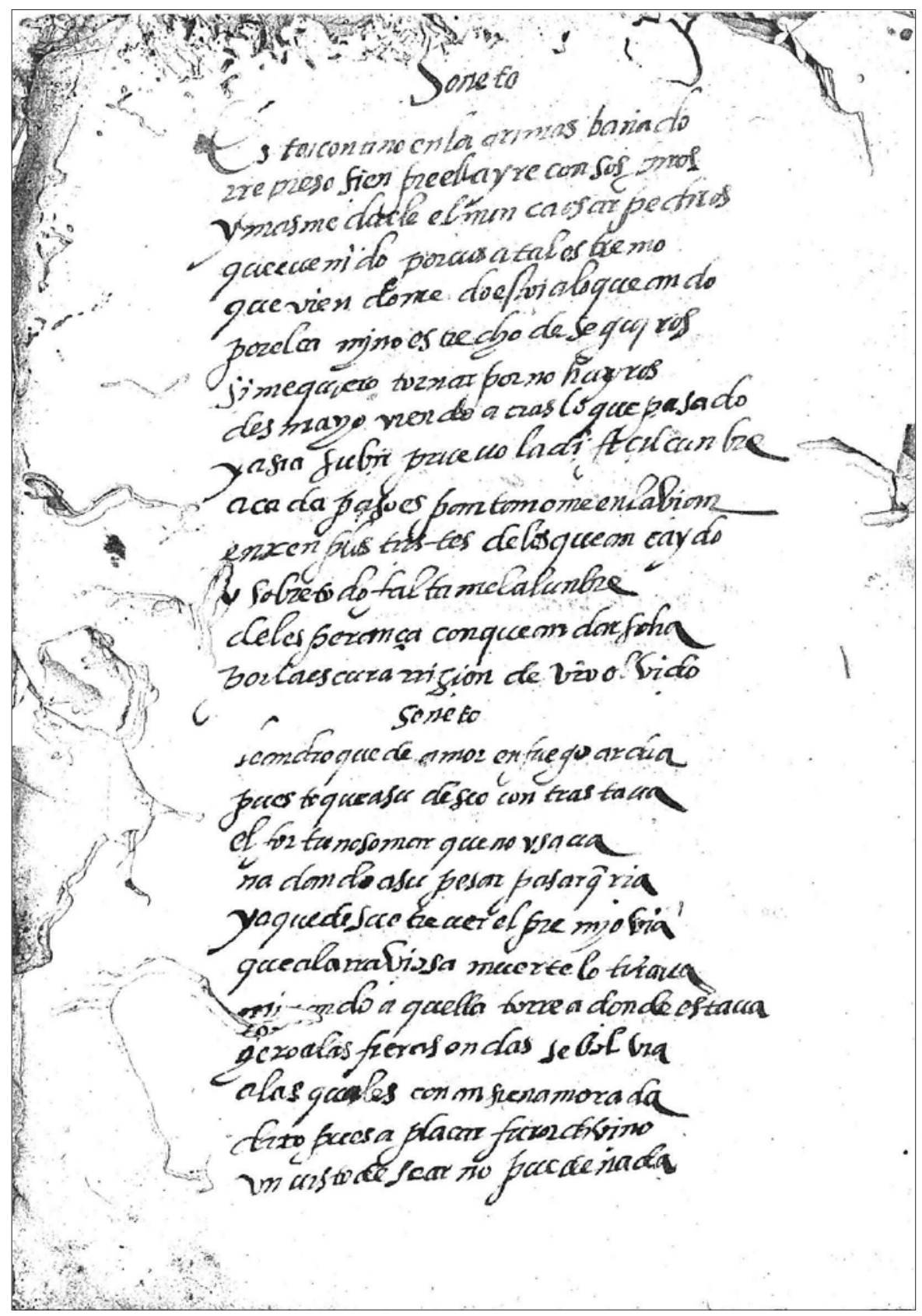




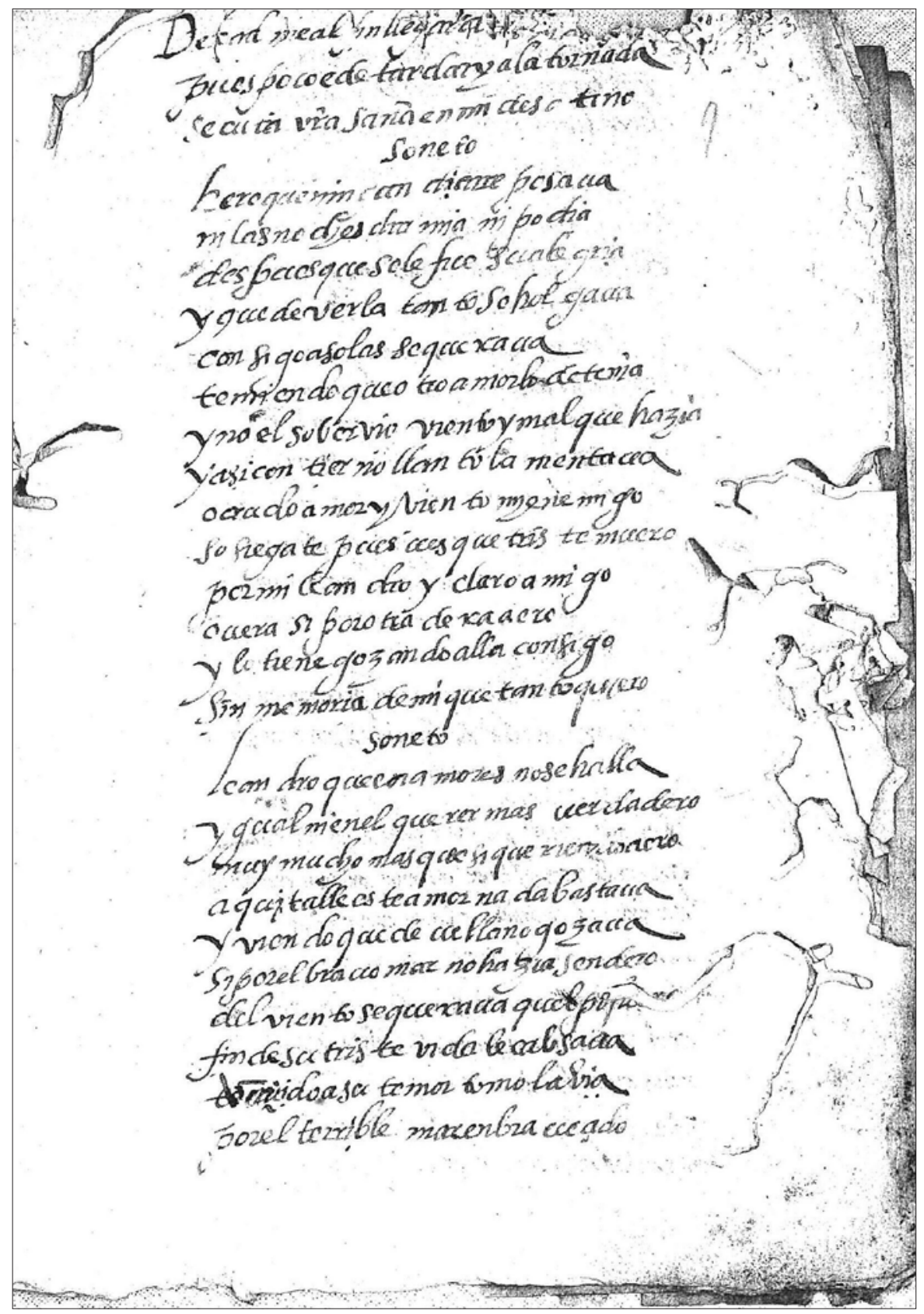




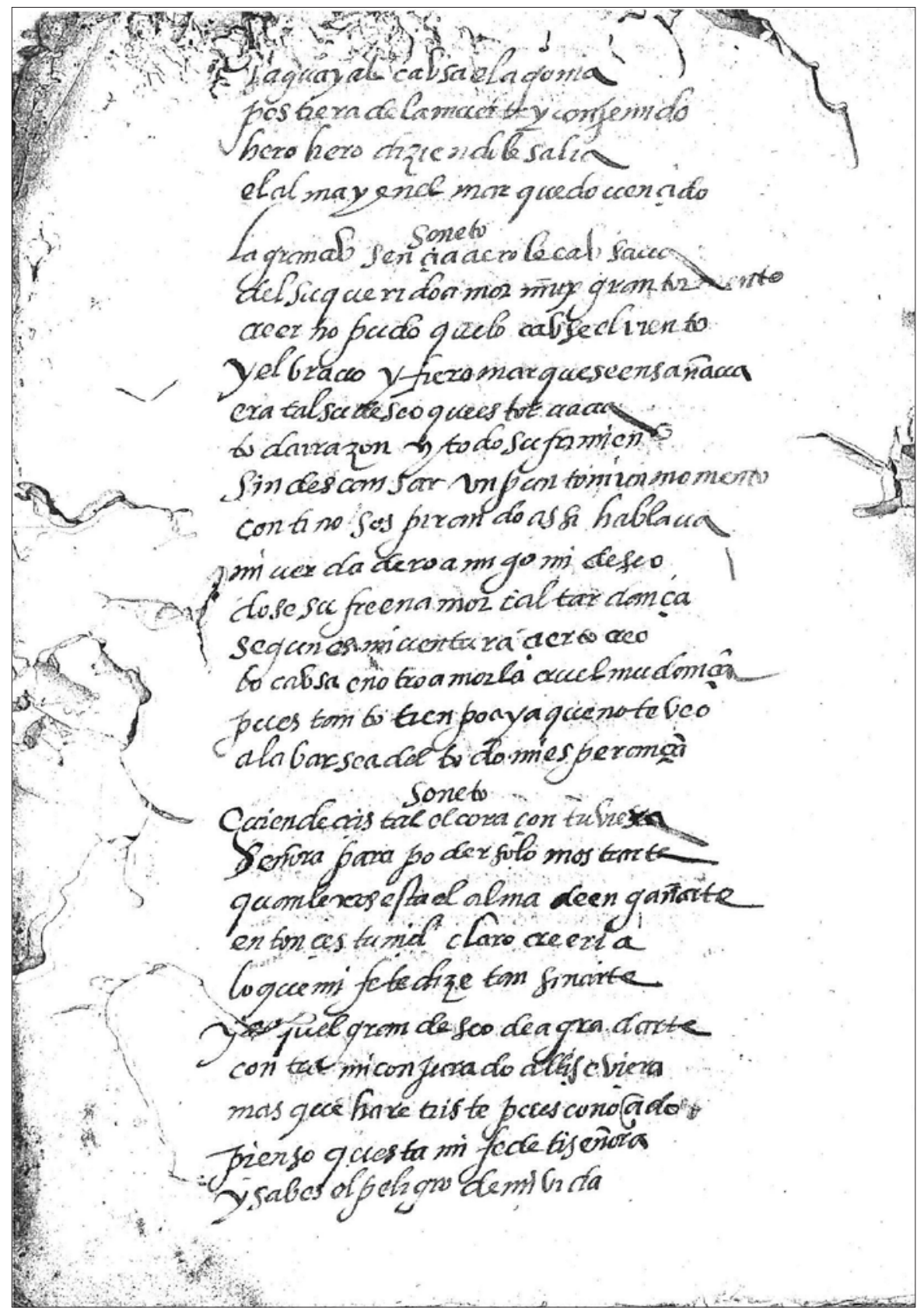




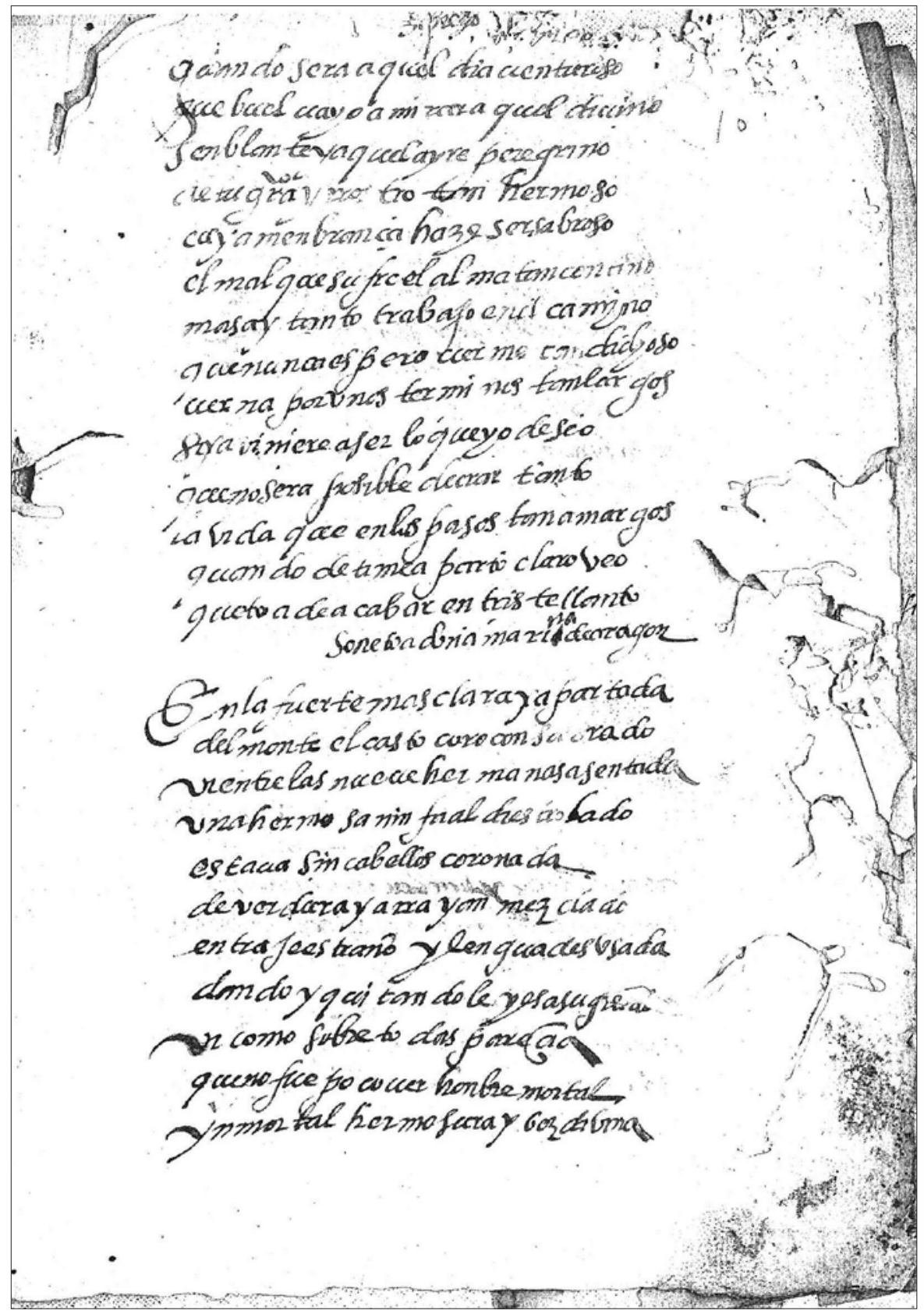




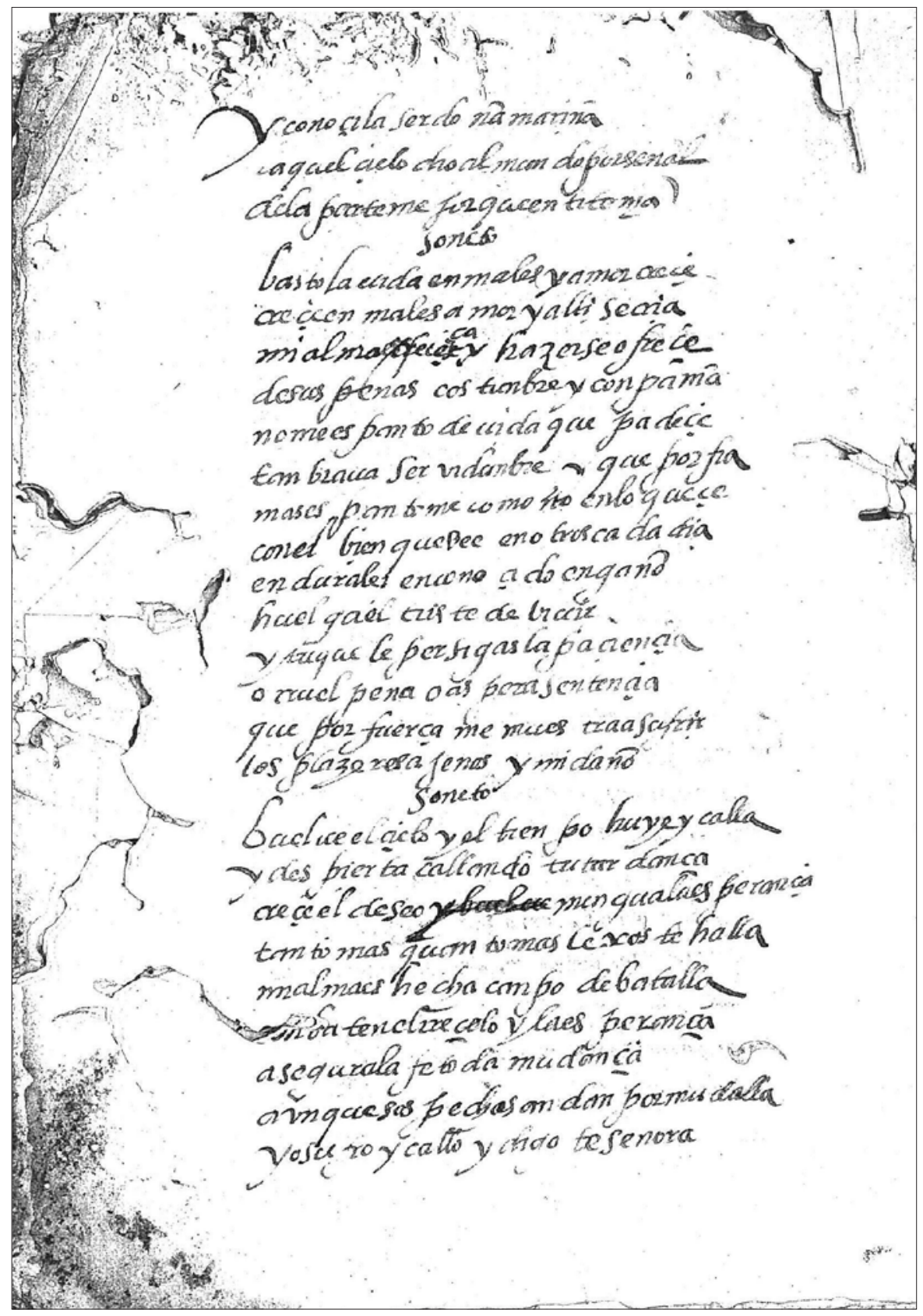




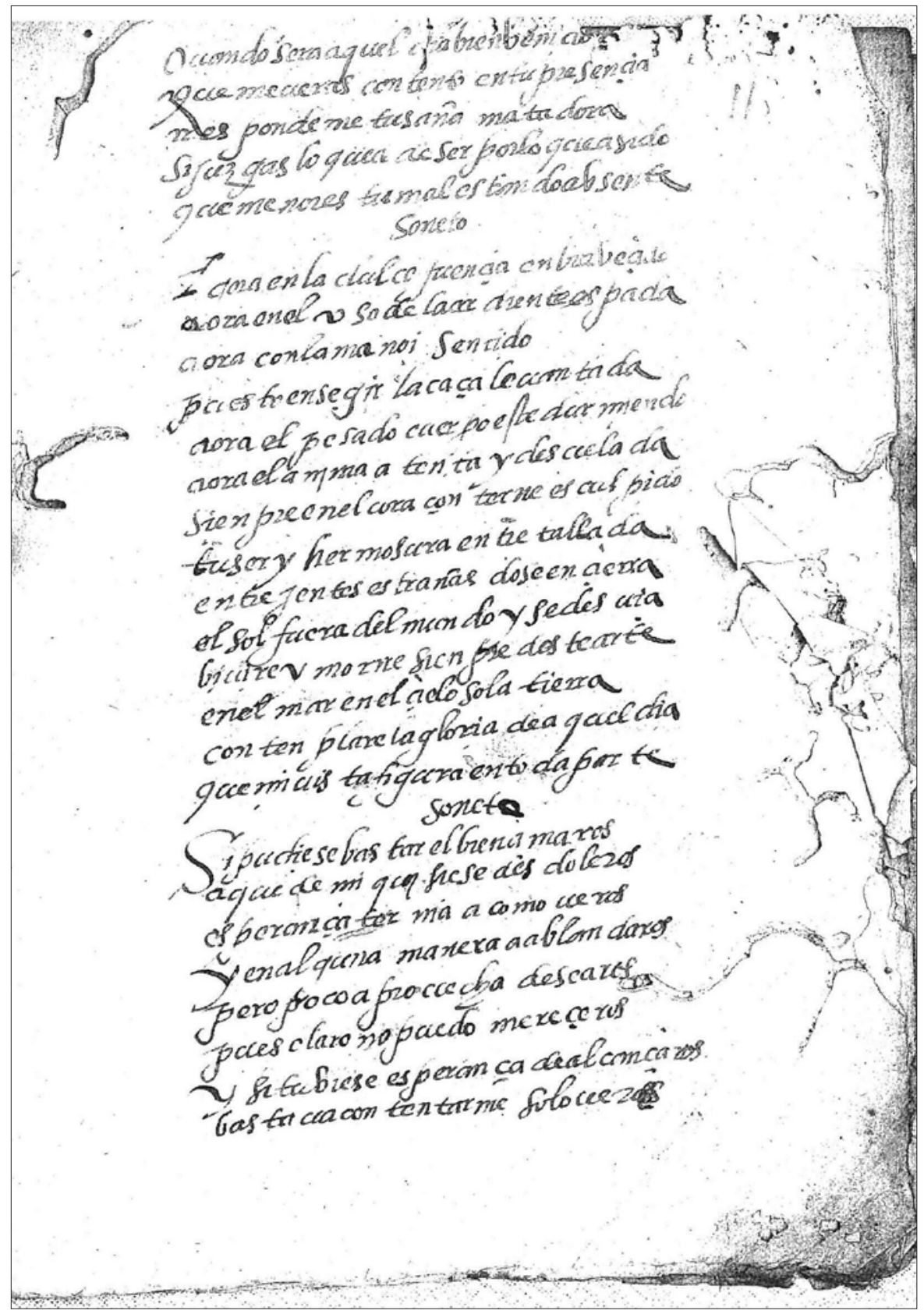




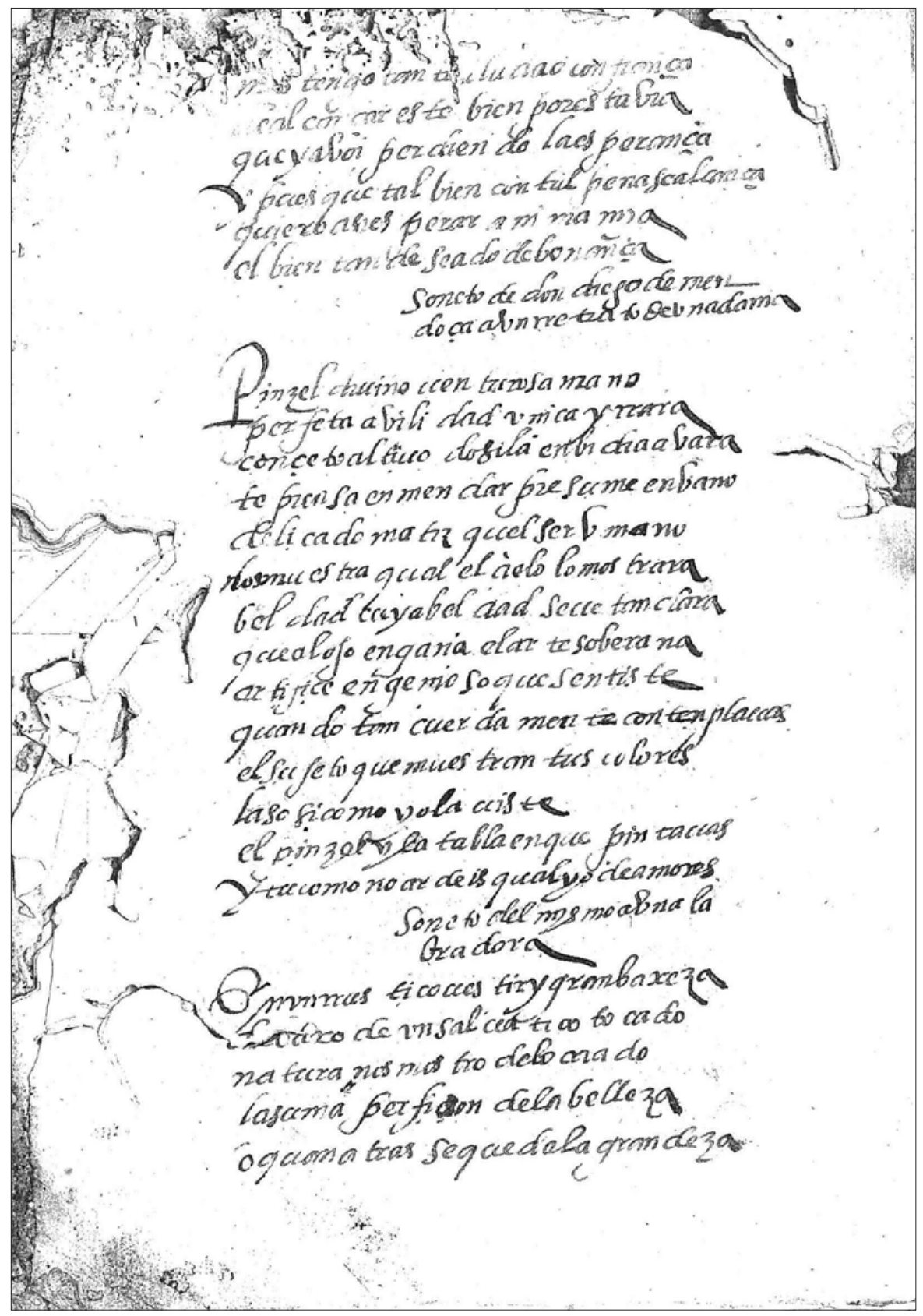




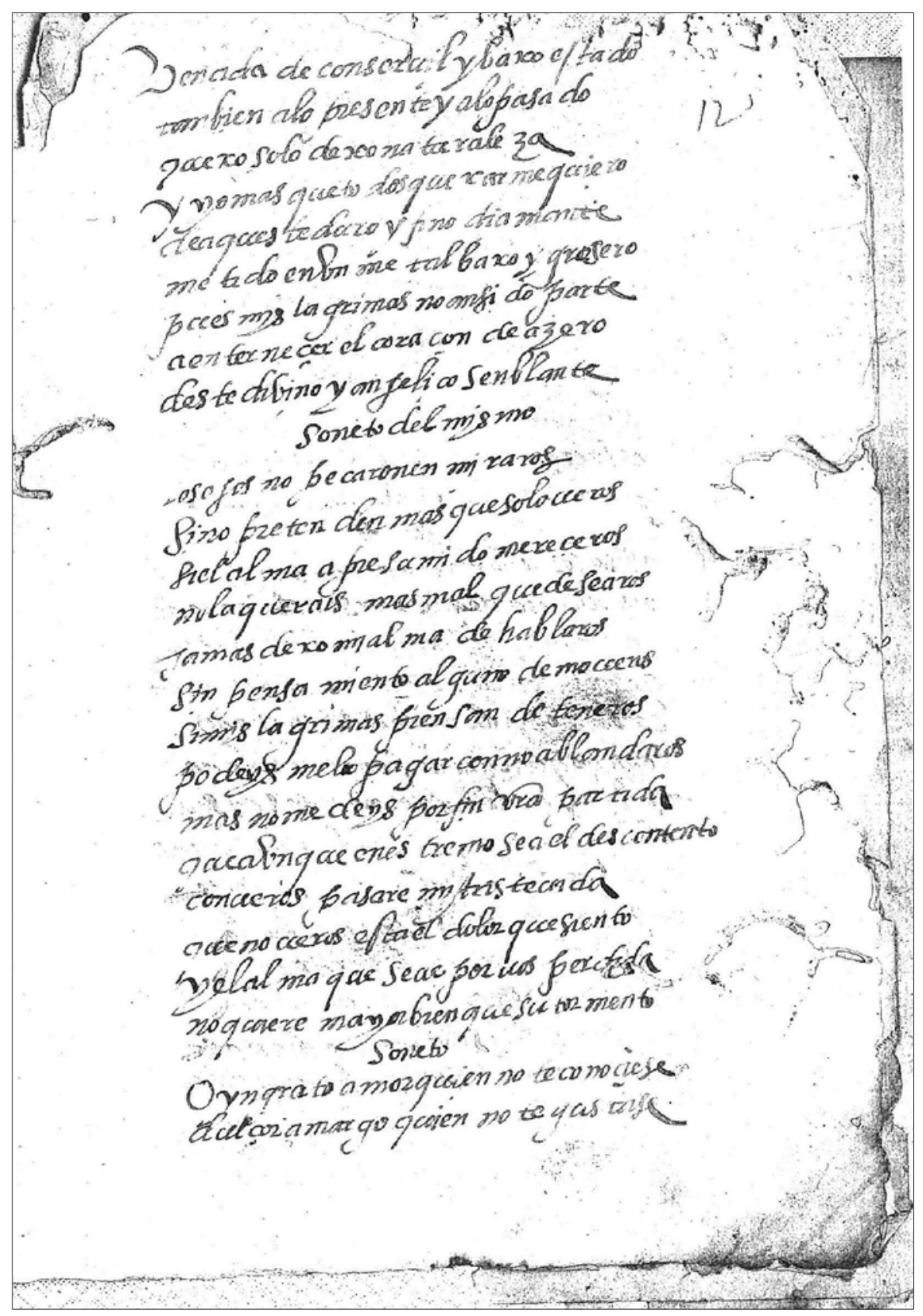




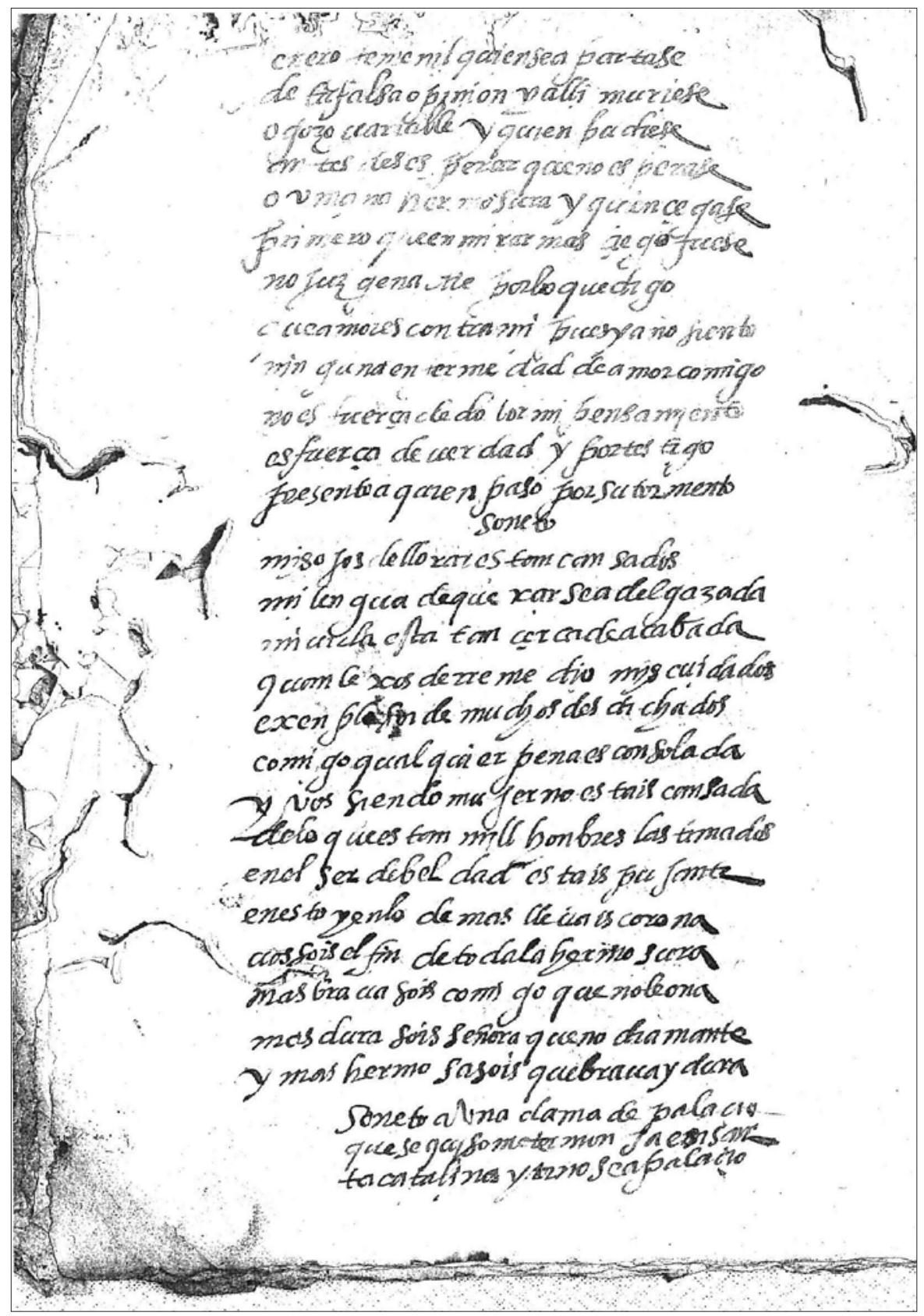




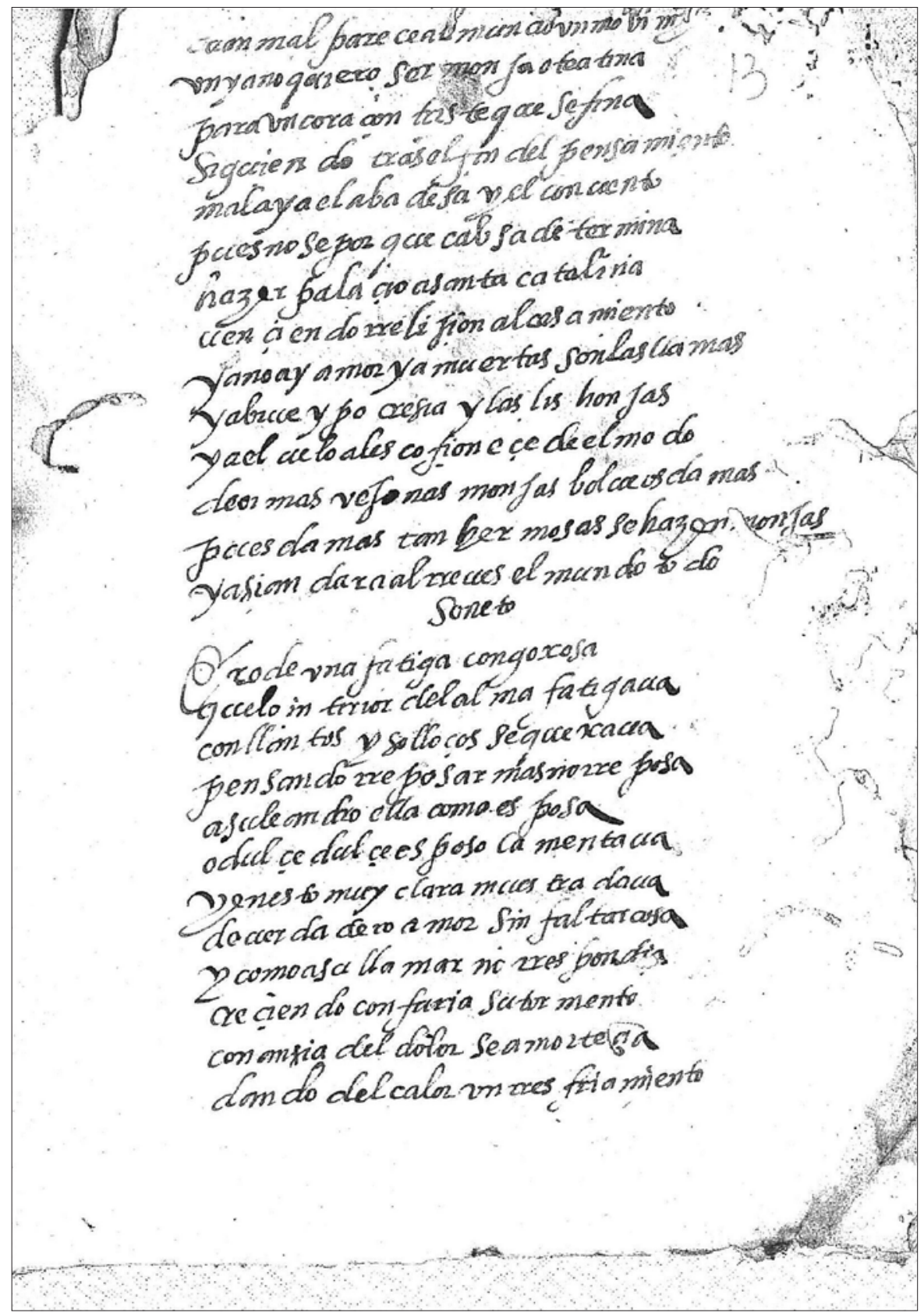




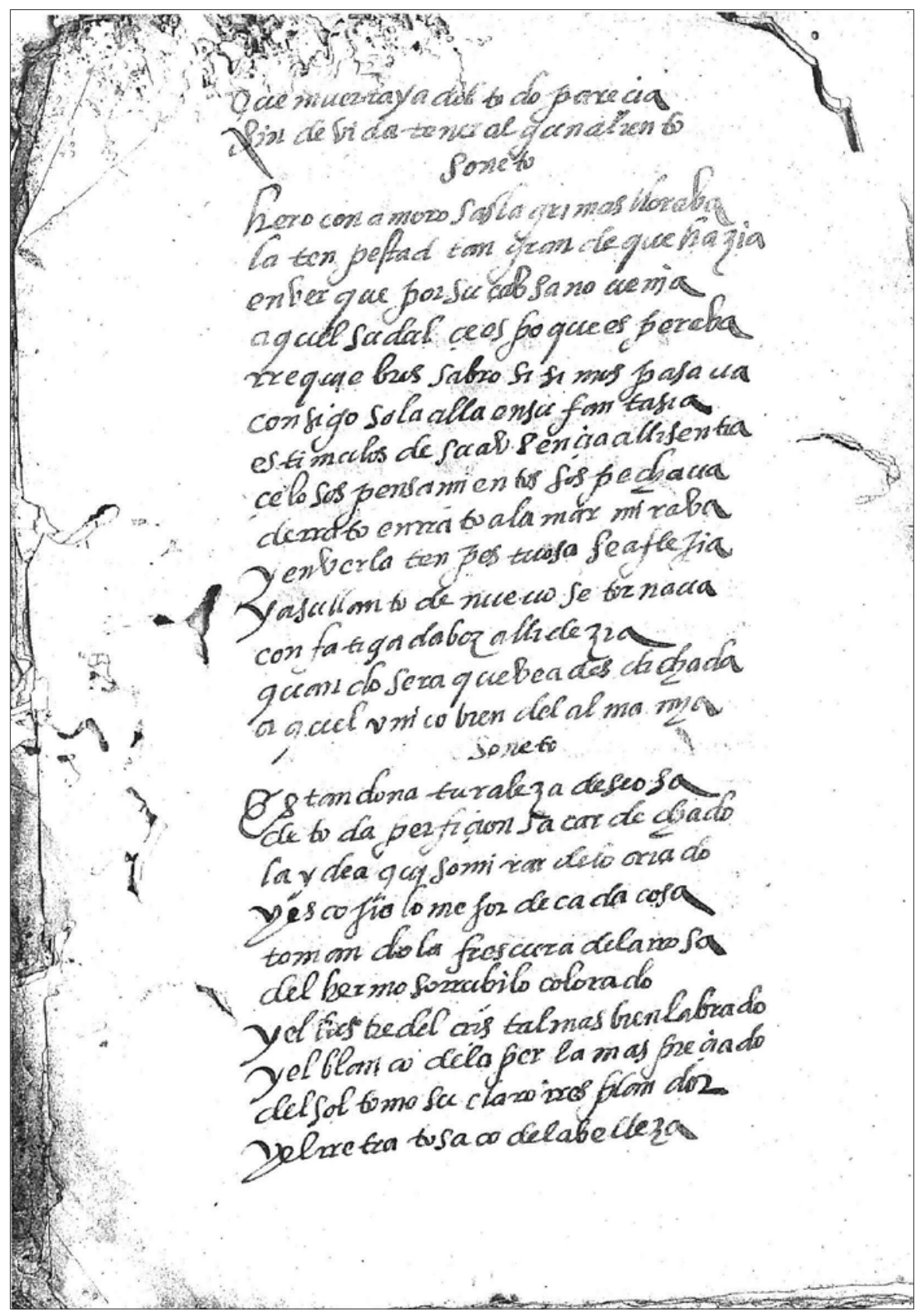




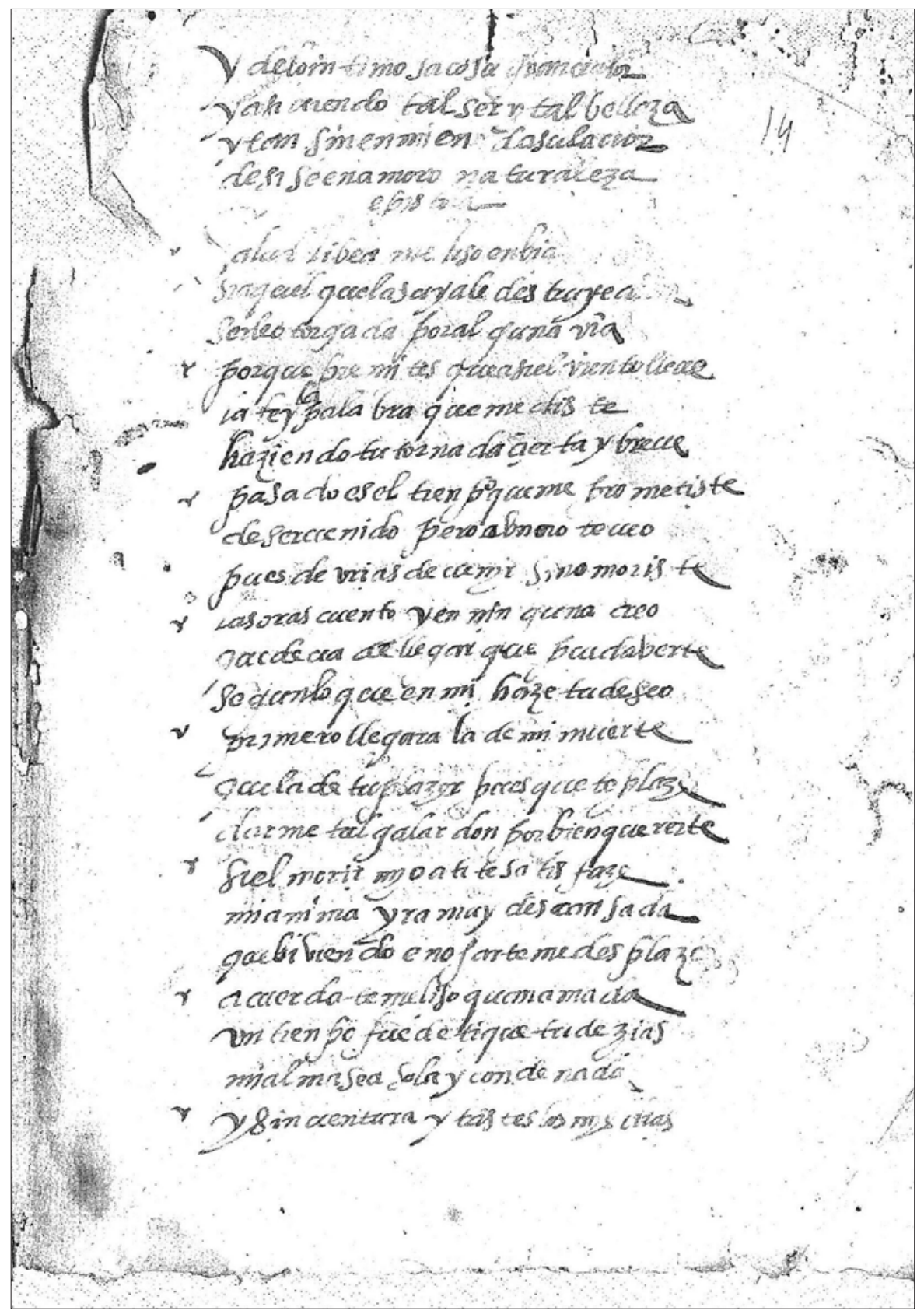




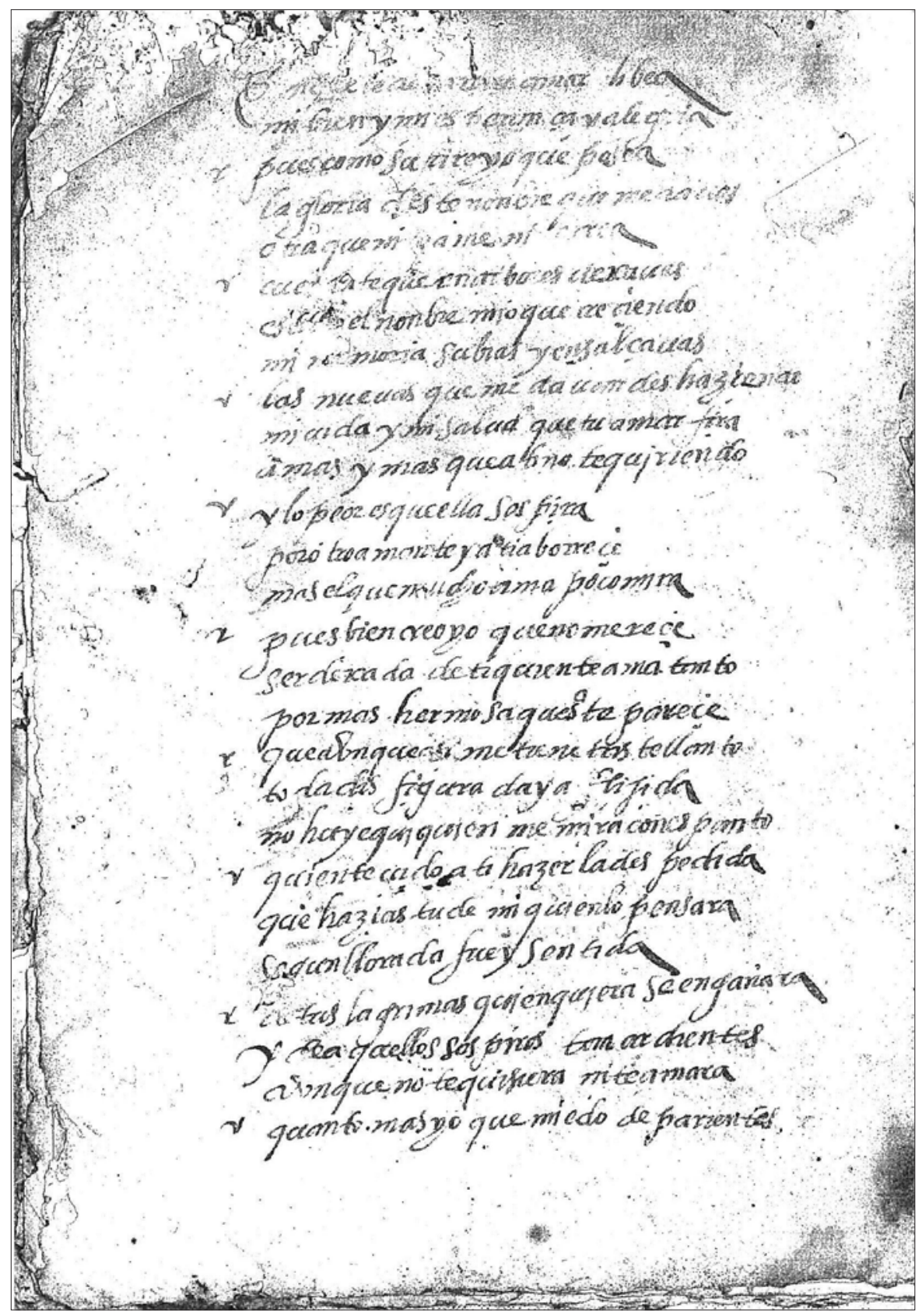




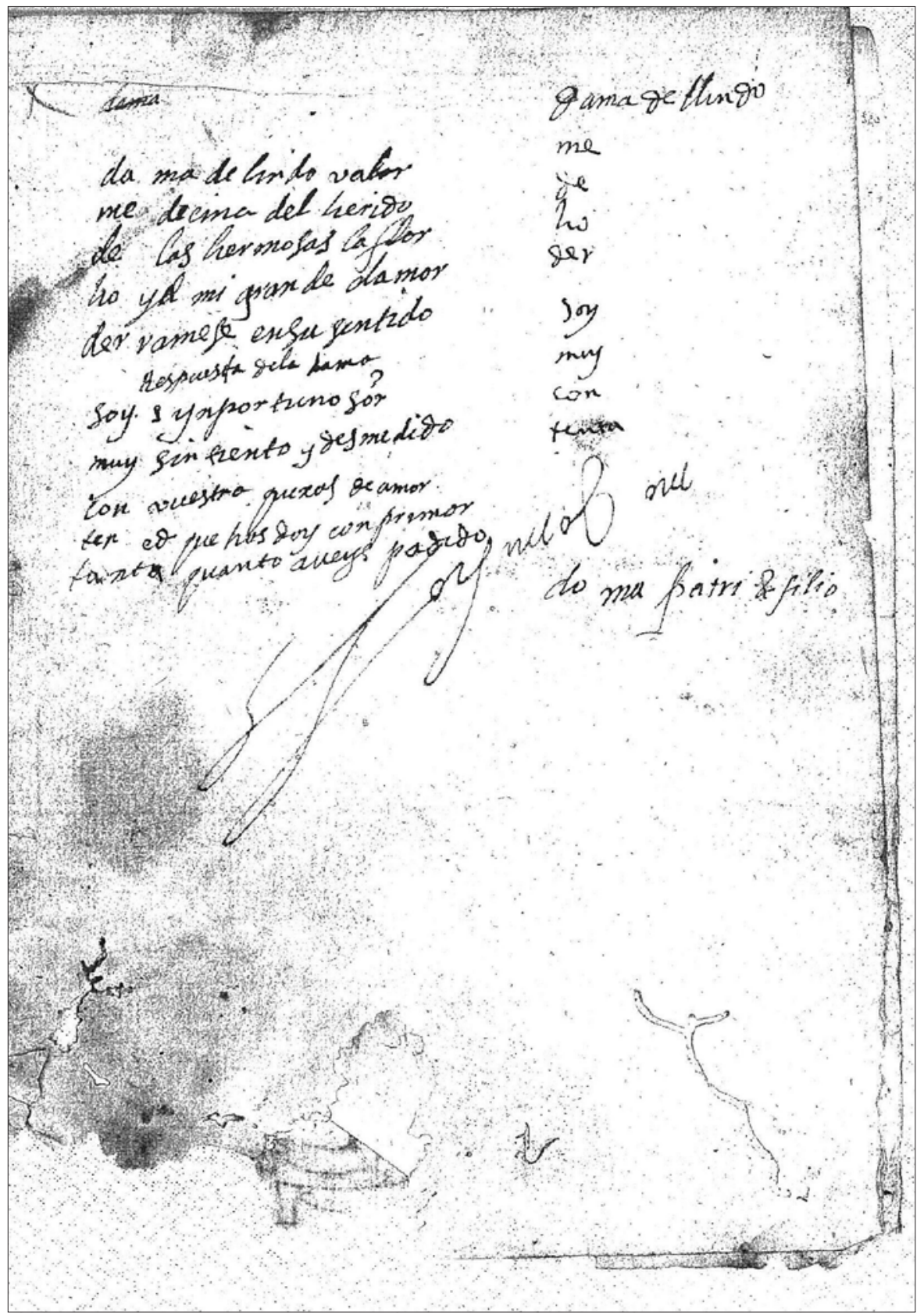




\section{Apéndice II}

ROMANCES VETEROTESTAMENTARIOS AFINES A LA TEMÁTICA DE LOS ROMANCES BÍBLICOS CONTENIDOS EN EL CUADERNO DE VERSOS, procedentes del pliego suelto, Aqui comiençan seys romances. Sign. R 261850, BNC, fol. 2r-2v, y de Lorenzo de Sepúlveda, Cancionero de romances (1576 Medina del Campo), fol. 269r$269 \mathrm{v}$. Se reproduce a continuación el texto según la lectura de la primera fuente, sin reconstrucción y corrección alguna:

Romance del rey Saúl.

Quando murio el rey saul y jonatas su hijo amado quando el pueblo de Israel fue todo desbaratado a Dauid traxo las nueuas vn hombre desuenturado hablole con cortesia como hombre muy bien criado nueuas te traygo seńor de lo que agora ha passado en los montes de Gelboe acaso yo me he hallado via Saul sobre su espada que estaua muy congoxado dixo me que le matasse por no morir tan penado viendo le penar señor acabe lo començado puse me sobre su cuerpo del todo quedo finado en señal que queda muerto su corona le ha quitado Dauid quando aquesto oyera sus vestidos ha rasgado al que las nueuas le traxo su nombre le ha preguntado en confessando donde era mando fuesse degollado por poner manos en rey que era vngido y consagrado a todos manda Dauid que alcen llanto sobrado el primero que comi[e]nça el rey Dauid es llamado

Otro del mismo Israel mira tus montes 


como estan ensangrentados
de la sangre de tus nobles
caualleros esforçados
ay dolor como cayeron
varones tan señalados
no sepan en Philistea
de casos tan desdichados
ni se alegren las mugeres
de los incircuncidados
llorad hijas de Israel
y teńid vuestros tocados
pues es muerto el rey Saul
que os daua pańos labrados
o montes de Gelboe
malditos seays llamados
el cielo os quite el rocio
no llueua en vuestros collados
no lleue dios mas primicias
de todos vuestros sembrados
do fueron muertos los nobles
y sus escudos quebrados
donde murio el rey Saul
rey de reyes señalado97
y el rey Jonatas su hijo
varones no acouardados
como aguilas ligeros
como leones osados
los golpes de sus espadas
no fueron mal empleados
o Jonatas grande amigo
y entre todos señalado
duelo me de la tu muerte
y de la de tus criados
con amor de dos hermanos
eramos yo y tu criados
o perra cruel fortuna
como al mal le busca cabo.

como estan ensangrentados

de la sangre de tus nobles

caualleros esforçados

ay dolor como cayeron

varones tan seńalados

no sepan en Philistea

de casos tan desdichados

ni se alegren las mugeres

de los incircuncidados

Sepúlveda asimismo incluye los siguientes cuatro romances bíblicos además de estos dos últimos (ff. 269r-269v y 269v-270v): Romance de Iudith y Olofernes, ff. 196r-198v; Romance de Dauid y Golias, ff. 199r-200v; Romance de Dauid y Bersabe, ff. 200v-202r; Romance de Josue, ff. 202r-203r. Se reproducen a continuación:

97. Probable indicación léxica, aunque basada en el superlativo en hebreo, de una interpretación cristológica, neotestamentaria, de la historia veterotestamentaria.

98. $[$ sic $]$. 
Romance de Iudith y Olofernes.

El gran Nabucdonosor

rey de la Siria nombrado

poderoso es y muy rico

en guerras bien fortunado

por los reyes que ha vencido

gran soberuia auia cobrado

acordo de someter

todo el mundo a su reynado

a Olofernes capitan

luego le auia mandado

que con mucha gente de armas

vaya a todos guerreando

y no perdona a ninguno

si no se diere a su mando

obedeciera Olofernes

lo quel rey le auia mandado

muy grandes reynos gano

por fuerça otros de grado

sobre el pueblo de Israel

muy feroz auia llegado

los del pueblo que lo vieron

muy gran temor han cobrado

sobre Bitulia ciudad

su real tiene assentado

el agua luego les quita

tiene los muy apremiados

los de dentro a grandes gritos

a su Dios estan rogando

que dellos quiera acordarse

y no los aya oluidado

y con muy crecido esfuerço

todos han determinado

de salir al campo juntos

y morir o ser librados

Ozias su sacerdote

los detiene y a rogado

que aguardassen cinco dias sin salir al campo armados

y que si dentro de aquestos

su Dios no los ha librado

que hagan su voluntad

y lo que han acordado

Iudich essa hermosa y casta

muger de esfuerço loado

despues de auer entendido

lo que Ozias ha hablado

al su pueblo reprehende

mucho los ha denostado 
dixo, Que no es buen consejo

el que les ouiera dado

en poner termino a Dios

para los hazer librados

antes auran dado causa

contra si en auerlo ayrado

dixoles, Pidan perdon

todos del yerro passado

a todos juntos les ruega

con gran fee les ha encargado

que ruegen a Dios del cielo

que la tenga de su mano

y que ella quitara el cerco

que de Betulia es cercado

o morir en la demanda

como varon esforçado

y con este presupuesto

el camino auia tomado

de donde estaua el real

de Olofernes el tirano

En saliendo de Betulia

las guardas la auian tomado

preguntaronle donde era

o a quien lleuaua recado

respondio que era judio

y que con muy gran quebranto

se salio de la ciudad

por no ver lloro tan alto

como lo haran los de dentro

quando todos sean tomados

y que de mas desto quiere

que Olofernes sea auisado

por donde luego la tome

sin peligro de su estado

Olofernes que la vido quedo della enamorado

Iudich le dixo a Olofernes

lo que tenemos contado

Olofernes le rogo

que sea su combidado

respondierale Iudich

que haria gran peccado

porque no son de una ley

que su ley lo auie uedado

solamente le suplica

en merced la aya dado

que la dexasse salir

a orar lo acostumbrado

que acabada la oracion 
para el se auria tornado

Olofernes concedio

lo que ella le ha demandado

y mando a todas sus gentes

como señor superado

que de dia ni de noche

a Iudich pongan embargo

de entrar y salir tanbien

en el real a su grado

$\mathrm{Al}$ quarto dia que Iudich

a Olofernes ha llegado

mando hazer una cena

de valor muy estimado

y a un Eunuco que tenia

aquello le auia mandado

que hable luego con ella

para que la aya a su mando

y que duerma aquella noche

en su cama y a su lado

Iudich que lo auia sabido

luego lo auia aceptado

presentose ante Olofernes

hermosa en estremo grado

y mas galana que nunca

ante el le auia mostrado

cenan con mucha alegria

con plazer y gasajado

Olofernes se acosto

el primero y mas temprano

el qual luego se durmio

aunque estaua embriagado

la puerta cerro Iudich

como muger de recaudo

y quando vido a Olofernes

como esta tan descuydado

a su Dios hizo oracion

y esto le ha suplicado

que le de gracia que pueda

hazer su pueblo librado

y el espada de Olofernes

ella la toma en su mano

y con ella a Olofernes

la cabeça le ha cortado

metierala en una cesta

y a su criada la ha dado

juntas salen del real

ninguno lo ha vedado

de los que estauan en el

porque ansi les fue mandado 


$$
\begin{aligned}
& \text { y con plazer muy crecido } \\
& \text { a Betulia auia tornado } \\
& \text { y la cabeça que traya } \\
& \text { a todos la auia mostrado } \\
& \text { todos cobran coraçon } \\
& \text { contra los Asirianos } \\
& \text { gran matança hazen dellos } \\
& \text { do quedaron bien vengados } \\
& \text { de los daños recibidos } \\
& \text { del Capitan ya nombrado } \\
& \text { porque Iudich fue tan buena } \\
& \text { en el caso ya contado } \\
& \text { que por ella se libraron } \\
& \text { de Olofernes el tyranno. }
\end{aligned}
$$

Romance de Dauid y Golias Gran guerra tiene Saul muy sangrienta es la batalla con aquestos Philisteos gente a su reyno cercaua pelean como valientes unos a otros se matan a todos Saul vencia los contrarios desmayauan ayudar los Philisteos un gran gigante llegaua Golias auia por nombre de catadura muy braua de desmesura fuerça a todos heria y mataua tan valiente es que a diez mil venceria en la batalla Los Iudios que lo vieron con su vista desmayauan cobraron gran couardia de su catadura mala huyendo yuan de antel que ninguno lo aguardaua en el real estan todos no salen a la batalla en el real de Saul tres hermanos guerreauan hijos eran de Esayas hermanos de Dauid se llaman alli estaua el buen Dauid que su padre lo mandaua para visitar sus hijos prouision les embiaua, estando alli todos juntos 
oyeron pregon que dauan

por mandado de Saul,

lo siguiente declaraua,

Que si cauallero vuiesse

que saliesse a la batalla

con Golias gran gigante

gran cosa le seria dada

y si en ella lo venciesse

hermosa muger cobrara

a Michal sola su hija

que es hermosa y agraciada

con la mitad del su reyno

lo qual todo le otorgaua

Estando dando el pregon

los Iudios desmayauan,

huyendo van de Golias

que a todos heria y mataua

Dauid que huyr los vido

sabida por el la causa

quedo muy marauillado

de su couardia tanta,

fuera luego ante Saul

licencia le demandaua

para lidiar con Golias

el que a todos assombraua

dixo al rey que no temiesse

de hazer lo que demanda

que un osso y leon he muerto

que sus ganados matauan

Quando Saul vio el esfuerço

que el nińo Dauid mostraua

luego lo mando armar

y con sus armas le armaua

con ellas no puede andar

de sobre si las quitaua

tomo su cayado y honda

tres piedras Dauid tomaua

(70)

metidas en su çurron

que puesto al cuello lleuaua

fue donde estaua el Gigante

a començar la batalla.

Golias quando lo vido

esta pregunta le daua

Soy yo perro por ventura

que vienes con tales armas?

No solo traygo el cayado

el niño le replicaua

para yo lidiar contigo.

mas el Dios que yo adoraua 
con su nombre vencere

esta tu persona braua

cortarte yo tu cabeça

con essa tu propia espada

luego tomara una piedra

de aquellas tres que lleuaua

en la honda la ponia

a Golias la tiraua

diole en la frente con ella

del golpe lo derribaua

fue sobre el denodado

su cuchillo le tomaua

cortole la su cabeça

por las baruas la tomaua

boluiose para el real

a Saul le presentaua

recibio muy gran plazer

con su hija lo casaua.

Romance de Dauid y Bersabe El rey a modo de Dios

ques Dauid el muy nombrado cruel guerra ha con Amon

al su reyno muy llegado

a su capitan Ioab

contra Amon lo auia embiado

el quedo en Hierusalem

cabeça de su reynado

el amor como es tan ciego

o que mal que lo ha engańado

passeandose esta Dauid

un dia por su palacio

desde unos corredores

Bersabe se auie mostrado

casado era con Urias,

Urias Eteo llamado

en el real de Dauid

esta el cauallero honrado

la qual era muy hermosa

graciosa en estremo grado

junto estaua de una fuente

lauandose el su tocado

luego que Dauid la vido

quedo della enamorado

embio luego por ella

fue trayda al su palacio

y sin ninguna tardança

con ella se auia mezclado

no solamente esta vez 
otras muchas lo auia usado

empreñose Bersabe

de Dauid se auia empreñado

a Ioab su capitan

en secreto auia mandado

que a Urias buen cauallero

ante todos se ha parado

al tiempo del combatir

algun pueblo seńalado,

de manera que lo maten

y no pueda ser librado

lo que Dauid le mando

Ioab lo tiene ordenado

que combatiendo a Rabat

muerto fuera el no culpado

sabido lo ha Dauid

con Bersabe se ha casado,

Natham propheta de Dios

a Dauid ha preguntado

dixole, Un hombre rico

tenia mucho ganado,

un pobre vezino suyo

una oueja por rebaño,

y el rico se la tomo

con el coraçon dañado

no contento con el robo

al pobre auia matado

respondeme rey Dauid

que pena tendra el culpado?

respondio Dauid, Que es digno

de muerte por tal peccado,

Respondio Natham, O rey

tu eres el condenado,

tu Dauid eres el rico,

Urias pobre cuytado

tu tenias muchas mugeres

el una sola en su cabo

a Bersabe le tomaste

con ella ya eres casado

no siendo contento dello

muerto fue por tu mandado,

de parte de Dios te anuncio

maldicion por tu peccado

Quando esto oyo Dauid

con gemidos ha llorado

siete dias con sus noches

retraydo en apartado

muy gran penitencia ha hecho

de Dios quedo perdonado. 
Otro Romance de Iosue.

Oran que era rey de Hebron y otros reyes comarcanos juntado se han en uno con muchos hombres armados para contra los Iudios que en Gabaon son llegados ponen en campo sus gentes \& varones esforçados a Gabaon combatian los varones afamados Los Iudios que estan dentro su mensaje han embiado a Iosue capitan con quien son confederados para que a socorrerlos venga y hazerlos librados Iosue que vio el mensaje en oracion se auie echado Dios dixo que auria victoria contra estos sus contrarios todas sus gentes tomo a Gabaon son llegados guerrea los Amoreos gran batalla les ha dado muchos mata muchos prende muy mal quedan lastimados los vencidos van huyendo en ellos yuan matando sobre los que dellos huyen Dios mostro los sus miraglos sobre ellos cayo granizo los muertos cubren los campos ya hora era de sexta Iosue siempre matando en todos los enemigos el dia se yua acabando con la gran fe que tenia al sol y luna ha mandado que esten en su resplandor $\&$ no anden lo acostumbrado al sol hazia Gabaon ni luna a Aialon collado pararonse el sol \& luna no se mouieron de un cabo siempre esta resplandeciente hasta muertos los contrarios por la muy gran fe que tuuo la victoria auia alcançado. 


\section{Bibliografía}

Alatorre, Antonio, «Los romances de Hero y Leandro», Libro jubilar de Alfonso Reyes, México, D.F., Universidad Nacional. Dirección General de Difusión Cultural, 1956, 1-46.

—, «Fortuna varia de un chiste gongorino", NRFH, XV, 1961, 483-504.

—, "Sobre la 'gran fortuna' de un soneto de Garcilaso», Nueva Revista de Filología Hispánica, XXIV (1975), 142-177.

Anónimo, Simbolos de España, Madrid, Centro de Estudios Políticos y Constitucionales, 2000. Wikipedia, dirección electrónica http://es.wikipedia.org/ wiki/Escudo_de_espa\%C3\%B1a, consultado el 23/4/2012.

—, «Las armas reales de España», dirección electrónica http:www.heraldicahispanica.coméArmasR.htm

—, Aqui comiençan seis romances, pliego suelto, s.d., s.l., Sign. R. 261850, BNC.

Arellano, Ignacio, y Jesús Cañedo, eds., Crítica textual y anotación filológica en obras del Siglo de Oro, Madrid, Castalia, 1991.

Badia I Cardús, Montserrat, Introducció a la fonètica $i$ a la fonologia catalanes, Barcelona, Curial / Edicions Catalanes, Publicacions de l'Abadia de Montserrat, 2002, 222.

Biblia Hebreo-Español, La, versión castellana a cargo de Moisés Katznelson, 2 vols., Tel-Aviv, Editorial Sinaí, 1996.

Blecua, Alberto. Manual de crítica textual, Madrid, Castalia, 1990.

Blecua, José Manuel, Poesía de la Edad de Oro, 2 tomos, t. I Renacimiento, 1982; t. II Barroco, 1984, Madrid, Castalia.

Bohias, Pere, «Normes per a la descripció codicològica dels manuscrits», Biblioteconomía, no. 77-78 (1973-74), 93-99.

Boscán, Juan y Garcilaso de la VeGA, La obras de Boscán y algunos poemas de Garcilaso de la Vega: repartidos en cuatro libros, Barcelona, Carles Amorós, 1545. http://www.cervantesvirtual.com/

Boscán, Joan, Obras, ed. Carlos Clavería, Barcelona, PPU, 1991.

Briquet, C. M., Les Filigranes. Dictionnaire Historique des Marques du Papier dès leur apparition vers 1282 jusquien 1600, 4 tomos, 2a ed., New York, Hacker Art Books, 1966.

Brown, Kenneth, "Context i text del Vexamen d'Acadèmia de Francesc Fontanella», Llengua \& Literatura, 2, 1987, 173-252.

Camprubí , Francesc, y Anglés, Pere Màrtir, Lumen domus o Annals del Convent de Santa Caterina Verge i Màrtir de Barcelona, Orde de Predicadors, Barcelona, 1743, tomo II, pp. 246-247, BUB, mss. 1005-1007.

Cancionero llamado Flor de enamorados (Barcelona 1562), ed. Antonio Rodríguez-Moñino y Daniel Devoto, Valencia, Castalia, 1954.

Cancionero sevillano de Toledo: manuscrito 506 (fondo Borbón-Lorenzana), Biblioteca de Castilla-La Mancha, eds. José J. Labrador, Ralph DiFranco, Juan Montero, Sevilla, Universidad de Sevilla, 2006. 
Cantera Burgos, Francisco, «El Cancionero de Baena: judíos y conversos en él», Sefarad, XXVII (1967), 71-111.

—, «Los repartimientos de Rabí Jaco Aben Nuñes», Sefarad, 31.2 (1971), 213247.

Carson, Thomas, y Joann Cerrito, eds., New Catholic Encyclopedia, 2a ed., 15 vols. y 4 suplementos, aquí vol. 9, Detroit, New York, San Diego, San Francisco, Cleveland, New Haven, Waterville, London, Munich, Thomson - Gale, The Catholic University of America, 2003.

Cazeneuve i Descarrega, Xavier, "La llengua en la documentació notarial de la Barcelona de 1700", en Albert Garcia Espuche, Director, Llengua i literatura. Barcelona 1700, Col-lecció La Ciutat del Born . Barcelona I700, Barcelona, Ajuntament de Barcelona y l'Institut de Cultura, 2011, 102-153.

Cetina, Gutierra de, Obras de ..., ed. Joaquín Hazañas y la Rúa, México, Porrúa, 1977.

—, Rimas, ed. Jesús Ponce Cárdenas, Madrid, Cátedra, 2014.

- Sonetos y madrigales completos, ed. Begoña López Bueno, Madrid, Cátedra, 1981 y 1990.

Churchill, W. A., Watermarks in Paper in Holland, England, France, etc., in the XVIIth and XVIIIth Centuries and their Interconnection, Amsterdam, Menno Hertzberger \& Co., (1965) [orig. 1935].

Cossío, J.M., «Sobre la transmisión del tema de Hero y Leandro», RFE, 16 (1929), 174-175.

—, Fábulas mitológicas en España, Madrid, Espasa-Calpe, 1952.

Darst, David H., Don Diego Hurtado de Mendoza, Boston, Twayne, 1987.

DíAz-Mas, Paloma, "El tema de José en la literatura hispanojudía y sefardí», en Revista de estudios hispánicos de Kioto, Kioto, Japón, Asociación de Licenciados, Departamento de Estudios Hispánicos, Universidad de Estudios Extranjeros de Kioto, 1997, 25-36.

Díez Fernández, José Ignacio, «Hurtado de Mendoza, Diego», Ed. Pablo Jauralde Pou, Diccionario Filológico de literatura española siglo XVI, Coor. Delia Gavela y Pedro C. Rojo Alique, Madrid, Castalia, 2009, 509-525.

Domínguez Ortiz, Antonio, Desde Carlos V a la Paz de los Pirineos 1517-1660, Barcelona, Buenos Aires, México, D.F., Ediciones Grijalbo, 1974.

Encyclop edia Britannica, Inc., The New Encyclopedia Britanica, 32 vols.,

15a ed., Chicago / London / New Delhi / Paris / Seoul / Sydney / Taipei / Tokyo, 2002.

Enciclopaedia Judaica, eds. generales Cecil Roth y Geoffrey Wigoder, 16 vols., Jerusalem, Keter Publishing House y The Macmillan Company, 1971.

Entenza de Solare, Beatriz, ed., Poesías varias (Ms. 1132 de la Biblioteca Nacional de Madrid), Buenos Aires, Universidad de Buenos Aires, Facultad de Filosofía y Letras, 1978.

FARNÉS I Julià, Soledat, "Alguns manuscrits de medicina i ciències a fins dels 
segles XV i XVI a Catalunya", Actes IV Congrés d'Història de la Medicina Catalana (Poblet 7-9 de juny de 1985), III, 141-147.

Fernández Álvarez, Manuel, Carlos V, el César y el hombre, Madrid, Espasa Calpe, 1999.

—, Carlos V: Un hombre para Europa, Madrid, Ediciones Cultura Hispánica, 1976.

Fuentes, Alonso de, Quarenta cantos de diversas y peregrinas historias, declarados y moralizados, por el magnifico cavallero Alonso de Fuentes, Sevilla, Dominico de Robertis, difuncto, 4 abril de 1550, in- $4^{\circ}$, 238 ff.

Gallego Morell, Antonio, Estudios sobre poesía del primer siglo de oro, Madrid, Ínsula, 1970.

GarCia, Vicent, La armonia del Parnàs, més numerosa en las poesies varias del Atlant del cel poètic, Lo Dr Vicent Garcia, de Santa Maria de Vallfogona. Recopiladas y emendadas por dos ingenis de la molt il.lustre Acadèmia dels Desconfiats, Barcelona, Rafel Figueró, 1703, BUB, sign. B64/4/18.

Garçón, T., El teatro de ingenios, Barcelona 1600 [Ejemplar de la Biblioteca Provincial Madrid].

Girón-Negrón, Luis M., y Laura Minervini, LAS Coplas DE Yosef. Entre la biblia y el midrash en la poesía judeoespañola, Madrid, Gredos, 2006.

González Palencia, Ángel, ed., El Cancionero del poeta George de Montemayor, Madrid, 1932.

Góngora, Luis de, Romances, ed. Antonio Carreño, Madrid, Cátedra, 2000.

Guillén, Claudio, El primer siglo de oro: estudios sobre géneros y modelos, Barcelona, Crítica, 1988.

Gutwirth, Eleazar, «Coplas de Yocef” from the Genizah», Revue des Études Juives, 155, 1996, no. 3-4, 387-400.

Herrera, Fernando de, Obras de Garci Lasso de la Vega con anotaciones de Fernando de Herrera (Sevilla, Alonso de la Barrera, 1580), ed. facsímil, 2 tomos, estudio bibiliográfico por Juan Montero, Córdoba / Huelva / Sevilla, Universidad de Córdoba, Universidad de Huelva, Universidad de Sevilla, Grupo P.A.S.O., 1998.

Hurtado de Mendoza, Diego, Poesía completa, ed. J. Ignacio Díez Fernández, Sevilla, Fundación José Manuel Lara, 2007.

—, Poesía. Luis F. Díaz Larios y Olga Gete Carpio, eds., Madrid, Cátedra, 1990.

Ife, B. W., ed., Dos versiones de Piramo y Tisbe: Jorge de Montemayor y Pedro Sánchez de Viana, Exeter, University of Exeter, 1974.

Jauralde Pou, Pablo, Diccionario Filológico de Literatura Española siglo XVI, Coor. Delia Gavela y Pedro C. Rojo Alique, Madrid, Castalia, 2009.

Kazhdan, Alexander, ed., Oxford Dictionary of Byzantium, Oxford, Oxford University Press, 1991, 815.

LAPESA, Rafael, Garcilaso: Estudios completos. La trayectoria poética de Garcilaso, Madrid, Istmo, 1985.

Lázaro Carreter, Fernando, «Situación de la Fábula de Píramo y Tisbe», NRFH, XV, 1961, 463-482. 
Lucano, Marco Anneo, autor, y Martín Lasso de Oropesa, traductor, La historia que escriuió en latín el poeta Lucano / Pharsalia, Madrid [?], 1530.

Madurell Marimón, José. Índice cronológico alfabético [de los protocolos, manuales y demás documentos], 3 volúmenes in totum, III. Siglos XVIII. Varia. Barcelona: Colegio Notarial de Barcelona, (1950-59). Vol. I. Siglos XIII-XVI. 1950; II. Siglo XVII. 1953; III. Siglo XVIII; Apéndice: Siglos XIV-XVIII, Regesta: Siglo XIX; Escribanias de Marina: Siglos XVIII-XIX; Notarias Foráneas: Siglos XIII-XVI; Pergaminos: Siglos XIII-XVI; Escribanias Varias; Miscelánea; Varia.

Mateu Ibars, Josefina, «Manuscrits de «ars medica» en la Biblioteca General de la Universitat de Barcelona: Referència catalogràfica s. XVII-XIX", Gimbernat: revista catalana d'història de la medicina i de la ciència, Any 1998, 30, 207-236.

—, «Incunables de "Ars Medica» en la Biblioteca de la Universitat de Barcelona», Gimbernat, 1993, XIX, 197-216.

—, "Manuscrits de Medicina i Ciències afins a la Biblioteca Provincial i Universitària de Barcelona, Actes III Congrés d'História de la Medicina Catalana, Lleida, 1981, II, 187-203.

Messía de la Cerda y Pita, Luis F., Heráldica española, Madrid, Aldaba, 1990

Millares Carlo, Agustín, con la colaboración de José Manuel Ruiz Asencio, Tratado de paleografía española, 3 vols., Madrid, Espasa-Calpe, 1983 [orig. 1929].

Montemayor, Jorge de, Poesía completa: CANCIONERO (I 554 ), CANCIONERO (I 562 ), SEGUNDO CANCIONERO

( 155 8), Traducción de los Cantos de Amor de Ausias March, eds. Juan Bautista Avalle-Arce y Manuel Arroyo Stephens, Madrid, Turner Libros, 1996.

—, Poesía selecta, ed. Juan Montero y Elizabeth Rhodes, Madrid, Clásicos Castalia, 2012.

NÁGera, Esteban de, Cancionero general de obras nuevas (Zaragoza 1556), ed. Carlos Clavería, Barcelona, Edicions Delstre's, 1993, 247-264.

Orduna, Germán. Ecdótica: Problemática de la edición de textos, Kassel, Edition Reichenberger, 2000.

Pardo de Guevara y Valdés, Eduardo, Manual de heráldica española, Madrid, Aldaba, 1987.

Pedraza, Felipe B. y Milagros Rodríguez, Manual de literatura española, Pamplona, Cénlit, 1980.

Pérez Priego, Miguel Ángel, La edición de textos, Madrid, Síntesis, 1997.

Prieto, Antonio, La poesía española del siglo XVI, 2 vols., I, Madrid, Cátedra, 1984.

Rico García, J. Manuel, «Cetina, Gutierre de», Ed. Pablo Jauralde Pou, Diccionario Filológico de literatura española siglo XVI, Coor. Delia Gavela y Pedro C. Rojo Alique, Madrid, Castalia, 2009, 237-256.

Riquer, Martín de, Manual de heráldica española, Barcelona, Editorial Apolo, 1942.

Rivers, Elias L., Boscán y Garcilaso: su amistad y el renacimiento en España, Sevilla, Sibilina, 2010 
Rodríguez-Moñino, Antonio, La Silva de Romances de Barcelona, 1561, Salamanca, Universidad de Salamanca, 1969.

—, Nuevo diccionario bibliográfico de pliegos sueltos poéticos (siglo XVI), ed. corregida y actualizada por Arthur L-F. Askins y Víctor Infantes, Madrid, Castalia, Mérida, Editora Regional de Extremadura, 1997.

Rojo Alique, Pedro C., Mercedes Sánchez Sánchez, Elena Varela Merino, Universidad Autónoma de Madrid (Edad de Oro), Catálogo de manuscritos de la Biblioteca Nacional con poesía en castellano de los siglos XVI y XVII, 7 vols., V, Índices vols. I-IV, Madrid, Arco Libros, (1998-2007 para la serie), 1998.

RuaIX I VINYET, Josep, Català en fitxes, III vols., Editorial Ruaix, Moià, 1983.

SepúlVEDA, Lorenzo de, recopilador, Cancionero de romances nuevamente sacados de historias antiguas de la crónica de España y algunos sacados de los quarenta cantos que compuso A. de Fuentes, Medina del Campo, por Francisco del Canto, a costa del mercader de libros Benito Boyer, 1576

-, Cancionero de romances (Sevilla, 1584), ed. Antonio Rodríguez-Moñino, Madrid, Castalia, 1967.

Schwegler, Armin, Juergen Kempff y Ana Ameal-Guerra, Fonética y fonología españolas, $4^{\mathrm{a}}$ ed., New Jersey, John Wiley \& Sons, Inc., 2010.

Sepúlveda, Lorenzo de, Cancionero de romances, Medina del Campo, 1576 [ejemplar consultado, el de la Stadbibliothek Ulm].

-, Cancionero de romances (Sevilla, 1580), ed. Antonio Rodríguez-Moñino, Madrid, Castalia, 1968.

Silva de varios romances, Barcelona, Jayme Cortey, 1561, ed. Antonio Rodríguez -Moñino, Valencia, Castalia, 1953.

TabladA, Juan José, «El enigma de Gutierre de Cetina», http://www.tablada. unam.mx/poesia/ensayos/enigma.html. Consultado 28/09/2014.

Terry, Arthur, ed., An Anthology of Spanish Poetry 1500-1700 Part I 1500-1580, Oxford London · Edinburgh · New York · Paris · Frankfurt, Pergamon Press Ltd., 1965.

Torre, Lucas de, «Algunas notas para la biografía de Gutierre de Cetina, seguida de varias composiciones suyas inéditas», Boletin de la Real Academia Española, 11 (1924), pp. 388-407, 601-626.

The Torah: A Modern Commentary, ed. W. Gunther Plaut, New York, URJ Press, 2006, 454-455.

VAlls I SubIRÀ, Oriol, Paper and Watermarks in Catalonia / El papel y sus filigranas en Catalunya, 2 vols., Amsterdam, The Paper Publications Society, 1970.

VegA, Garcilaso de la, Obra poética y textos en prosa, ed. Bienvenido Morros, Barcelona, Crítica, 1995.

Vega, Garcilaso de la, Poesía castellana completa, ed. Elias L. Rivers, Madrid, Castalia, 1996. 